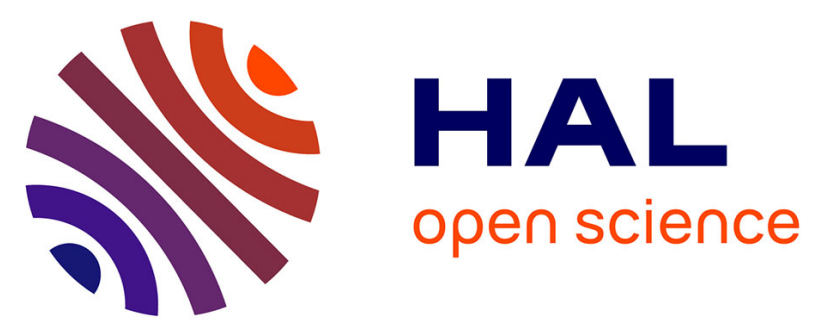

\title{
Magmatic and hydrothermal behavior of uranium in syntectonic leucogranites: The uranium mineralization associated with the Hercynian Grande granite (Armorican Massif, France)
}

\author{
Christophe Ballouard, Marc Poujol, Philippe Boulvais, Julien Mercadier, \\ Romain Tartese, Torsten Vennemann, Etienne Deloule, Marc Jolivet, Inoussa \\ Kéré, Michel Cathelineau, et al.
}

\section{- To cite this version:}

Christophe Ballouard, Marc Poujol, Philippe Boulvais, Julien Mercadier, Romain Tartese, et al.. Magmatic and hydrothermal behavior of uranium in syntectonic leucogranites: The uranium mineralization associated with the Hercynian Grande granite (Armorican Massif, France). Ore Geology Reviews, 2017, 80, pp.309-331. 10.1016/j.oregeorev.2016.06.034 . insu-01342001

\section{HAL Id: insu-01342001 https://hal-insu.archives-ouvertes.fr/insu-01342001}

Submitted on 5 Jul 2016

HAL is a multi-disciplinary open access archive for the deposit and dissemination of scientific research documents, whether they are published or not. The documents may come from teaching and research institutions in France or abroad, or from public or private research centers.
L'archive ouverte pluridisciplinaire HAL, est destinée au dépôt et à la diffusion de documents scientifiques de niveau recherche, publiés ou non, émanant des établissements d'enseignement et de recherche français ou étrangers, des laboratoires publics ou privés. 


\section{Accepted Manuscript}

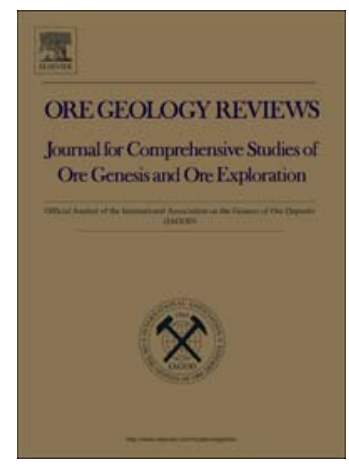

Magmatic and hydrothermal behavior of uranium in syntectonic leucogranites: The uranium mineralization associated with the Hercynian Guérande granite (Armorican Massif, France)

C. Ballouard, M. Poujol, P. Boulvais, J. Mercadier, R. Tartèse, T. Venneman, E. Deloule, M. Jolivet, I. Kéré, M. Cathelineau, M. Cuney

PII: $\quad$ S0169-1368(16)30372-9

DOI: $\quad$ doi: $10.1016 /$ j.oregeorev.2016.06.034

Reference: $\quad$ OREGEO 1862

To appear in: $\quad$ Ore Geology Reviews

Please cite this article as: Ballouard, C., Poujol, M., Boulvais, P., Mercadier, J., Tartèse, R., Venneman, T., Deloule, E., Jolivet, M., Kéré, I., Cathelineau, M., Cuney, M., Magmatic and hydrothermal behavior of uranium in syntectonic leucogranites: The uranium mineralization associated with the Hercynian Guérande granite (Armorican Massif, France), Ore Geology Reviews (2016), doi: 10.1016/j.oregeorev.2016.06.034

This is a PDF file of an unedited manuscript that has been accepted for publication. As a service to our customers we are providing this early version of the manuscript. The manuscript will undergo copyediting, typesetting, and review of the resulting proof before it is published in its final form. Please note that during the production process errors may be discovered which could affect the content, and all legal disclaimers that apply to the journal pertain. 


\section{Magmatic and hydrothermal behavior of uranium in syntectonic leucogranites: the uranium mineralization associated with the Hercynian Guérande granite (Armorican Massif, France)}

Ballouard C. ${ }^{1 *}$, Poujol M. ${ }^{1}$, Boulvais $\mathrm{P}^{1}{ }^{1}$, Mercadier J. ${ }^{2}$, Tartèse R. ${ }^{3-4}$, Venneman T. ${ }^{5}$, Deloule E. ${ }^{6}$, Jolivet M. ${ }^{1}$, Kéré, I. ${ }^{1}$, Cathelineau M. ${ }^{2}$, Cuney, M. ${ }^{2}$

${ }^{1}$ UMR CNRS 6118, Géosciences Rennes, OSUR, Université Rennes 1, 35042 Rennes Cedex, France ; *correspondance : christophe.ballouard@univ-rennes1.fr

${ }^{2}$ Université de Lorraine, CNRS, CREGU, GeoRessources, Boulevard des Aiguillettes, BP 70239, 54506 Vandoeuvre-lès-Nancy, France.

${ }^{3}$ Institut de Minéralogie, de Physique des Matériaux et de Cosmochimie, Muséum National d'Histoire Naturelle, Sorbonne Universités, CNRS, UMPC \& IRD, 75005 Paris, France

${ }^{4}$ Department of Physical Sciences, The Open University, Walton Hall, Milton Keynes, MK7 6AA, United Kingdom

${ }^{5}$ Institute of Earth Surface Dynamics, Géopolis, University of Lausanne, CH-1015 Lausanne, Switzerland

${ }^{6}$ CRPG, UMR 7358 CNRS-Université de Lorraine, BP 20, 54501 Vandœuvre cedex, France

Keywords: Hercynian; Peraluminous leucogranites; sub-solidus alteration; uranium deposit.

\section{Abstract:}

Most of the hydrothermal uranium (U) deposits from the European Hercynian belt (EHB) are spatially associated with Carboniferous peraluminous leucogranites. In the southern part of the Armorican Massif (French part of the EHB), the Guérande peraluminous leucogranite was emplaced in an extensional deformation zone at ca. $310 \mathrm{Ma}$ and is spatially associated with several $\mathrm{U}$ deposits and occurrences. The apical zone of the intrusion is structurally located below the Pen $\operatorname{Ar} \operatorname{Ran} U$ deposit, a perigranitic vein-type deposit where mineralization occurs at the contact between black shales and Ordovician acid metavolcanics. In the Métairie-Neuve intragranitic deposit, uranium oxide-quartz veins crosscut the granite and a metasedimentary enclave. 
Airborne radiometric data and published trace element analyses on the Guérande leucogranite suggest significant uranium leaching at the apical zone of the intrusion. The primary $U$ enrichment in the apical zone of the granite likely occurred during both fractional crystallization and the interaction with magmatic fluids. The low Th/U values $(<2)$ measured on the Guérande leucogranite likely favored the crystallization of magmatic uranium oxides. The oxygen isotope compositions of the Guérande leucogranite $\left(\delta^{18} O_{\text {whole rock }}=9.7-11.6 \%\right.$ for deformed samples and $\delta^{18} \mathrm{O}_{\text {whole rock }}=12.2-$ $13.6 \%$ for other samples) indicate that the deformed facies of the apical zone underwent subsolidus alteration at depth with oxidizing meteoric fluids. Fluid inclusion analyses on a quartz comb from a uranium oxide-quartz vein of the Pen Ar Ran deposit show evidence of low-salinity fluids (1-6 wt.\% $\mathrm{NaCl}$ eq.), in good agreement with the contribution of meteoric fluids. Fluid trapping temperatures in the range of $250-350^{\circ} \mathrm{C}$ suggest an elevated geothermal gradient, probably related to regional extension and the occurrence of magmatic activity in the environment close to the deposit at the time of its formation. U-Pb dating on uranium oxides from the Pen $\operatorname{Ar}$ Ran and Métairie-Neuve deposits reveal three different mineralizing events. The first event at $296.6 \pm 2.6 \mathrm{Ma}$ (Pen Ar Ran) is sub-synchronous with hydrothermal circulations and the emplacement of late leucogranitic dykes in the Guérande leucogranite. The two last mineralizing events occur at $286.6 \pm$ 1.0 Ma (Métairie-Neuve) and 274.6 $\pm 0.9 \mathrm{Ma}$ (Pen Ar Ran), respectively. Backscattered uranium oxide imaging combined with major elements and REE geochemistry suggest similar conditions of mineralization during the two Pen Ar Ran mineralizing events at ca. $300 \mathrm{Ma}$ and ca. $275 \mathrm{Ma}$, arguing for different hydrothermal circulation phases in the granite and deposits. Apatite fission track dating reveals that the Guérande granite was still at depth and above $120^{\circ} \mathrm{C}$ when these mineralizing events occurred, in agreement with the results obtained on fluid inclusions at Pen Ar Ran.

Based on this comprehensive data set, we propose that the Guérande leucogranite is the main source for uranium in the Pen Ar Ran and Métairie-Neuve deposits. Sub-solidus alteration via surface-derived low-salinity oxidizing fluids likely promoted uranium leaching from magmatic uranium oxides within the leucogranite. The leached out uranium may then have been precipitated 
in the reducing environment represented by the surrounding black shales or graphitic quartzites. As similar mineralizing events occurred subsequently until ca. $275 \mathrm{Ma}$, meteoric oxidizing fluids likely percolated during the time when the Guérande leucogranite was still at depth. The age of the $U$ mineralizing events in the Guérande region (300 - $275 \mathrm{Ma}$ ) are consistent with those obtained on other $U$ deposits in the EHB and could suggest a similar mineralization condition, with long-term upper to middle crustal infiltration of meteoric fluids likely to have mobilized $U$ from fertile peraluminous leucogranites during the Late Carboniferous to Permian crustal extension events.

\section{Introduction:}

Uranium (U) deposits resulting solely from magmatic processes such as partial melting or fractional crystallization are rare (IAEA, 2012). In most cases, $U$ is initially mobilized from igneous rocks by hydrothermal and/or surficial fluids (e.g., Cuney, 2014). However, the $U$ fertility of igneous rocks not only depends on their total $U$ content but also on the capacity of the igneous U-bearing phases they host to be dissolved by the fluids. In peralkaline or high $\mathrm{K}$ calc-alkaline granites, most of the uranium is hosted in refractory minerals such as zircon, monazite and/or uranothorite, and, therefore, not easily leachable by fluids. In contrast, in peraluminous leucogranites, uranium is mainly hosted as uranium oxides and, as such, represent an ideal source for the formation of $U$ deposits (e.g., Cuney, 2014) as uranium oxide is an extremely unstable mineral and consequently easily leachable during oxidizing fluid circulations.

In the European Hercynian belt (EHB), a large proportion of the uraniferous deposits is spatially associated with Late-Carboniferous peraluminous leucogranites or, less frequently, monzogranites. The vein-type, episyenite-type, breccia-hosted or shear zone-hosted $U$ deposits related to these granites can be either intra- or peri-granitic. This spatial relationship can be observed in the Iberian Massif (e.g. Pérez del Villar and Moro, 1991), in the French part of the EHB (Armorican Massif and Massif Central; Cathelineau et al., 1990; Cuney et al., 1990), in the Black Forest (e.g. Hofmann and Eikenberg, 1991) and in the Bohemian Massif (e.g. Dill, 1983; Barsukov et al., 2006; Velichkin and Vlasov, 2011; Dolníček et al., 2013). In the Bohemian Massif, Black Forest, Massif Central and 
Armorican Massif, most of the $U$ mineralization was emplaced between 300 and $260 \mathrm{Ma}$ (e.g. Wendt et al., 1979; Carl et al., 1983; Eikenberg, 1988; Cathelineau et al., 1990; Hofmann and Eikenberg, 1991; Kříbek et al., 2009; Velichkin and Vlasov, 2011 and references therein). Regarding the genesis of these deposits, Turpin et al. (1990) proposed that in the Massif Central, the $U$ deposition resulted from the mixing of two types of fluids: an oxidizing surface-derived aqueous fluid able to leach $U$ from uranium oxides in the leucogranites and a reduced fluid with an inferred sedimentary origin. Similarly, meteoric and basin derived fluids were involved during the genesis of the shear zonehosted U mineralization of Okrouhlá Radouň and Rožná in the Bohemian Massif (Kř́bek et al., 2009; Dolníček et al., 2013) and their mixing likely promoted the precipitation of the $U$ leached out from the basement. For the Schlema and Schneebergs vein-type deposits (Bohemian Massif), Barsukov et al. (2006) showed that the $U$ ore originated from the leaching of the cupola of the Aue syeno-monzogranite during the interaction with oxidizing hydrothermal fluids and that the reducing nature of the metasedimentary host rocks promoted the precipitation of $\mathrm{U}$. In the western edge of the Bohemian Massif, the age of vein type deposits at ca. $295 \mathrm{Ma}$ (Carl et al., 1983; Dill, 2015 and reference therein) is synchronous with the emplacement of intragranitic uranium oxides bearing pegmatites in the Hagendorf-Pleystein province from 302.8 \pm 1.9 Ma to $299.6 \pm 1.9 \mathrm{Ma}$ (Dill et al., 2015). On the other hand, for the U vein-type deposits spatially associated with the Falkenberg monzogranite, Dill (1983) suggested that monzogranite was the major heat source for the $\mathrm{U}$ deposition but that the $\mathrm{U}$ mostly originated from the proterozoic black shales and phosphorites hosting the mineralization. For the Krunkelbach intragranitic uranium deposit in the Black Forest, the vein type mineralization mainly formed at $297 \pm 7 \mathrm{Ma}$ (Hofmann and Eikenberg, 1991). However, this deposit displays a complex history as a first uranium mineralizing event is dated at $310 \pm 3$ Ma (Wendt et al., 1979) and fluid circulations episodes likely occurred in the deposit during the Mesozoic and Paleogene times (Hofmann and Eikenberg, 1991). These authors suggest that uranium probably derived from the leaching of magmatic uranium oxides present in the host leucogranite by near surface oxidizing ground waters. The uranium was then precipitated either because of mixing with hot reducing fluids 
of sedimentary or metamorphic origin or because of a reaction with a previously deposited reduced ore assemblage. In the Iberian Massif, a Permian age has been proposed for the Saguazal brecciahosted intragranitic U deposit (Pérez del Villar and Moro, 1991), and these authors suggested that the $U$ was leached out from the host leucogranite. In contrast, for the Fé breccia-hosted deposit, it has been argued that $U$ was mobilized from the Upper-Proterozoic host metasediments in response to hydrothermal circulations involving meteoric fluids during the Eocene due to Alpine tectonics (Both et al., 1994). Therefore, in the EHB alone, numerous metallogenic models have been proposed for the genesis of $U$ mineralization. For some deposits however, several questions remain unanswered regarding the source(s) of the $U$ but also the timing of the mineralization, the nature of the fluid(s) involved and the conditions for the $U$ precipitation.

This is the case in the French Armorican Massif (western part of the EHB), where most of the uranium deposits are associated with the peraluminous leucogranites from Mortagne, Pontivy and Guérande (Fig. 1). The Guérande leucogranite was emplaced in an extensional deformation zone at ca. 310 Ma (Gapais et al., 1993, 2015; Ballouard et al., 2015). This leucogranite is associated with several U deposits and occurrences, the most important one being the Pen Ar Ran deposit (Figs. 2 and 3), a perigranitic vein-type deposit structurally located above the apical zone of the Guérande intrusion (Ballouard et al., 2015). In the Pen Ar Ran deposit, the U mineralization is found at the contact between Ordovician felsic metavolcanics and black shales (Cathelineau, 1981). Other U occurrences and deposits are known in the area, in particular in Métairie-Neuve, where uranium oxide-bearing quartz veins crosscut both the Guérande leucogranite and the metasedimentary rocks. One of the questions still debated is the origin of the $U$ found in the Pen Ar Ran deposit and other minor occurrences. Bonhoure et al. (2007) proposed that the metavolcanic country rocks were the source for the $\mathrm{U}$, based on the peculiar REE concentrations measured in the $\mathrm{UO}_{2}$ oxides. However, another possibility is that at least some of the $U$ was leached out from the Guérande leucogranite itself, which potentially represents a major source of available uranium because of the known existence of magmatic uranium oxides (Ouddou, 1984). 
This contribution follows the study of Ballouard et al. (2015) in which the tectonic, magmatic and hydrothermal framework for the Guérande leucogranite was presented. Here we provide a comprehensive set of radiometric data, oxygen isotope and fluid inclusion analyses, together with apatite fission track thermochronology, mineralogical, geochemical and geochronological data in an attempt to answer the following questions:

(1) What was the main source of $U$ (i.e. the metamorphic country rocks or the Guérande leucogranite) for the Pen Ar Ran and associated uranium deposits?

(2) What were the processes (magmatic or hydrothermal) responsible for the $U$ pre-enrichment of this source?

(3) What was the nature of the fluid(s) involved in the uranium mobilization, the geological conditions that prevailed during this mobilization (i.e. thermal and tectonic) and the uranium precipitation condition (i.e. lithological or fluid-controlled)?

(4) What was the precise timing for these events and how do they fit with the geodynamical framework of this part of the EHB?

\section{Geological framework}

The aim of this section is to present the state-of-the-art geology of the South Armorican Massif in general, and the Guérande leucogranite vicinity in particular, which is relevant for the understanding and study of the Pen Ar Ran and associated uranium deposits.

\subsection{The South Armorican Massif}

The southern part of the Armorican Massif belongs to the internal zone of the Hercynian belt in Western Europe and results from the collision of the Gondwana supercontinent with the Armorica microplate (Ballèvre et al., 2009). The South Armorican Massif is bounded to the north by the South Armorican Shear Zone (SASZ) (Fig. 1), a lithospheric-scale dextral strike-slip fault zone (Gumiaux et al., 2004) divided into two branches. North of the SASZ, the terranes belong to the Armorica microplate whereas two major suture zones have been identified in the South Armorican Domain. The first one, marked by the eclogites of Les Essarts and Audierne, separates terranes with a 
Gondwanian affinity to the south (lower allochton and parautochton) from the terranes belonging to the Moldanubian zone to the north (upper allochton). The second suture zone, materialized by the Nort-sur-Erdre fault, the Champtoceaux eclogites and the southern branch of the SASZ, separates the upper allochton terranes from the Lanvaux - Saint Georges sur Loire unit, which is interpreted as a Devonian back arc basin (Ballèvre et al., 2009) (Fig. 1). From the bottom to the top, three main groups of tectono-metamorphic units can be distinguished in the South Armorican Domain (e.g. Gapais et al., 1993, 2015) (Fig. 1):

(1) Lower units constituted of migmatites, gneisses and granitoids related to high grade metamorphism reaching P-T conditions of $0.8 \mathrm{GPa}$ and $700-750^{\circ} \mathrm{C}$ (Jones and Brown, 1990)

(2) Intermediate units mostly composed of micaschists affected by a Barrovian metamorphism from greenschist to amphibolite facies conditions (Bossière, 1988; Triboulet and Audren, 1988)

(3) Upper units related to the HP-LT metamorphism represented at the base of the pile by the Vendée porphyroid Formation, made of Ordovician felsic metavolcanics (Ballèvre et al., 2012) and black shales, and, at the top of the pile, by the blueschist klippes of Groix Island and Bois-de-Cené. The porphyroid and blueschist formations reached peak P-T conditions of $0.8 \mathrm{GPa}, 350-400^{\circ} \mathrm{C}$ (Le Hébel et al., 2002) and $1.4-1.8 \mathrm{GPa}, 500-550^{\circ} \mathrm{C}$ (Bosse et al., 2002), respectively. The subduction and exhumation of these units are related to early tectonic events that occurred between 370 and 350 Ma (Le Hébel, 2002; Bosse et al., 2005).

The Barrovian metamorphism affecting the lower and intermediate units occurred during the continental collision and was followed by a major episode of extension which induced the exhumation of migmatite domes between 310 and 300 Ma (Gapais, et al., 1993, 2015; Burg et al., 1994; Brown and Dallmeyer, 1996; Cagnard et al., 2004). During this episode of crustal thinning, several sheets of syntectonic leucogranites such as Quiberon, Sarzeau and Guérande (Fig. 1) were 
emplaced in the micaschists and below the porphyroid unit, which represented the upper brittle crust during the Upper Carboniferous (Gapais et al., 1993, 2015; Turrillot et al., 2009; Ballouard et al., 2015).

Numerous syntectonic leucogranites were also emplaced along the SASZ (Berthé et al., 1979) (Fig. 1). Among them, the Lizio and Questembert granites, which were dated at $316 \pm 6 \mathrm{Ma}$ (Tartèse et al., 2011a) and $316 \pm 3 \mathrm{Ma}$ (Tartèse et al., 2011b), respectively, formed through the partial melting of metasediments (Tartèse and Boulvais, 2010). Some giant quartz veins are also associated with the SASZ. Isotopic and fluid inclusion studies revealed that the quartz originated from both meteoric and lower crustal fluid circulations (Lemarchand et al., 2012). These veins are evidence of a crustal-scale fluid circulation that occurred between 315 and 300 Ma during a strike slip deformation along the SASZ (Tartèse et al., 2012).

Within this part of the Armorican Massif, several metal deposits, mainly Sn and U mineralization (Chauris, 1977), are spatially associated with the peraluminous leucogranites. Uranium represents the most important resource in the region and has been mined within the three uraniferous districts of Pontivy, Mortagne and Guérande up until the end of the 90's (Cathelineau et al., 1990; Cuney et al., 1990) (Fig. 1). These three districts provided around $20 \%$ of the uranium extracted in France (IRSN, 2004).

2.2. The Guérande leucogranite

\subsubsection{General framework}

The Guérande leucogranite (Fig. 2) is a 1 km thick blade-shaped structure dipping slightly northward (Bouchez et al., 1981; Vigneresse, 1983, 1995). The granite was emplaced ca. $310 \mathrm{Ma}$ ago (U-Pb on zircon and monazite, Ballouard et al., 2015) in an extensional deformation zone (Gapais et al., 1993, 2015; Ballouard et al., 2015). To the north, the granite intrudes micaschists that were affected by contact metamorphism as indicated by the occurrence of staurolite and garnet (Valois, 1975). In contrast, to the south, the Guérande leucogranite presents a progressive contact with migmatites. Several micaschist bodies, hectometers to kilometers in size, are found within the 
leucogranite. The southwestern edge of the intrusion is crosscut by a kilometer-size isotropic leucogranitic intrusion which does not present any evidence of deformation (leucogranite isotropic sub-facies intrusion; Fig. 2).

In the Guérande leucogranite, the foliation dips generally $20-30^{\circ}$ to the north with a dip-slip type lineation. A zone of intense strain is localized in the northern zone of the granite and is characterized by $\mathrm{S} / \mathrm{C}$ and mylonitic fabrics. The northwestern part of the intrusion is also affected by an extensional graben, the so-called "Piriac graben" where metavolcanics and black shales from the Vendée porphyroid formation crop out (Fig. 3). Some authors interpreted this structure as the result of the collapse of the roof of the intrusion (Valois, 1975; Cathelineau 1981; Cottaz et al., 1989). The Ordovician metavolcanics of the Piriac graben were affected by the emplacement of the Guérande leucogranite as demonstrated by muscovite ${ }^{40} \mathrm{Ar} /{ }^{39} \mathrm{Ar}$ dates at $311.8 \pm 0.5 \mathrm{Ma}$ and $313.4 \pm 0.4 \mathrm{Ma}$ (Le Hébel, 2002).

2.2.2. Tectonic evolution and magmatic-hydrothermal history of the Guérande leucogranite.

The aim of this section is to summarize the recent structural, petro-geochemical and geochronological study performed on the Guérande leucogranite by Ballouard et al. (2015). The Guérande leucogranite displays structural heterogeneities at the scale of the intrusion with a weak deformation in the southwestern part, whereas the northern part is marked by the occurrence of S/C and mylonitic extensional fabrics. Quartz veins and pegmatite dykes orientations, as well as stretching lineation directions in the granite and its country rocks, both show E-W and N-S stretching directions. Therefore, during its emplacement in an extensional regime, the leucogranite experienced some partitioning of the deformation and the main top to the north stretching direction recorded in the area is locally accommodated by E-W motions.

The southwestern part of the intrusion is characterized by a muscovite-biotite assemblage, the presence of restite and migmatite enclaves and a low abundance of quartz veins compared to pegmatitic dykes. In contrast, the northwestern part is characterized by a muscovite-tourmaline 
assemblage, evidence for both albitization and greisenization (Fig. 2) and a higher number of quartz veins. These observations, together with the northward dipping foliation, are consistent with the fact that the southwestern part corresponds to the feeding zone of the intrusion while the northwestern part corresponds to its apical zone.

The samples studied by Ballouard et al. (2015) have variable grain-size, from aplitic (0.5 - 1 $\mathrm{mm}$, in dykes) to coarse-grained ( $3-5 \mathrm{~mm})$. All the samples contain a quartz-feldspar-muscovite assemblage with variable amounts of biotite and tourmaline. Biotite hosts most of the accessory minerals such as apatite, Fe-Ti oxide, zircon and monazite. No magmatic uranium oxide was observed during this study. However, such oxides have been reported by Ouddou (1984) and Friedrich et al. (1987) in a drilled core of a highly evolved coarse-grained facies from this leucogranite. This sample, which has a $U$ content of $20 \mathrm{ppm}$, was recovered at a depth of $160 \mathrm{~m}$ in the northwestern part of the leucogranite at the contact with the micaschists.

In terms of alteration, indices of chloritization are localized in the northern central part of the intrusion whereas muscovitization, greisenization and albitization are restricted to the apical zone to the northwest (Fig. 2). In this area, albitization, associated with dequartzification, largely affected the chemical composition of some of the samples.

High initial ${ }^{87} \mathrm{Sr} /{ }^{86} \mathrm{Sr}$ ratios (0.7149 to 0.7197$)$ and low $\varepsilon N d(T)(-9.0$ to -7.8$)$ values suggest that the Guérande leucogranite $(A / C N K>1.1)$ was formed by partial melting of Upper-Proterozoic to Paleozoic metasediments. Fractional crystallization affected the granitic melts, reaching $15-30 \%$ fractionation of K-feldspar, plagioclase, biotite and accessory minerals (apatite, zircon and monazite) in the most evolved samples. The apical zone is characterized by high contents of highly incompatible elements, such as Sn or Cs, which cannot be solely explained by a fractional crystallization process. Rather these distributions are consistent with a pervasive hydrothermal alteration that took place during (or soon after) crystallization of the magma. Zircon and monazite U-Th-Pb dating indicate that the Guérande leucogranite was emplaced ca. $310 \mathrm{Ma}$ ago and that a second magmatic event, represented by the emplacement of leucogranite dykes, occurred at ca. $303 \mathrm{Ma}$. This age of ca. 303 
$\mathrm{Ma}$ is directly comparable with the muscovite ${ }^{40} \mathrm{Ar} /{ }^{39} \mathrm{Ar}$ dates of $303.3 \pm 0.5 \mathrm{Ma}$ obtained for a quartz vein and of $303.6 \pm 0.5 \mathrm{Ma}$ and $304 \pm 0.5 \mathrm{Ma}$ obtained for a sheared granite and on a mylonitic $\mathrm{S} / \mathrm{C}$ granite sampled in the apical zone of the intrusion, respectively (Le Hébel, 2002). This information suggests that deformation and hydrothermal circulations were both active at ca. $303 \mathrm{Ma}$ and were contemporaneous with a late magmatic event.

\subsubsection{The $U$ mineralization}

The Guérande leucogranite and its surrounding host rocks are spatially associated with Sn and $U$ mineralization (Fig. 2). The Sn mineralization, represented by cassiterite-bearing quartz veins, is located in the northwestern part of the leucogranite (Audren et al., 1975) (Figs. 2 and 3), whereas $\mathrm{U}$ deposits are found exclusively in the central and northern parts of the intrusion. They are either perigranitic, hosted in the metamorphic country rocks (Pen Ar Ran), or intragranitic, hosted within the leucogranite itself or within pluridecametric metamorphic enclaves (Keroland, Métairie-Neuve ; Cathelineau, 1981) (Fig. 2).

The most important deposit is the Pen Ar Ran deposit where around 600 tons of uranium have been extracted (IRSN report, 2004). In this deposit, uranium oxide veins crosscut the metavolcanics (Fig. 4a) and are localized at the contact with black shales in a sub-vertical sinistral $\mathrm{N}$ $110^{\circ}$ shear zone within the "Piriac graben" (Cathelineau, 1981) (Fig. 3). The mineralization fills brittle structures oriented $\mathrm{N} 90^{\circ}$ and $\mathrm{N} 70^{\circ}$ that crosscut the foliation of the metavolcanics but are blocked at the contact with reducing black shales (Fig. 4b). These mineralized fractures correspond to Riedel or to tension gashes associated with sinistral $\mathrm{N} 110^{\circ}$ faults (Cathelineau, 1981) (Fig. 4c). Cathelineau (1981) described a quartz-pitchblende mineralization event which represents more than $90 \%$ of the vein infilling. This event began with the development of a millimeter-size quartz comb where spherulitic pitchblende crystallized first, followed by prismatic pitchblende. The axial zone of the veins is locally filled with sulfides (mostly pyrite, marcasite, and chalcopyrite) commonly fracturing the previous pitchblende filling. Finally, a late reworking of the uranium oxides induced the 
precipitation of secondary hexavalent U-bearing minerals such as phosphates, oxides or vanadates (Fig. 4b and c).

In the Métairie-Neuve deposit (Fig. 2) (production of around 10 tons of $\mathrm{UO}_{2}$ ), the uranium mineralization was formed in a hectometer-size enclave made up of micaschists and graphitic quartzites. The mineralization is expressed as centimeter-thick quartz-uranium veins, similar to the Pen Ar Ran deposit, but with a smaller size and volume. The uranium oxide veins crosscut both the metasediments and leucogranite (Cathelineau, 1981).

A pioneer fluid inclusion study (Cathelineau, 1982) on a quartz comb associated with an uranium oxide vein from the Pen Ar Ran deposit has shown that a low salinity (3-5 wt.\% $\mathrm{NaCl}$ eq.) mineralizing fluid was trapped at a temperature between 340 and $380^{\circ} \mathrm{C}$ and a low pressure; this temperature is anomalously high when compared to other $U$ deposits in the EHB $\left(150-250^{\circ} \mathrm{C}\right.$, Cathelineau et al., 1990).

The REE concentrations measured in the uranium oxides from the Pen Ar Ran deposit are typically low but the patterns show a significant fractionation from LREE to HREE with an enrichment in Sm, Eu and Gd (Bonhoure et al., 2007). Based on the comparison with some clearly volcanicrelated $U$ deposits, these spectra have been interpreted as an indicator that the probable $U$ source for the Pen Ar Ran deposit was the enclosing metavolcanic rocks (Bonhoure et al., 2007).

\section{Analytical techniques}

3.1. Oxygen isotope analyses

Oxygen isotope analyses were performed in the stable isotope laboratory at the University of Lausanne, Switzerland. The oxygen isotope composition of whole-rock samples and minerals (quartz and feldspar) from the Guérande granite, reported in the standard $\delta^{18} \mathrm{O}$ notation, were measured using a $\mathrm{CO}_{2}$-laser fluorination line coupled to a Finnigan MAT 253 mass spectrometer. The detailed methodology is provided as supplementary material. For each run, the results, reported in per mill (\%o) relative to VSMOW (Vienna Standard Mean Ocean Water), were normalized using the analyses carried out on the quartz standard LS1 (reference value: $\delta^{18} \mathrm{O}=18.1 \%$ vs. VSMOW). The precision, 
based on replicate analyses of the standard run together with the samples, was generally better than $0.2 \%$.

\subsection{Radiometric data}

A detailed airbone radiometric survey was performed over the Armorican Massif by the BRGM (Bureau de Recherche Géologique et Minière). The detailed acquisition and treatment methods applied to the airborne radiometric data are provided in Bonijoly et al. (1999). To get complementary radiometric data at a smaller scale, qualitative measurement of the $\mathrm{U}$, Th and $\mathrm{K}$ contents were carried out on selected outcrops using a portable spectral gamma ray (RS-230 BGO Super-Spec - Radiation Solution, this study). The duration of analysis was 3 minutes and the results reported in Table 1 correspond to the average of three analyses performed on an outcrop surface of about $4 \mathrm{~m}^{2}$. No analytical biases were noticed whether the measurements were done perpendicularly or parallel to the foliation planes.

\subsection{Apatite fission tracks analysis}

Apatite fission track (AFT) analysis was performed on three samples from the Guérande leucogranite using the external detector method (see supplementary material for details on the method). The AFT measurements were made in Géosciences Rennes using a Zeiss Axioplan 2 microscope with a $1250 x$ magnification under dry lenses. For each samples, a total of 20 inclusionfree apatite grains oriented parallel to the c-axis were measured using the TrackWorks software (on manual mode) developed by the Autoscan company (Australia). Age calculations were done using the TrackKey software (Dunkl, 2002). A weighted mean zeta value of $335.9 \pm 6.8 \mathrm{yr} \mathrm{cm}^{2}$ (CB) obtained on both the Durango (McDowell et al., 2005) and Mount Dromedary (Green, 1985; Tagami, 1987) apatite standards was used. All ages reported in this study are central ages (Galbraith and Laslett, 1993) reported at $\pm 2 \sigma$. Measurements of the horizontal track lengths and their respective angle with c axis, as well as the mean $D_{\text {par }}$ value (e.g. Jolivet et al., 2010; Sobel and Seward, 2010) were obtained for each sample. The $D_{\text {par }}$ value corresponds to the etched trace of the intersection of a fission track with the surface of the analyzed apatite (parallel to the $c$ axis). The mean $D_{\text {par }}$ value used for each 
sample was obtained by measuring more than $300 \mathrm{D}_{\text {par }}$. Inverse time-temperature history modeling was performed using the QTQt software (Gallagher et al., 2009; Gallagher, 2012) with the annealing model of Ketcham et al. (2007) that takes into account the $D_{\text {par }}$ parameter to constrain the annealing kinetic of fission tracks. The time-temperature history modeling is only well constrained in the temperature interval $60-120^{\circ} \mathrm{C}$ which corresponds to the partial annealing zone (PAZ) of apatite fission tracks.

\subsection{Fluid inclusion analyses}

The petrography, microthermometry and Raman analyses of the fluid inclusions were carried out at the GeoRessources laboratory (Nancy, France) on a thick section of a quartz comb associated with an uranium oxide vein from the Pen Ar Ran deposit. Microthermometric measurements were performed on a Linkam THMS600 heating-cooling stage connected to an Olympus BX51 microscope. The fluid inclusions used for the calibration were a $\mathrm{CO}_{2}$ standard fluid inclusion (triple point at $56.9^{\circ} \mathrm{C}$ ) and two $\mathrm{H}_{2} \mathrm{O}$ standards fluid inclusions with an ice melting and a homogenization temperature of $0.0^{\circ} \mathrm{C}$ and $165^{\circ} \mathrm{C}$, respectively. Raman microspectrometry analyses were performed on both the vapor and liquid phases of the fluid inclusions using a LabRAM HR Raman spectrometer (Horiba Jobin Yvon) equipped with an 1800 gr.mm $\mathrm{mm}^{-1}$ grating and an Edge filter. The confocal hole aperture was $500 \mu \mathrm{m}$ and the slit aperture $100 \mu \mathrm{m}$. The excitation beam was provided by a Stabilite $2017 \mathrm{Ar}^{+}$laser (Spectra Physics, Newport Corporation) at $514 \mathrm{~nm}$ and a power of $200 \mathrm{~mW}$, focused on the sample using a 100x optical zoom lens (Olympus). The acquisition time and the number of accumulations were chosen in order to optimize the signal-to-noise ratio $(\mathrm{S} / \mathrm{N})$. Salinity is expressed as weight equivalent percent $\mathrm{NaCl}$ (wt.\% $\mathrm{NaCl}$ eq.) and has been calculated using the measured ice melting temperature (Tm Ice) with the equation of Bodnar (1993) and Raman analyses (Caumon et al., 2013, 2015).

\section{5. $\quad U$ oxide analyses and dating}

Petrography, imaging, as well as major and trace element analyses of selected polished thin sections and mounts of uranium oxide samples from the Pen Ar Ran and Métairie-Neuve deposits 
were carried out at the GeoRessources laboratory (Nancy, France). U-Pb dating was carried out at the Centre de Recherches Pétrographiques et Géochimiques (CRPG, Nancy, France) by secondary ion mass spectrometry (SIMS). The $U$ oxide samples were first examined using reflected light microscopy. We then selected appropriate areas suitable for laser ablation-inductively coupled plasma mass spectrometry (LA-ICP-MS) and SIMS analyses (areas without evidence of post-crystallization alterations and having high radiogenic lead contents) based on back-scattered electron (BSE) images obtained using both a JEOL J7600F and a HITACHI S-4800 scanning electron microscopes and major element analyses obtained using a CAMECA SX100 electron microprobe (EPMA). The rare earth element ( $\mathrm{La}, \mathrm{Ce}, \mathrm{Pr}, \mathrm{Nd}, \mathrm{Sm}, \mathrm{Eu}, \mathrm{Gd}, \mathrm{Tb}$, Dy, Ho, Er, Tm, Yb, Lu) concentrations in the uranium oxides were quantified using a LA-ICP-MS system composed of a GeoLas excimer laser (ArF, $193 \mathrm{~nm}$, Microlas) coupled to an Agilent 7500c quadrupole ICP-MS. The detailed methodology is provided as supplementary material and followed the one proposed by Lach et al. (2013). U-Pb isotope analyses were performed using a CAMECA IMS 1270 ion microprobe. The complete methodology is described in Mercadier et al. (2010). Ages, calculated using the ISOPLOT software (Ludwig, 2012), are provided with their $2 \sigma$ uncertainties. All the isotopic ratios are provided in supplementary Table 1.

\section{Results}

In this section we successively present the petrographic and geochemical characteristics of the deposits (uranium oxides and fluid inclusion analyses) and the country rocks (Guérande leucogranite, black shales and metavolcanics).

4.1. Uranium deposits

\subsubsection{Uranium oxide petrography}

Three uranium oxide samples from the Pen Ar Ran deposit and two from the Métairie-Neuve deposit were analyzed in detail. The selection of these samples, representative of the different types and habitus of the uranium oxides and host rocks described for the two deposits, was based on the initial work on the deposits carried out by Cathelineau (1981; 1982). 
The three uranium oxide samples from the Pen Ar Ran deposit have specific morphologies: (1) a spherulitic facies ("PAR-spherulitic"; Fig. 5a), (2) a pseudo-spherulitic facies ("PAR-pseudospherulitic"; Fig. 5b and 5c) and (3) a prismatic facies ("PAR-prismatic"; Fig. 5d). In the spherulitic facies, the spherules, which have grown on a millimeter-size quartz comb, have a diameter of $500 \mu \mathrm{m}$ to $2 \mathrm{~mm}$ and display micrometer-size concentric zoning, likely reflecting overgrowth of uraninite zones around a more homogeneous uraninite core (Fig. 5a). On the BSE images, the rims of the spherules commonly display a dark-grey color (lowest mean atomic mass Z) whereas the cores display a light-grey color (higher Z; Fig. 5a). The spherules (Ur1) are locally brecciated by sulfides (mostly pyrite, chalcopyrite, marcasite). Some micrometric fractures crosscut the spherules and induced the alteration of the first generation of uranium oxides (alt Ur1). The pseudo-spherulitic facies is characterized by millimeter- to centimeter-size partially developed spherules which have grown on $\sim 500 \mu \mathrm{m}$ thick quartz comb (Qtz, Fig. 5b). Sulfide minerals fill the central parts of the vein and locally crosscut Ur1 as micrometer-size veinlets (Py and CPy, Fig. 5b) that are related to the alteration of Ur1 (Alt Ur1). Ur1 is also characterized by chemically homogenous areas within the uranium oxide which were chosen for U-Pb dating (Fig. 5c; see the geochronological section below). In the prismatic facies, the BSE imaging also revealed large-scale homogenous areas within the uranium oxide (Fig. $5 \mathrm{~d}$ ).

For the Métairie-Neuve deposit, one sample comes from a vein crosscutting the Guérande leucogranite ("MN-granitic C.R."; Fig. 5e) and the second sample from a vein crosscutting metasedimentary rock enclaves in the leucogranite ("MN-metased. C.R."; Fig. 5f). Both uranium oxides display a prismatic morphology. In the "MN-granitic C.R." sample, the uranium oxide (Ur1) is crosscut by micro-fractures associated with the alteration of Ur1 (Alt Ur1) and the crystallization of micrometer-size crystals of galena (Gn, Fig. 5e). Some fractures can be filled with a late fibrous uranium phosphate mineral (U-Ca-K-PO ; Fig. 5e). In the "MN-metased. C.R." sample, the uranium oxide displays a homogenous composition on the BSE image (Fig. 5f). 
The precise and small-scale observations of the different uranium oxides Ur1 from the Pen Ar Ran and Métairie-Neuve deposits clearly indicate that they present limited alteration patterns, and that consequently the measured isotopic ratios and trace element contents in these minerals can be considered as reflecting the crystallization processes rather than later alteration events.

\subsubsection{Uranium oxide geochemistry}

The average major and REE element compositions of the uranium oxides analyzed in this study are reported in Table 2. For the "PAR-spherulitic" sample, the analyses performed on the core of the spherules were distinguished from the analyses made on the rim. We also separated the analyses carried out on the altered uranium oxides (Alt Ur1).

For the Pen Ar Ran deposit, the average $\mathrm{UO}_{2}$ contents of the uranium oxides Ur1 range from 80.2 to 82.8 wt.\% (Table 2 ) whereas the Th content is below the detection limit $(<0.1 \mathrm{wt} . \%$ ). These uranium oxides are characterized by an elevated but variable content in $\mathrm{PbO}$ which ranges from 3 wt.\% to 9 wt.\%, the maximum PbO content being recorded in the core of the spherules of the "PARspherulitic" sample (Fig. 6a). The CaO content is also highly variable, ranging from $4 \mathrm{wt. \%}$, in the core of the spherules of the "PAR-spherulitic" sample, to more than 10 wt.\% in the "PAR-pseudospherulitic" sample; the other uranium oxides present intermediate contents (Fig. 6a). The PbO content in the "PAR-spherulitic" sample is anti-correlated with the $\mathrm{CaO}$ contents (Fig. 6a). In the uranium oxides $\mathrm{Ur} 1$, the average content in $\mathrm{SiO}_{2}$ ranges from 1.0 to 1.4 wt.\% while $\mathrm{FeO}$ is generally below the detection limit. The analyses performed on the altered uranium oxides (Alt Ur1) from the "PAR-spherulitic" sample revealed lower $\mathrm{UO}_{2}, \mathrm{CaO}$ and $\mathrm{PbO}$ contents and an increase in the $\mathrm{P}_{2} \mathrm{O}_{5}$ and FeO contents (Table 2). In the Métairie-Neuve deposit, both uranium oxides display overall similar major element compositions (average $\mathrm{UO}_{2}$ content of 84.4 and 84.9 wt.\% in the "MN-granitic C.R." and "MN-metased. C.R." samples, respectively), comparable with the composition of the uranium oxides Ur1 from the Pen Ar Ran deposit (Table 2). However, the PbO content is less variable in the “MN-granitic. C.R." sample (3.5-3.8 wt.\%) than in the "MN-metased. C.R." sample (2.7 - 8.6 wt.\%). 
The REE spectra of the uranium oxides from the Pen Ar Ran and Métairie-Neuve deposits display variable patterns, but are all characterized by relatively low REE contents (Fig. 6b-c-d). In the spherulitic facies from Pen Ar Ran (Fig. 6b), the REE spectra display a progressive evolution from the core to the rim of the spherules with a decrease in the total REE content (mean $\Sigma$ REE from 145 to 24 ppm; Table 2) mainly based on a decrease in the MREE and HREE contents, introducing an increase in the fractionation of LREE (mean $\mathrm{La}_{N} / \mathrm{Sm}_{N}$ from 33 to 782 ). Some of the spectra (e.g. 5a, 5b, 6a; Fig. 6b) display a saddle-shape from La to Gd whereas some patterns from the cores ( $1 a, 1 b, 3 a, 3 b$ and 6b) are marked by a negative Eu anomaly (average Eu/Eu* $=0.4$ ). The pseudo-spherulitic and prismatic facies of Pen Ar Ran display homogenous REE spectra (Fig. 6c) characterized by a fractionation from La to $\mathrm{Sm}$ (mean $\mathrm{La}_{N} / \mathrm{Sm}_{N}$ of 4.5 for the "PAR-pseudo-spherulitic" sample and 3.9 for the "PAR-prismatic" sample) and a negative Eu anomaly (average Eu/Eu* $=0.7$ ). The prismatic facies displays a higher total REE content than the pseudo-spherulitic facies (mean $\Sigma$ REE of 120 and 34 ppm, respectively).

The REE patterns of the two uranium oxide samples from the Métairie-Neuve deposits are similar (Fig. 6d) but differ from the majority of the spectra from the Pen Ar Ran deposit (Fig. 6b). Their REE content is very low with a mean $\Sigma$ REE of 18.3 and 3.7 ppm for the "MN-granitic C.R." and “MN-metased. C.R." samples, respectively (Table 2). Two different LREE patterns are displayed, either a linear negative slope or a saddle shape from La to $\mathrm{Sm}$ (mean $\mathrm{La}_{N} / \mathrm{Sm}_{\mathrm{N}}$ of 3.5 for the "MNgranitic C.R." sample and 5.3 for the "MN-metased. C.R." sample). All the patterns are marked by a positive Eu anomaly (average Eu/Eu* of 1.6 for "MN-granitic C.R." and 2.0 for "MN-metased. C.R.") and a fractionation from Gd to Lu.

\subsubsection{Fluid inclusions in quartz}

The fluid inclusions study was performed on a quartz comb from a uranium oxide vein from Pen Ar Ran such as shown in Fig.5b. Most of the fluid inclusions are generally found in clusters or along quartz growth zones and have been identified as primary in origin. Secondary fluid inclusions are small and rare, and have not been studied. The primary fluid inclusions (Fig. 7) have a moderate 
size $(10-30 \mu \mathrm{m})$, and can be elongated in the direction of the growth of their host quartz crystal (Fig. 7a). Several inclusions of muscovite occur in the quartz and can be locally observed inside or at the border of the fluid inclusions (Fig. 7d). The inclusions are all biphasic at room temperature with a highly variable degree of gas filling (Fig. 7) from 10 to $90 \%$. The result of the microthermometric and Raman analyses of the representative fluid inclusions are reported in Table 3. All the fluid inclusions are aqueous and the volatile phase contains a variable amount of $\mathrm{O}_{2}-\mathrm{H}_{2}-\mathrm{N}_{2}$. The salinity of the liquid phase varies significantly from 0.9 to $6.4 \mathrm{wt} . \% \mathrm{NaCl}$ eq. (Fig. 8a). The homogenization temperatures $\left(T_{h}\right)$ range from 287 to $461{ }^{\circ} \mathrm{C}$ (Fig. 8b). Lowest $T_{h}\left(<360^{\circ} \mathrm{C}\right)$ are characteristic of inclusions homogenizing in the liquid phase whereas highest $T_{h}$ were obtained for fluid inclusions which homogenize in the vapor phase (Fig. 8b). Overall, the ranges of $T_{h}$ and liquid phase salinities measured in this study are larger than those obtained by Cathelineau (1982). There is no evident correlation between $T_{h}$ and liquid salinity (Fig. 8c), although the highest salinities are mostly found within the inclusions presenting the highest $T_{h}$ and homogenizing in the vapor phase. Finally, the $T_{h}$ are correlated with the gas bubble size (Fig. 8d).

\subsubsection{U-Pb Geochronology}

The results of the SIMS U-Pb isotope analyses on the uranium oxides from the Pen Ar Ran and Métairie-Neuve deposits are reported in the supplementary Table 1. All the analyses, performed on homogenous and fresh uranium oxide areas, display highly elevated common $\mathrm{Pb}$ contents with ${ }^{204} \mathrm{~Pb} /{ }^{206} \mathrm{~Pb}$ values ranging from 0.0010 (“MN-metased. C.R." sample) to 0.020 ("PAR-spherulitic" sample). For this reason, a common $\mathrm{Pb}$ correction was applied, based on the measured ${ }^{204} \mathrm{~Pb}$ content and using Stacey and Kramers (1975) common Pb isotopic composition calculated for the estimated age of the uranium oxide crystallization.

\section{Pen Ar Ran: spherulitic facies}

Among the 18 analyses performed on the "PAR-spherulitic" sample, 16 were performed in the cores of the spherules and two in the rims (Fig. 5a). For the cores, the 16 common Pb-corrected analyses plot in a concordant to sub-concordant position in a Wetherill concordia diagram and allow 
to calculate a concordia date of $296.6 \pm 2.6 \mathrm{Ma}$ (MSWD = 1.2; Fig. 9a). In a Tera-Wasserburg diagram (Fig. 9b), these 16 analysis, uncorrected for common $\mathrm{Pb}$, plot in a discordant position. A regression line anchored to the composition of common $\mathrm{Pb}$ at $300 \mathrm{Ma}$, following Stacey and Kramers (1975) model for Pb evolution, yields a lower intercept date of 294.4 $\pm 3.4 \mathrm{Ma}$ (MSWD $=11.7$ ). This less wellconstrained date is comparable within error with the concordia date calculated above so we conclude that the cores of the spherules from this uranium oxide sample crystallized at $296.6 \pm 2.6$ Ma. The two common Pb-corrected analyses for the rim of the spherules (Fig. 5a) plot in apparent sub-concordant positions in the Wetherill concordia diagram (Fig. 9a) and yielded apparent ${ }^{206} \mathrm{~Pb} /{ }^{238} \mathrm{U}$ dates of $270.6 \pm 2.4$ and $282.7 \pm 2.8 \mathrm{Ma}$ and ${ }^{207} \mathrm{~Pb} /{ }^{235} \mathrm{U}$ dates of $278.1 \pm 4.7$ and $285.2 \pm 5.1 \mathrm{Ma}$, respectively.

\section{Pen Ar Ran: pseudo-spherulitic and prismatic facies}

A total of 23 and 29 analyses were carried-out on the "PAR-pseudo-spherulitic" and "PARprismatic" samples, respectively (Figs. $5 c$ and 5d). For the "PAR-pseudo-spherulitic" sample, all the common $\mathrm{Pb}$ corrected analyses plot in a concordant position in the Wetherill concordia diagram (Fig. 9c). For the "PAR-prismatic" sample, 28 analyses out of 29 are concordant (Fig. 9c). Together, 51 analyses from the two samples allow to calculate a well-defined concordia date of $274.6 \pm 0.9 \mathrm{Ma}$ (MSWD = 1.4). The only discordant analysis (not shown here) obtained on the prismatic facies yields apparent ${ }^{206} \mathrm{~Pb} /{ }^{238} \mathrm{U}$ and ${ }^{207} \mathrm{~Pb} /{ }^{235} \mathrm{U}$ dates of $152 \pm 2$ and $159 \pm 5 \mathrm{Ma}$, respectively, and likely underwent $\mathrm{Pb}$ loss. In a Tera Wasserburg diagram, the 51 analyses, uncorrected for common $\mathrm{Pb}$ and used for the calculation of the concordia date, plot in a discordant position (Fig. 9d). A regression line, anchored to the common Pb composition at $275 \mathrm{Ma}$ (Stacey and Kramers, 1975), yields a lower intercept date of $274.9 \pm 1.1 \mathrm{Ma}(\mathrm{MSWD}=5.7)$ that is identical within error to the concordia date of $274.6 \pm 0.9$ Ma. Consequently, we argue that these two uranium oxide types crystallized $274.6 \pm 0.9$ Ma ago.

\section{Métairie-Neuve}


A total of 12 analyses were performed on each sample from the Métairie-Neuve deposit ("MN-granitic C.R." and "MN-metased.C.R."; Fig. 5e and 5f). All together, these 24 analyses, corrected for common Pb, plot in a concordant to sub-concordant position in the Wetherill concordia diagram and allow to calculate a concordia date of $286.6 \pm 1.0 \mathrm{Ma}$ (MSWD =1.4; Fig. 9e). These 24 analyses, uncorrected for common $\mathrm{Pb}$, plot in a discordant position in the Tera Wasserburg diagram (Fig. 9f). A regression line anchored to the composition of common $\mathrm{Pb}$ at $285 \mathrm{Ma}$ (Stacey and Kramers, 1975) allows to calculate a lower intercept date of $286.5 \pm 1.2 \mathrm{Ma}(\mathrm{MSWD}=3.3$ ). These two dates are identical within error. As a consequence, we infer that these uranium oxides crystallized at $286.6 \pm 1$ Ma.

4.2. The Guérande leucogranite and surrounding country rocks

\subsection{1. $U$ and Th distribution}

The $U$ airborne radiometric map of the Guérande leucogranite and its country rocks is displayed in Figure 10a. The variations of $U$ contents allow to differentiate two main domains within the intrusion. The southern and the northeastern part of the leucogranite are characterized by high $U$ contents (brown color) whereas the northwestern part, interpreted as the apical zone of the intrusion by Ballouard et al. (2015), is characterized by low U contents (yellow to white colors). U deposits are systematically located inside or at the border of the "high U content" zones. For the country rock, the $U$ contents are variable but the metavolcanics (Vendée porphyroid unit) and migmatites (south-east) are characterized by a high $\mathrm{U}$ content (brown color).

We also performed $\mathrm{U}$, Th and $\mathrm{K}$ gamma-ray analyses on the Guérande leucogranite and its metamorphic country rocks (metavolcanics and black shales of the Piriac graben, Fig. 3) using a portable gamma-ray spectrometer. The measurements were mostly taken along the coastline from La Turballe to Piriac (Fig. 2) as there are only a few outcrops inland. The results of the analyses are reported in Table 1 and in a $U$ vs. Th diagram (Fig. 10b) together with the ICP-MS data from the leucogranite (Ballouard et al. 2015) and metavolcanics (Le Hébel 2002). In this diagram, the analyses performed on the Guérande leucogranite using the gamma-ray spectrometer are in a good 
agreement with the ICP-MS analyses made on whole-rock samples (Ballouard et al., 2015) and mostly have Th/U values below 2. For the metavolcanics (of the Vendée porphyroid unit), the Th/U values are between 2 and 5 . These values are comparable with the values obtained by the ICP-MS method on whole-rock porphyroid samples from the Piriac graben $(2<$ Th/U $<4$; Le Hébel, 2002) and on other Ordovician metavolcanic samples from the South Armorican Massif $(2<\mathrm{Th} / \mathrm{U}<15$ : porphyroids from Vendée and Belle-lle) (Le Hébel, 2002). Finally, the black shales have intermediate Th/U values between 0.5 and 3 .

\subsubsection{Oxygen isotope compositions}

The oxygen isotope compositions measured on whole-rock and mineral separates (quartz and feldspar) from the Guérande leucogranite samples are reported in Table 4 and summarized in Figure 11. The whole-rock $\delta^{18} \mathrm{O}$ values have a range from 12.2 to $12.9 \%$ in the root and transitional facies and a range from 9.7 to $13.6 \%$ in the apical zone facies. The high $\delta^{18} \mathrm{O}$ values are comparable with the values obtained on other Carboniferous leucogranites from the Armorican Massif (BernardGriffiths et al., 1985; Tartèse and Boulvais, 2010) and are consistent with the metasedimentary source proposed for the Guérande leucogranite by Ballouard et al. (2015).

In Figure 11a, the $\delta^{18} \mathrm{O}$ values of the minerals (quartz and feldspar) are reported as a function of the $\delta^{18} \mathrm{O}$ values of the whole-rock samples. Four samples (GUE-6, 7, 9 and 21) have feldspar and/or whole-rock $\delta^{18} \mathrm{O}$ values below the values of the other samples $\left(\delta^{18} \mathrm{O}_{\mathrm{WR}}<12\right.$ and $\left.\delta^{18} \mathrm{O}_{\mathrm{Fds}}<10\right)$. These low $\delta^{18} \mathrm{O}$ samples have $\Delta^{18} \mathrm{O}_{(\mathrm{Q} z-\mathrm{Fds})}$ between 4.4 and 4.7 , which would correspond to meaningless low temperatures of equilibration between 70 and $90^{\circ} \mathrm{C}$, whereas the other samples have high equilibration temperatures between 408 and $599^{\circ} \mathrm{C}$ (Table 4).

In Figure $11 \mathrm{~b}$, most of the $\delta^{18} \mathrm{O}$ values of the whole-rock and minerals correlate with the geographic latitude of the samples and the highest $\delta^{18} \mathrm{O}$ values have been measured for rocks in the apical zone facies. Whole-rock, quartz and feldspar $\delta^{18} \mathrm{O}$ values increase by about $1 \%$ from south to north of the intrusion. The four samples with the low $\delta^{18} \mathrm{O}$ values of the feldspar and/or the wholerock (GUE-6, 7, 9 and 21) are localized to the north of the intrusion and plot below the trend defined 
by the other samples whereas the quartz displays a continuous trend. These low $\delta^{18} \mathrm{O}$ samples which belong either to the apical zone facies or to the root and transitional facies, are a mylonitic $\mathrm{S} / \mathrm{C}$ granite (GUE-9), a S/C granite (GUE-6), a fine grained granite affected by solid state deformation (GUE-7) and an altered granite (GUE-21) collected near a greisen affected by dequartzification and potassic feldspar neoformation (Ballouard et al., 2015). These observations suggest a relationship between solid-state deformation and the isotopic disequilibrium between quartz and feldspar recorded by these samples.

\subsubsection{Apatite fission track (AFT) thermochronology}

The results of the AFT analysis performed on three samples from the Guérande leucogranite are reported in Table 5 and Figure 12. The GUE- 5 granite is a dyke intrusive into the GUE- 4 granite whereas the GUE-3 granite sample was collected in the northwestern edge of the intrusion (Fig. 2). No tectonic discontinuity has been identified between the two sampling areas. The crystallization ages of GUE-3, GUE-4 and GUE-5 leucogranite have previously been obtained on zircon and monazite by LA-ICPMS U-Th-Pb dating at $309 \pm 1.9 \mathrm{Ma}, 309.7 \pm 1.3 \mathrm{Ma}$ and $302.5 \pm 1.6 \mathrm{Ma}$, respectively (Ballouard et al., 2015).

The three granite samples GUE-3, GUE-4 and GUE-5 yield slightly different central AFT dates of $168 \pm 7 \mathrm{Ma}, 177 \pm 8 \mathrm{Ma}$ and $156 \pm 6 \mathrm{Ma}$, respectively (Fig. 12). The mean track lengths of the samples are similar, ranging from 13.1 to $13.3 \mu \mathrm{m}$. Yet, the GUE-5 sample displays a mean $D_{\text {par }}$ value of $1.2 \mu \mathrm{m}$, slightly lower than the values obtained for the GUE-3 and GUE-4 samples ( $\left.D_{\text {par }}=1.5 \mu \mathrm{m}\right)$. The lower $D_{\text {par }}$ value of the GUE-5 granite, which reflects a relatively faster rate of fission track annealing, could account for its younger apparent age. Data from the three leucogranite samples were used together to model the low-temperature thermal history of the Guérande leucogranite using the QTQt software (Fig. 12a) (Gallagher, 2012). The muscovite ${ }^{40} \mathrm{Ar} /{ }^{39} \mathrm{Ar}$ dates available on the Guérande leucogranite range from ca. 307 to ca. 303 Ma (Le Hébel, 2002). Consequently, based on the closure temperature for the muscovite ${ }^{40} \mathrm{Ar} /{ }^{39} \mathrm{Ar}$ geochronometer (Harrison et al., 2009), we assumed that the Guérande intrusion reached a temperature of $450 \pm 100^{\circ} \mathrm{C}$ at $300 \pm 10 \mathrm{Ma}$ and used 
these data as a constraint in the QTQt model. As suggested by the unimodal distribution of the fission track lengths (Fig. 12b, c, d), the Guérande leucogranite shows a monotonous cooling through the partial annealing zone (PAZ: $60-120^{\circ} \mathrm{C}$ ) at a rate of about $3^{\circ} \mathrm{C}$ per Ma from ca. 195 to $175 \mathrm{Ma}$. Following this initial exhumation phase, the samples remained below $60^{\circ} \mathrm{C}$ at or near the surface.

\section{Discussion}

\subsection{Fluid-rock interaction in the Guérande leucogranite}

In Figure 11 , the $\delta^{18} \mathrm{O}$ values of all the quartz and most of the whole-rock and feldspar samples from the Guérande leucogranite samples display a correlation with the latitude. This evolution can in part be explained by the fractional crystallization process proposed by Ballouard et al. (2015). Indeed, the most differentiated samples (apical zone facies) are located in the northwestern part of the intrusion and the segregation of low- $\delta^{18} \mathrm{O}$ biotite may increase the $\delta^{18} \mathrm{O}$ of the evolving melt. Yet, Ballouard et al. (2015) showed that the chemical variation between the samples with the lowest and highest $\mathrm{SiO}_{2}$ contents from the Guérande leucogranite can be explained by a fractionation of $15-30$ wt.\% of a cumulate composed of $0.44 \mathrm{Kfs}$ (potassic feldspar), $0.31 \mathrm{PI}$ (plagioclase-An20), $0.21 \mathrm{Bt}$ (biotite) and $0.04 \mathrm{Ap}$ (apatite). Consequently, if the initial magma had a $\delta^{18} \mathrm{O}$ value of $12.3 \%$ (e.g. sample GUE-17), the assemblage $0.75 \mathrm{Fs}$ (Feldspar) $+0.21 \mathrm{Bt}+0.04 \mathrm{Ap}$ would have had a $\delta^{18} \mathrm{O}$ value of $11.4 \%$, taking a feldspar value of $12 \%$ ( $0.3 \%$ o lower than the whole-rock) and considering equilibrium isotopic fractionation factors between the granitic melt, feldspar, biotite and apatite at $600^{\circ} \mathrm{C}$ (Zheng, 1993 and Valley, 2003). This indicates that in order to increase the $\delta^{18} \mathrm{O}$ of the melt from 12.3 to $13.5 \%$, such as observed in the whole-rock values from our samples (Fig. 11), 55 wt.\% of the cumulate would have to be separated from the granitic melt, a value that is too high when compared to our prediction. Alternatively, Ballouard et al. (2015) demonstrated that the apical zone of the Guérande leucogranite experienced a pervasive magmatichydrothermal alteration. Given that the $\mathrm{Sr}$ and $\mathrm{Nd}$ isotopic compositions of the Guérande leucogranite do not favor source heterogeneities or country rock assimilation (Ballouard et al., 2015), the high $\delta^{18} \mathrm{O}$ values of the samples may relate to this hydrothermal event. This process was already 
proposed by Dubinina et al. (2010) to explain the high $\delta^{18} O$ values recorded in the apical zone samples from the Miocene leucogranites from the Caucasian mineral water region (Russia). The results of the geochemical modeling performed by these authors indicated that a change of up to $1 \%$ in the $O$ isotope composition of a cooling granitic rock can occur, as a result of the interaction with exsolved magmatic fluids in isotopic equilibrium with the granitic melt, if this rock was localized in the zones that crystallized at an early stage (i.e. the outer zone of the intrusion).

Whereas the quartz retained its magmatic oxygen isotope composition $\left(\delta^{18} \mathrm{O}_{\mathrm{Qtz}}=12.6-14.5\right.$ $\%$ ), the whole-rock and feldspars of four samples from the north of the Guérande leucogranite (Fig. 11) have low $\delta^{18} \mathrm{O}$ values $\left(\delta^{18} \mathrm{O}_{\mathrm{WR}}=9.7-11.6 \% ; \delta^{18} \mathrm{O}_{\mathrm{Fs}}=8.3-9.3 \%\right.$ ). The isotopic disequilibrium between quartz and feldspar recorded in these low $\delta^{18} \mathrm{O}$ samples argue for an open system alteration (Gregory and Criss, 1986) with a sub-solidus interaction between the feldspar and a low $\delta^{18} \mathrm{O}$ fluid. Indeed, close to the granite solidus temperature (about $600^{\circ} \mathrm{C}$ ), an exsolved magmatic fluid in equilibrium with a quartz with a $\delta^{18} \mathrm{O}$ of $14 \%$ (Fig. 11) would have a $\delta^{18} \mathrm{O}$ of around $12 \%$ (Zheng, 1993), and the feldspar is always enriched in ${ }^{18} \mathrm{O}$ with regard to $\mathrm{H}_{2} \mathrm{O}$ (by about 0.6 to $8 \%$ o for temperature from 600 to $200{ }^{\circ} \mathrm{C}$, respectively; Zheng, 1993). Thus, the only possibility to lower the $\delta^{18} \mathrm{O}$ of feldspar (from $\sim 12$ to $9 \%$ in our samples, Fig. 11) during hydrothermal alteration is to involve a low $\delta{ }^{18} \mathrm{O}$ fluid. A temperature of alteration cannot be estimated using a feldspar- $\mathrm{H}_{2} \mathrm{O}$ equilibrium, as the isotopic composition of the water and the fluid/rock ratio remains unknown. However, it is obvious that this fluid alteration event occurred when the granite was still at depth as the degree of fractionation of $\mathrm{O}$ isotope is anti-correlated with temperature. In fact, at a low temperature of $50^{\circ} \mathrm{C}$, the $\mathrm{O}$ isotope fractionation value between feldspar and water $\left(\Delta^{18} \mathrm{O}_{\text {feldspar-H2O }}\right)$ is high and around $25 \%$ (Zheng, 1993). This fact precludes a decrease in the feldspar $\delta^{18} \mathrm{O}$ values (i.e. from $12 \%$ to $9 \%$ ) during the fluid-feldspar interaction, as observed in the altered granite samples, even if we consider a fluid with a $\delta^{18} \mathrm{O}$ value down to $-10 \%$. The different behavior between quartz and feldspar is consistent with the fact that quartz is believed to be more resistant to an oxygen isotope exchange with fluids than feldspar (e.g. Gregory and Criss, 1986). 
The most probable source for an input of low- $\delta^{18} \mathrm{O}$ fluid is oxidizing meteoric waters. Indeed, this part of the Hercynian belt was likely above sea level at ca. $300 \mathrm{Ma}$ (Lemarchand et al., 2012), and meteoric water infiltration at depth is well documented in the South Armorican Massif during the regional deformation from ca. 315 to 300 Ma (Tartèse and Boulvais, 2010; Tartèse et al., 2012; Lemarchand et al., 2012, Tartèse et al., 2013). Furthermore, as evidenced by Gapais et al. (1993) and Ballouard et al. (2015), the Guérande granite was emplaced syntectonically along an extensional deformation zone and is characterized by the presence of $S / C$ and mylonitic extensional fabrics at the apex. All these features represent permeable planar discontinuities that can facilitate downward fluid infiltration.

To summarize, the Guérande leucogranite recorded two different events of fluid-rock interactions. The first at high temperature, already described by Ballouard et al. (2015), is recorded at the apical zone of the intrusion by an increase in incompatible elements such as Cs and Sn, secondary muscovitization and possibly an increase in the quartz and feldspar $\delta^{18} \mathrm{O}$ values. This magmatic-hydrothermal event likely occurred during the emplacement of the Guérande leucogranite at ca. $310 \mathrm{Ma}$. The second fluid-rock interaction event, which took place at a lower temperature and in relation with a probable meteoric-derived fluid, mostly affected the deformed part of the northern side of the leucogranite and is evidenced by low- $\delta^{18} \mathrm{O}$ feldspar and whole-rock values. As proposed by Tartèse and Boulvais (2010) for the neighboring Questembert leucogranite (Fig. 1), the pervasive S/C structures that affected the roof of the Guérande leucogranite likely facilitated the infiltration of oxidizing meteoric fluids at depth. The implication of these two hydrothermal events on the uranium mobility in the Guérande leucogranite and the formation of $U$ mineralization will be discussed in the following section.

\subsection{U leaching in the Guérande leucogranite}

The $U$ distribution in the Guérande leucogranite samples does not correlate with hydrothermallyimmobile markers of fractional crystallization such as $\mathrm{SiO}_{2}$, La or Th (Fig. 10b). Therefore, it is unlikely that the $U$ distribution was solely controlled by magmatic processes. In the $U$ vs. Cs (Fig. 13a), U vs. 
Sn (Fig. 13b) and U vs. K/Rb (Fig. 13c) diagrams, U shows a complex behavior with two different trends. The first trend mostly concerns the samples from the root and transitional facies whereas the second trend exclusively concerns the samples from the apical zone (Fig. 2).

In the trend for the root and transitional facies (Fig. 13), $U$ is correlated with both Cs and Sn: $U$ content increases from 2 to $7 \mathrm{ppm}$ whereas Cs and Sn contents increase from 5 to $30 \mathrm{ppm}$ and 3 to $20 \mathrm{ppm}$, respectively. In contrast, the $\mathrm{K} / \mathrm{Rb}$ ratio is anti-correlated with $\mathrm{U}$ and decreases from 200 to 150. The positive correlation between $U$ and Cs (Fig. 13a) or $U$ and Sn (Fig. 13b) could be explained by a common magmatic evolution as $\mathrm{U}, \mathrm{Cs}$ and $\mathrm{Sn}$ all behave as incompatible elements in a peraluminous melt. However, the increase in the Cs content from 5 to $30 \mathrm{ppm}$ can hardly be explained solely by fractional crystallization as it would require about $85 \%$ of mineral fractionation, an amount far higher than the $15-30 \%$ mineral fractionation estimated from geochemical modeling (Ballouard et al., 2015), and therefore likely implies some interaction with orthomagmatic fluids. Such correlations between $\mathrm{U}$ and incompatible elements such as $\mathrm{Cs}, \mathrm{Sn}$ or Rb have already been observed in the St-Sylvestre peraluminous granite by Friedrich et al. (1987) and were attributed to the behavior of $U$ during magmatic-hydrothermal processes. It is known that the simultaneous transport of $U$ and elements such as $\mathrm{Sn}$ in the same fluid is not common because they generally display an opposite behavior, notably because their affinity toward the fluid depends on different oxygen fugacities. In fact, in a hydrothermal fluid, a low oxygen fugacity $\left(\mathrm{fO}_{2}\right.$ below the Ni-NiO buffer; i.e. a magmatic fluid exsolved from a peraluminous magma) favors the transport of $\mathrm{Sn}$ whereas a high oxygen fugacity ( $\mathrm{fO}_{2}$ above the hematite-magnetite buffer; i.e. a surface-derived hydrothermal fluid) favors the transport of $U$ (Dubessy et al., 1987). However, the solubility of $U$ in reducing magmatic fluid exsolved from a peraluminous melt increases greatly if these fluids are enriched in chlorine (Peiffert et al., 1996). Therefore, we suggest that the first evolution trend (Fig. 13) represents a concomitant enrichment in $\mathrm{U}, \mathrm{Sn}, \mathrm{Cs}$ and a decrease in the $\mathrm{K} / \mathrm{Rb}$ ratio through combined fractional crystallization and an interaction with late-magmatic fluids. 
In the apical zone facies trend (Fig. 13), the $U$ contents remain rather low, below $4 \mathrm{ppm}$, whereas the Cs and Sn contents increase from 20 to $100 \mathrm{ppm}$ and the $\mathrm{K} / \mathrm{Rb}$ values decrease from 150 to 75 . The difference in $U$ contents between the apical zone in the northwestern part and the root in the southwestern part can also be observed on the airborne radiometric map (Fig. 10a). The hypothesis which can be proposed to explain the low $U$ contents of the apical zone is that this area has been depleted by the dissolution of magmatic uranium oxides from evolved samples during a late fluid circulation event, at depth or during surface weathering. Indeed, the samples from both the root and transitional facies and the apical zone facies share the same magmatic history controlled by fractional crystallization (Ballouard et al., 2015), so the highest uranium content was expected in the highly evolved samples from the apical zone. Uraninite, which is one of the most easily leachable Ubearing mineral (e.g. Cuney, 2014), has not been directly observed in our samples but its presence has been reported by Ouddou (1984) in the northwestern part of the intrusion. In peraluminous magmas, uraninite typically crystallizes when bulk $U$ contents reach around $10 \mathrm{ppm}$ (Peiffert et al., 1996). Therefore, the maximum U content of 8 ppm observed in the studied Guérande samples does not seem to be representative of the initial value. Indeed, it is likely that values higher than $10 \mathrm{ppm}$ have been reached by the most evolved samples during the magmatic-hydrothermal evolution of the intrusion, following the trend defined by the root and transitional facies in the $U$ vs. Cs diagrams for example (Fig. 13a), and that later uraninite alteration at depth or during surface weathering lowered the $U$ contents of the apical zone facies. Furthermore, most of the samples localized near the apical zone present $\mathrm{Th} / \mathrm{U}$ ratios below or equal to $1(\mathrm{Th} / \mathrm{U}=0.3-1.3$; Fig. 10b). Taking into account the possibility that some uranium has been leached out from these rocks, this implies that the initial (pre-leaching) ratios were even lower than that. Such low $T h / U$ values suggest that most of the uranium was incorporated into uranium oxides (up to $80 \%$ for $\mathrm{Th} / \mathrm{U}=1$ ) at the expense of refractory U-bearing minerals such as monazite or zircon (Friedrich et al., 1987).

As the solubility of uraninite in fluids is highly dependent on the oxygen fugacity (Dubessy et al., 1987), it is unlikely that the leaching of uranium oxide at the apical zone of the intrusion occurred 
during the interaction with reducing high temperature Cs- and Sn-rich fluids. This leaching of $U$ could have occurred either during surface weathering or at depth during a hydrothermal alteration event with oxidizing surface-derived fluids, similarly to what has been documented in the neighboring Questembert granite (Tartèse et al., 2013). A sub-solidus interaction with oxidizing fluids of meteoric origin is recorded via oxygen isotope analyses in samples from the northern edge of the Guérande leucogranite and three of these samples belong to the apical zone facies. This result suggests that even if surface weathering likely contributes to some $U$ leaching at the apex of the granite, the subsolidus alteration event at depth with surface-derived fluids recorded in the deformed facies likely liberated substantial amounts of uranium. Finally, the uranium behavior in the late magmatic/hydrothermal processes observed in the Guérande leucogranite, such as chloritization or albitization (Fig. 2), is unclear and no loss or gain of $U$ has been noticed.

\subsection{Metallogenesis}

\subsubsection{Mineralizing fluids}

In the Pen Ar Ran deposit, the study of the primary fluid inclusions from a quartz comb associated with a uranium oxide-bearing vein provides precious information about the chemical and physical properties of the uranium mineralizing fluid.

Raman and microthermometric analyses indicate low salinity fluids with a $\mathrm{NaCl}$ eq. content between 1 and 6 wt.\% in the liquid (Fig. 8a). The fluid inclusions contain $\mathrm{H}_{2} \mathrm{O}-\mathrm{NaCl}-\mathrm{O}_{2}-\mathrm{H}_{2}-\left(\mathrm{N}_{2}\right)($ Table 3) and display variable homogenization temperatures $\left(T_{h}\right)$, ranging from 250 to $450^{\circ} \mathrm{C}$ (Fig. $8 \mathrm{~b}$ ). In Figure $8 \mathrm{c}$, the inclusions homogenizing in the vapor phase $\left(T_{h} \sim 400-450{ }^{\circ} \mathrm{C}\right)$ generally display a higher salinity ( $3-6 \mathrm{wt} . \% \mathrm{NaCl}$ eq.) than those homogenizing in the liquid phase (Th $350-400$; salinity $1-4$ wt.\% $\mathrm{NaCl}$ eq.) and this observation could suggest a mixing between a low temperature-low salinity fluid and a high temperature-moderate salinity fluid. A mixing process between meteoric-derived and basinal fluids has been invoked for the genesis of numerous uranium deposits of the EHB such as in the French Massif Central (Turpin et al., 1990) or Bohemian Massif (Kř́bek et al. 2009; Dolníček et al., 2013). For the Pen Ar Ran deposit, the low salinity of the fluid inclusions (1-6 wt.\% eq. $\mathrm{NaCl}$ ) suggests that a fluid with a meteoric origin was involved in the genesis 
of the mineralization, but does not imply the involvment of basinal brines. In contrast, the elevated $T_{h}$ measured on the inclusions suggest a contribution of deep fluids with probably metamorphic origins. On the other hand, $\mathrm{O}_{2}$ and $\mathrm{H}_{2}$ gases are both characteristic of the radyolisis of water that has been in contact with uranium minerals (Dubessy et al., 1988). Their presence in fluid inclusions can likely result from the heterogenous entrapment of radiolytic $\mathrm{O}_{2}$ and $\mathrm{H}_{2}$ and this process could account for the variability in the measured $T_{h}$ (Derome et al., 2005). In Figure $8 d, T_{h}$ correlates with the degree of volatile filling in the inclusion sugesting that the highest $T_{h}$ are mostly disturbed by radiolytic gases and that the lowest $T_{h}\left(250-350^{\circ} \mathrm{C}\right)$ should be taken as the best estimate for the trapping temperature. As a consequence, the fluid inclusion data alone does not allow us to unambiguously interpret the highest $T_{h}$ measured in the fluid inclusions as indicating a mixing of fluids with various origins or the entrapment of radiolytic $\mathrm{H}_{2}$ and $\mathrm{O}_{2}$. In any case, both hypothesis are in agreement with the contribution of low salinity meteoric fluids with temperatures in the range of $250-350^{\circ} \mathrm{C}$. These temperatures are relatively high when compared to other vein type deposits from the French Hercynian belt, which are generally in the range of $150-250^{\circ} \mathrm{C}$ (Cathelineau et al., 1990), and therefore, reflect specific conditions for the Pen Ar Ran mineralization.

Around $300 \mathrm{Ma}$ ago (first mineralizing event in the Pen Ar Ran deposit, see section 5.3.2 for details), the metavolcanics that host the Pen Ar Ran uranium mineralization were part of the brittle upper crust and were already below $450^{\circ} \mathrm{C}$, based on the muscovite ${ }^{40} \mathrm{Ar}-{ }^{39} \mathrm{Ar}$ dates of $311.8 \pm 0.5 \mathrm{Ma}$ and $313.4 \pm 0.4$ Ma obtained on the porphyroids from the Piriac graben (Le Hébel, 2002) and the closure temperature of the muscovite ${ }^{40} \mathrm{Ar}^{39}{ }^{39} \mathrm{Ar}$ geochronometer (Harrison et al., 2009). However, this period around $300 \mathrm{Ma}$ ago marks the end of the extension regime in the South Armorican Massif (e.g. Gapais et al., 1995), and notably the end of the ductile deformation in the Guérande leucogranite, as attested by muscovite ${ }^{40} \mathrm{Ar}-{ }^{39} \mathrm{Ar}$ dates of $304 \pm 0.6 \mathrm{Ma}$ and $303.6 \pm 0.5 \mathrm{Ma}$ on a S/C granite and on a sheared granite from the nortwestern part of the intrusion, respectively (Le Hébel, 2002). The exhumation of the lower crust in the South Armorican Massif during extension likely induced an increase in the geothermal gradient at a regional scale. Moreover, this period was 
accompanied by a late magmatic event at depth in the Guérande region as demonstrated by the emplacement of leucogranitic dykes at $302.5 \pm 2.0$ Ma (Ballouard et al., 2015), which also likely contributed to this abnormal heat flow in the environment of the deposit. Finally, according to the apatite fission track thermal modeling, the Guérande leucogranite was still at a temperature above $120^{\circ} \mathrm{C}$, so at a depth greater than about $4 \mathrm{~km}$ (for a geothermal gradient of $30^{\circ} \mathrm{C} / \mathrm{km}$ ), $200 \mathrm{Ma}$ ago (Fig. 12).

\subsubsection{Timing of the uranium mineralization}

The U-Pb analyses performed on the uranium oxide samples from the Pen Ar Ran and MétairieNeuve deposits revealed three different events (Fig. 9) dated at $296.6 \pm 2.6 \mathrm{Ma}$ (PAR-spherulitic: core), $286.6 \pm 1.0 \mathrm{Ma}$ (Métairie-Neuve) and $274.6 \pm 0.9 \mathrm{Ma}$ (PAR-pseudo-spherulitic and PARprismatic), respectively. The low content in $\mathrm{FeO}$ and $\mathrm{SiO}_{2}$ of the uranium oxides $\mathrm{Ur} 1$ (Table 2) and the concordance of most of the U-Pb analyses (Fig. 9) suggest that these uranium oxides did not undergo a significant post-crystallization alteration and that the concordia dates obtained in this study reflect the crystallization age of the uranium-oxides.

In the uranium oxide "PAR-spherulitic" sample, the $\mathrm{CaO}$ content increases from the core to the rim of the spherules and is inversely correlated with the PbO content (Fig. 6a). This inverse correlation is likely primary, reflecting the concentric zoning displayed by the spherules in the BSE images and could account for the lower mean atomic mass (darker color) of the rims compared to the cores of the spherules (Fig. 5a). The REE contents of the spherules ( $\Sigma$ REE) also decrease from the core to the rim (Table 2 and Fig. $6 \mathrm{~b}$ ) and likely reflect the composition of the mineralizing fluid. The saddle shape displayed by some REE patterns (Fig. 6b) is however not specific of the location of the analyses. U-Pb analyses performed on the cores of the spherules allow to calculate their crystallization at $296.6 \pm 2.6 \mathrm{Ma}$ (Fig. 9a). The two sub-concordant analyses performed on the rim of the spherules yield apparent ${ }^{206} \mathrm{~Pb} /{ }^{238} \mathrm{U}$ dates of $270.6 \pm 2.4 \mathrm{Ma}$ and $282.7 \pm 2.8 \mathrm{Ma}$ (Figs. 5a and 9a) that may reflect slight $\mathrm{Pb}$ loss. 
The two other samples from the Pen Ar Ran deposit ("PAR-pseudo-spherulitic" and "PARprismatic") display major element compositions ( $\mathrm{CaO}$ and PbO contents; Fig. 6a) and REE patterns (Fig. 6c) mostly comparable with those from the "PAR-spherulitic" sample. In particular, the REE patterns and REE concentrations obtained on the rim of the spherules of the "PAR-spherulitic" sample are almost identical to those obtained on the "PAR-pseudo-spherulitic" sample, likely reflecting a similar mineralization condition. U-Pb analyses on the "PAR-pseudo-spherulitic" and "PAR-prismatic" samples allow to define their crystallization age at $274.6 \pm 0.9 \mathrm{Ma}$.

As a consequence, we suggest that at least two $U$ mineralizing events occurred at Pen Ar Ran: a first one at $296.6 \pm 2.6 \mathrm{Ma}$ and a second one at $274.6 \pm 0.9 \mathrm{Ma}$. These two different events, separated by са. $20 \mathrm{Ma}$, are surprising but in fact consistent with the description of Cathelineau (1981) who described that the prismatic facies postdated the spherulitic facies in the Pen Ar Ran deposit. The $\mathrm{Pb}$ loss recorded by the rims on some of the spherules from the "PAR-spherulitic" sample, which yield apparent ${ }^{206} \mathrm{~Pb} /{ }^{238} \mathrm{U}$ dates of $270.6 \pm 2.4 \mathrm{Ma}$ and $282.7 \pm 2.8 \mathrm{Ma}$, possibly occurred during the second mineralizing event.

The concordia age of $286.6 \pm 1.0 \mathrm{Ma}$ obtained on the uranium oxides from the Métairie-Neuve deposit probably dates another mineralizing event. The REE patterns of the samples suggest different conditions for the mineralization than in the Pen Ar Ran deposit. For example, the positive Eu anomaly could reflect more oxidizing conditions at the moment of uranium precipitation. Indeed, the much larger ionic radius of $\mathrm{Eu}^{2+}$, compared to $\mathrm{Eu}^{3+}$, limits the substitution of $\mathrm{Eu}^{2+}$ for $\mathrm{U}^{4+}$ in the uranium oxide structure. Therefore, the Eu anomaly in uranium oxide could be a good proxy for oxygen fugacity in the $\mathrm{U}$ precipitation environment as it reflects the oxidation state of Eu (Fryer and Taylor, 1984; Eglinger et al., 2013).

On a larger scale, the dates of ca. $285 \mathrm{Ma}$ and ca. $275 \mathrm{Ma}$ obtained for the uranium mineralizing events in the Guérande district (Métairie-Neuve and Pen Ar Ran deposits) are comparable with those obtained by Cathelineau et al. (1990) in other vein type deposits from the Mortagne district in the South Armorican Massif (Fig. 1) and French Massif Central with a major stage of U mineralization 
between 290 and $260 \mathrm{Ma}$. In the Bohemian massif and Black Forest, most vein-type uranium deposits are also Permian in age (e.g. Hofmann and Eikenberg, 1991; Velichkin and Vlasov, 2011 and reference therein).

5.4. Is the Guérande leucogranite the source for the uranium of the Pen Ar Ran deposit? Based on the REE patterns of uranium oxides from the Pen Ar Ran mineralization, Bonhoure et al. (2007) proposed that the metavolcanics of the Piriac graben (Vendée porphyroids; Fig. 3) were the likely source for the uranium concentrated in this deposit. Our study does not favor this hypothesis as we did not obtain the same REE patterns as these authors (i.e. no positive anomaly in Sm, Eu and Gd in our REE patterns; Fig. 6). Because of this difference, we tested our LA-ICP-MS analytical protocole using an $\mathrm{UO}_{2}$ reference material (Mistamisk, Lach et al., 2013), and did not notice any significant difference between the measured REE contents and the reference ones. Consequently, we believe that our data are accurate.

Moreover, the Th/U ratios obtained on the Vendée porphyroids using radiometric data and ICPMS analyses are rather high, between 2 and 5 (Fig. 10b). These Th/U ratios favor the crystallization of refractory U-bearing minerals at the expense of uranium oxides from which $U$ is more easily leachable in the presence of hydrothermal fluids (Friedrich et al., 1987; Cuney, 2014). Also, the Th/U ratios of the porphyroids from the Piriac graben (Th/U between 2 and 5) are comparable with those obtained for the same Ordovician metavolcanics elsewhere in the South Armorican Massif (Th/U between 2 and 15; Fig. 10b), which does not favor $U$ leaching from the Guérande district metavolcanics. The HP-LT metamorphism, which affected the Vendée porphyroid formation around 360 Ma (Bosse et al., 2005; Le Hébel, 2002), also preclude the presence of easy leachable volcanic glass with free $U$ in the metavolcanics at ca. $300 \mathrm{Ma}$. It should be noted that the presence of uraninite was never described for these porphyroids. Finally, the fluid inclusion analyses and stable isotope characterization of the Vendée porphyroid formation at a regional scale, including the Piriac locality (Le Hebel et al., 2007), indicates that this unit was deformed within a system closed to fluids 
at the time of the HP-LT metamorphism and during the Guérande leucogranite emplacement, precluding significant chemical alteration of these porphyroids.

In the black shales, the Th/ $U$ ratios between 0.5 and 2 (Fig. 10b) point to the presence of free $U$ but the highly reducing character of these lithologies, combined with the effect of the HP-LT metamorphism, preclude a high U mobility.

In the Guérande leucogranite, the low Th concentrations reflect the magmatic fractionation of monazite and zircon (see for example the good correlation of $\mathrm{Th}$ with $\mathrm{La}, \mathrm{Zr}$ and $\mathrm{SiO}_{2}$ documented by Ballouard et al., 2015, their figure 9). This magmatic evolution likely induced the increase in the $U$ content in the differentiated melts and led to uraninite saturation as only a limited amount of uranium is incorporated in monazite and other accessory minerals such as zircon or apatite (Cuney et al., 2014; Friedrich et al., 1987). However, the actual U content of the Guérande leucogranite is lower than what is expected for uraninite saturation. One way to understand this apparent paradox is to consider that uraninite actually crystallized in the differentiated melts when the uranium content reached around $10 \mathrm{ppm}$ or more (some uraninite grains have been actually observed in a drill core, see above), but uraninite was then dissolved, likely by infiltrating fluids, and a significant fraction of the bulk uranium leached out from the granite. In this scenario (magmatic evolution overprinted by hydrothermal alteration and surface weathering), the Th/U ratios may have widely varied, resulting in the measured low and erractic values $(0.2<$ Th/U $<2.1$; ICP-MS data from Ballouard et al., 2015; Fig. 10b).

Several lines of evidence favor the Guérande leucogranite as the main source for the uranium of the Pen Ar Ran deposit:

(1) The U airborne radiometric map (Fig. 10a) and trace element geochemistry (Fig. 13) suggest that some $U$ has been leached out from the highly differentiated facies from the apical zone of the intrusion.

(2) Oxygen isotope analyses show that a sub-solidus alteration event with surface-derived fluids affected the deformed facies from the roof of the intrusion when this granite was still at depth 
(Fig. 11). These oxidizing fluids were likely able to dissolve the magmatic uranium oxides and to liberate U (Dubessy et al., 1987).

(3) The REE patterns obtained on the uranium oxides from the Pen Ar Ran deposit (Figs. 6b and 6c) are overall comparable with the patterns of the uranium oxides from other vein-type deposits from the French Hercynian belt where uranium is expected to originate from the leaching of the surrounding leucogranites (Mercadier et al., 2011). The saddle shape displayed by LREE on some spectra obtained on the "PAR-spherulitic" sample (Fig. 6b) and two samples from Métairie-Neuve (Fig. 6d) point to peculiar REE fractionation processes likely resulting from a variation of the physical-chemical conditions in the mineralizing fluids or in the $U$ precipitation environment. The parameters controling the solubility of REE in aqueous fluids are various (temperature, oxygen fugacity, presence of ligands...) and it is difficult to precise which one is responsible for this peculiar LREE behavior. Moreover, the interaction of the mineralizing fluid with various lithologies such as leucogranites, micaschists, metavolcanics and black shales, in which REE can be host in different mineral phases, could induce specific fractionation between REE.

(4) The U-Pb dating on uranium oxides from the Pen Ar Ran deposit revealed that a first mineralizing event occurred at $296.6 \pm 2.6 \mathrm{Ma}$. This event was sub-synchronous with an early hydrothermal circulation event (constrained by muscovite ${ }^{40} \mathrm{Ar}^{39}{ }^{39}$ dates obtained on deformed granite samples and on a quartz vein from the apex; Le Hébel, 2002) and with the emplacement of late leucogranitic dykes in the Guérande leucogranite at ca. 303 Ma (Ballouard et al., 2015; Fig. 14).

(5) Fluid inclusions analyses on a quartz comb associated with an uranium oxide-bearing vein from the Pen Ar Ran deposit argue for low-salinity mineralizing fluid, consistent with the involvment of meteoric fluids (Fig 8a). The elevated estimated fluid trapping temperatures $\left(250-350^{\circ} \mathrm{C}\right.$ ) reflect an abnormal heat flux in the near environment of the deposit, possibly reflecting lower crust exhumation during regional extension and magmatic activity at depth, as reflected by the emplacement of the leucogranitic dykes at ca. $303 \mathrm{Ma}$.

5.5. Mass balance calculation 
The oxygen isotope, radiometric data and trace element analyses in the Guérande leucogranite combined with the geochemical and geochronological characterization of the uranium mineralization, lead us to the hypothesis that the highly evolved deformed facies from the apical zone of the intrusion represents a likely source for the $U$ found in the surrounding deposits. In the apical zone of the intrusion, pervasive solid-state deformation is mostly observed to the north of the graben in the harbor of Piriac-sur-Mer (sample GUE-9, Fig. 2). In this area, we can consider, based on cartographic criteria, that the extensional deformation zone, with an approximate thickness of $100 \mathrm{~m}$ and a minimum extension of $2 \times 10^{6} \mathrm{~m}^{2}$, has a minimum volume of $2 \times 10^{8} \mathrm{~m}^{3}$. If we consider that this volume had an initial uranium content of $20 \mathrm{ppm}$ (as attested by the drill core sample of Ouddou, 1984), and that $50 \%$ of this uranium was hosted by uranium oxides, this volume represents an initial available mass of $U$ of about $5400 \mathrm{t}$. Around $600 \mathrm{t}$ of $U$ have been extracted from the Pen $\operatorname{Ar}$ Ran deposit which is located structurally above the apical zone of the intrusion (Figs. 2 and 3). Therefore, this mass balance estimate suggests that most, if not all, of the $U$ extracted from the Pen $\operatorname{Ar}$ Ran deposit could have originated from the leaching of the highly evolved deformed facies of the apical zone of the Guérande leucogranite.

\subsection{Uranium mineralizing process}

In Figure 14, we have reported the major events that occurred in the Guérande district from 310 to $270 \mathrm{Ma}$. These events and their implications for the uranium metallogenesis are also represented as a drawing in Figure 15.

At ca. $310 \mathrm{Ma}$, the Guérande leucogranite was emplaced in a mainly top to the north extensional deformation zone (Fig. 2). This tectonic-magmatic event was contemporaneous with the beginning of a synconvergence crustal thinning in the southern part of the Armorican Massif and with dextral wrenching along the South Armorican Shear Zone (Gumiaux et al., 2004; Gapais et al., 2015) (Fig. 1). The main N-S stretching direction in the Guérande area is different from the overall W-E stretching direction recorded in the South Armorican domain and could be the consequence of a regional subhorizontal flattening regime (Ballouard et al., 2015; Gapais et al., 2015). This crustal extension event, 
which led to the development of core complex cored by migmatites and syntectonic leucogranites, such as the Saint-Nazaire migmatites and the Guérande leucogranite (Fig. 2), was likely accommodated by brittle extensional tectonics in the upper crust as tentatively illustrated in Figure 15. During the emplacement of the Guérande leucogranite, fractional crystallization and interaction with late magmatic fluids allowed for the crystallization of magmatic uranium oxides at the apical zone of the intrusion.

At ca. $300 \mathrm{Ma}$, the deformation was still active in the Guérande region, as evidenced by the muscovite ${ }^{40} \mathrm{Ar}^{-39} \mathrm{Ar}$ dates of $304 \pm 0.6 \mathrm{Ma}$ and $303.6 \pm 0.5 \mathrm{Ma}$ obtained on a S/C granite and a sheared granite, respectively (Le Hébel, 2002), but with probably a transition from a ductile to a brittle regime. At a regional scale, this date also marks the end of the ductile deformation along the South Armorican Shear Zone and the Quiberon detachment (Gapais et al., 2015) (Fig. 1). In the Guérande region, meteoric fluids could have percolated into the fault zones and in the deformed facies of the leucogranite as the $\mathrm{S} / \mathrm{C}$ structures likely facilitate the infiltration of surface derived waters at depth (e.g. Tartèse and Boulvais, 2010). Moreover, the isotopic study of Lemarchand et al. (2012) on syntectonic quartz veins along the South Armorican Shear Zone suggests that meteoric fluids were involved in their formation, and that a significant relief in this part of the Armorican Massif at this period likely facilitated meteoric fluid circulations at depth. In Figure 15, these oxidizing surface derived fluids became enriched in $U$ by leaching the magmatic uranium oxides from the evolved facies of the apical zone of the Guérande leucogranite. When these fluids percolated in the structures at the contact between the metavolcanics and reducing black shales, uranium was precipitated. In the Pen Ar ran deposit, the U mineralization filled brittle structures which correspond to the riedel or tension gashes of the $\mathrm{N} 110^{\circ}$ strike-slip faults (Cathelineau et al., 1981) (Fig. 4), showing that the mineralizing processes were deeply linked with the tectonic activity. The heat flux that allows for the convection of these fluids was probably provided by late magmatism, as evidenced by the intrusion of leucogranitic dykes at about $300 \mathrm{Ma}$, and at a larger scale, by the 
exhumation of a hot lower crust during the late-orogenic extension of this part of the Hercynian Belt (e.g. Gapais et al., 2015).

The recognition that $\mathrm{U}$ mineralizing events occurred until ca. $275 \mathrm{Ma}$ in the Guérande district suggests that oxidizing surface-derived fluids have continued to percolate, probably by pulse, in the Guérande leucogranite during a long time period of ca. $25 \mathrm{Ma}$ and that a discreet extensional tectonic activity was present until the middle Permian. Tectonic and hydrothermal events have not yet been documented in this part of the Armorican Massif during the Lower Permian but apatite fission track analysis reveals that the Guérande leucogranite was still at depth at that time (Fig. 12). Moreover, lithospheric extensional events are well described during this period, for example in the French Massif Central, and induced the coeval exhumation of metamorphic domes and the formation of Late Carboniferous to Permian continental sedimentary basins with a dominant half-graben structural style (e.g. Van Den Driessche and Brun, 1989, 1992; Faure, 1995).

On a continental scale, the Permian period hosts the main $U$ mineralizing events for the EHB (Fig. 16) and most $U$ ore deposits in the Moldanubian zone or terranes with Gondwanian affinities are sub-synchronous or postdate, up to $35 \mathrm{Ma}$, the end of peraluminous leucogranitic magmatism. One hypothesis is that Carboniferous peraluminous leucogranites, which are characterized by high heat production due to their high content in radioactive elements (Vigneresse et al., 1989; Jolivet et al., 1989), can maintain the convection of surface derived hydrothermal fluids at depth several million years after their emplacement as long as these intrusions remain buried at depth. Moreover, the Permian period in Europe is characterized by an abnormal heat flux in the mantle, evidenced, for example, by the emplacement of the Cornubian Batholith in southwest England from $295 \mathrm{Ma}$ to $275 \mathrm{Ma}$ (Chen et al., 1993) and the emplacement of post-orogenic granitoids in Iberia from 310 to 285 Ma (Fernández-Suárez et al., 2000; Gutiérrez-Alonso et al., 2011) (Fig. 16). This abnormal mantellic heat flux may have helped maintain an elevated geothermal gradient.

5.7. Implication for the Mesozoic evolution of the Armorican Massif 
The apatite fission track analysis shows that the Guérande leucogranite experienced a slow cooling from 120 to $60^{\circ} \mathrm{C}(\mathrm{PAZ})$ from 210 to $175 \mathrm{Ma}$ and that this intrusion remained below $60^{\circ} \mathrm{C}$ after $175 \mathrm{Ma}$ (Fig. 12). The exhumation of the Guérande leucogranite between the Upper Triassic and lower Jurassic could be related to the extensional crustal deformation events that have been well recorded in the sediments of the Paris Basin (e.g. Guillocheau et al., 2000). Based on a detailed mapping of planation surfaces in the Armorican Massif, Bessin et al. (2014) showed that at least two major burring and denudation phases occurred in the Armorican Massif during the MesozoicCenozoic: the burial during the Middle to Upper Jurassic time was followed by a denudation episode during the early Cretaceous then a burial during late Cretaceous was followed by a denudation event from the latest Cretaceous to Eocene times. These authors also suggest that the burial depths of the sediments during the Middle to Upper Jurassic and Late Cretaceous times were shallow due to the lack of a significant volume of Early Cretaceous and Cenozoic siliciclastic sediments in the basins surrounding the Armorican Massif. Our data confirm this hypothesis as no thermal event above $60^{\circ} \mathrm{C}$ is recorded by the samples after $175 \mathrm{Ma}$, suggesting that the burial depth of the sediments was lower than $2-3 \mathrm{~km}$ if we consider a geothermal gradient of $20^{\circ} \mathrm{C} / \mathrm{km}$ in the sediment cover. The Lower-Mesozoic exhumation event recorded by apatite fission tracks analyses on the Guérande granite samples does not seem responsible for a uranium remobilization in the area.

\section{Conclusion}

The multi-approach study on the leucogranite and uranium deposits from the Guérande district lead us to the following conclusions:

(1) The trace element geochemistry and airborne radiometric data on the Guérande leucogranite show anomalously low uranium content in the highly evolved facies from the apical zone. These low $U$ contents are likely a consequence of uranium leaching at the apex of the intrusion during hydrothermal alteration at depth, although we cannot exclude that some of the uranium was leached out during sub-surface weathering. Previous uranium 
enrichment at the apical zone was due to a fractional crystallization process and an interaction with late magmatic fluids.

(2) The ICP-MS and radiometric analyses carried out on the Guérande leucogranite show low Th/U values $(<2)$ which are in favor of the crystallization of magmatic uranium oxide.

(3) The oxygen isotope study performed on the Guérande leucogranite shows an isotopic disequilibrium between feldspar and quartz in the deformed samples from the roof of the intrusion. The low $\delta^{18} \mathrm{O}$ of the feldspar reflects a sub-solidus hydrothermal alteration by meteoric fluids whereas the quartz retained its magmatic signature. Solid-state extensional deformation likely facilitated the infiltration of surface-derived fluids at depth. These oxidizing fluids were able to leach uranium from the deformed facies sufficiently evolved to contain crystallized magmatic uranium oxides.

(4) The mass balance calculation suggests that the deformed facies from the apical zone could have liberated a sufficient amount of uranium to form the Pen Ar Ran deposit (i.e. $600 \mathrm{t} \mathrm{UO}_{2}$ mined).

(5) The fluid inclusion analyses on a quartz comb from a uranium oxide-bearing vein of the Pen Ar Ran deposit revealed a low salinity mineralizing fluid consistent with the contribution of meteoric waters. The elevated estimated fluid trapping temperatures $\left(250\right.$ to $\left.350^{\circ} \mathrm{C}\right)$ reflect an abnormal heat flux, likely related to the regional extensional regime that prevailed at the time of their circulation and possibly to magmatic activity at depth, in the near environment of the deposit.

(6) The REE patterns obtained on the uranium oxides from the Pen Ar Ran deposit are mostly comparable with the patterns of other vein-type deposits from the French Hercynian belt and are not consistent with the metavolcanic source previously proposed for the uranium of the deposit.

(7) The geochemistry and $\mathrm{U}-\mathrm{Pb}$ dating on the uranium oxides from the Pen Ar Ran and MétairieNeuve deposits revealed three mineralizing events. The first event, dated at $296.6 \pm 2.6 \mathrm{Ma}$, 
is sub-contemporaneous with hydrothermal circulations and a late magmatic event in the Guérande leucogranite at ca. $303 \mathrm{Ma}$. The two following mineralizing events occurred at ca. 285 and $275 \mathrm{Ma}$. The apatite fission track analysis indicates that the Guérande leucogranite was still at depth, above $120^{\circ} \mathrm{C}$, when these two mineralizing events occurred.

All these new data allow us to propose the Guérande leucogranite as the main source for the uranium of the Pen Ar Ran and Métairie-Neuve deposits. We suggest that the uranium was leached out from the deformed facies of the apical zone by oxidizing meteoric fluids at depth. The U leached by these fluids could have then precipitated in the reducing environment constituted by the surrounding black shales (Pen Ar Ran) or graphitic quartzite (Métairie-Neuve) to form the uranium deposits. As the different mineralizing events can be separated by ca. $25 \mathrm{Ma}$, percolation of oxidizing surface-derived fluids could have occurred, probably by pulses, during a long period of time when the Guérande leucogranite was still at depth. The model proposed in this study to constrain the $U$ mineralizing process in deposits spatially associated with the Guérande leucogranite could possibly be applied to other $U$ deposits related to peraluminous granites in the Hercynian Belt. Indeed, the ages of the $\mathrm{U}$ mineralizing events in the Guérande region (300-275 Ma) are in the same range as most $U$ deposits in the European Hercynian Belt (e.g. French Massif Central and Erzgebirge). In Europe, this period could be characterized by regional scale infiltration of oxidizing meteoric fluids down to upper-middle crustal levels that were then able to mobilize uranium from the peraluminous granites. To verify this hypothesis, the present study must be applied to other $\mathrm{U}$ fertile intrusions, such as the Pontivy granite in the case of the Armorican Massif for example.

\section{Acknowledgments}

This work was supported by the 2012-2013 NEED-CNRS (AREVA-CEA) and 2014-CESSUR-INSU (CNRS) grants attributed to Marc Poujol. We are grateful to AREVA (in particular to D. Virlogeux and J-M. Vergeau) for providing uranium oxides samples and for fruitful discussions. Many thanks to $\mathrm{S}$. Matthieu, L. Salsi, O. Rouer from the SCMEM (GeoRessources - Nancy), M.C. Caumon 
(GeoRessources - Nancy) and B. Putlitz (UNIL - Lausanne) for technical support during the SEM,

EPMA, Raman and oxygen isotope analyses. We thank G. Martelet (BRGM) for providing the airborne radiometric data. The manuscript benefited from the comments of two anonymous reviewers and the associated editor H.G. Dill. S. Mullin, a professional translator, proof-read the manuscript.

\section{Bibliography}

Audren, C., Jegouzo, P., Barbaroux, L., Bouysse, P., 1975. La Roche-Bernard, 449. Bureau de Recherches Géologiques et Minières.

Ballèvre, M., Bosse, V., Ducassou, C., Pitra, P., 2009. Palaeozoic history of the Armorican Massif: Models for the tectonic evolution of the suture zones. Comptes Rendus Geosci. 341, 174201. doi:10.1016/j.crte.2008.11.009

Ballèvre, M., Fourcade, S., Capdevila, R., Peucat, J.-J., Cocherie, A., Fanning, C.M., 2012. Geochronology and geochemistry of Ordovician felsic volcanism in the Southern Armorican Massif (Variscan belt, France): Implications for the breakup of Gondwana. Gondwana Res. 21, 1019-1036. doi:10.1016/j.gr.2011.07.030

Ballouard, C., Boulvais, P., Poujol, M., Gapais, D., Yamato, P., Tartèse, R., Cuney, M., 2015.Tectonic record, magmatic history and hydrothermal alteration in the Hercynian Guérande leucogranite, Armorican Massif, France. Lithos 220-223, 1-22. doi:10.1016/j.lithos.2015.01.027

Barsukov, V.L., Sokolova, N.T., Ivanitskii, O.M., 2006. Metals, arsenic, and sulfur in the Aue and Eibenstock granites, Erzgebirge. Geochem. Int. 44, 896-911. doi:10.1134/S0016702906090059

Bernard-Griffiths, J., Peucat, J.J., Sheppard, S., Vidal, P., 1985. Petrogenesis of Hercynian leucogranites from the southern Armorican Massif: contribution of REE and isotopic (Sr, Nd, $\mathrm{Pb}$ and $\mathrm{O})$ geochemical data to the study of source rock characteristics and ages. Earth Planet. Sci. Lett. 74, 235-250. doi:10.1016/0012-821X(85)90024-X

Berthé, D., Choukroune, P., Jegouzo, P., 1979. Orthogneiss, mylonite and non coaxial deformation of granites: the example of the South Armorican Shear Zone. J. Struct. Geol. 1, 31-42. doi:10.1016/0191-8141(79)90019-1

Bessin, P., Guillocheau, F., Robin, C., Schroëtter, J.-M., Bauer, H., 2015. Planation surfaces of the Armorican Massif (western France): Denudation chronology of a Mesozoic land surface twice exhumed in response to relative crustal movements between Iberia and Eurasia. Geomorphology, Patterns and rates of Cenozoic landscape change in orogenic and postorogenic settings 233, 75-91. doi:10.1016/j.geomorph.2014.09.026

Bodnar, R.J., 1993. Revised equation and table for determining the freezing point depression of $\mathrm{H}_{2} \mathrm{O}-$ Nacl solutions.Geochim.Cosmochim. Acta 57, 683-684. doi:10.1016/0016-7037(93)90378-A

Bonhoure, J., Kister, P., Cuney, M., Deloule, E., 2007.Methodology for Rare Earth Element Determinations of Uranium Oxides by lon Microprobe.Geostand. Geoanalytical Res. 31, 209225. doi:10.1111/j.1751-908X.2007.00865.x

Bonijoly, D., Perrin, J., Truffert, C., Asfirane, F., 1999.Couverture géophysique aéroportée du Massif armoricain, magnétisme et radiométrie spectrale. Rapport B.R.G.M. R40471. 75 p.

Bosse, V., Ballevre, M., Vidal, O., 2002. Ductile Thrusting Recorded by the Garnet Isograd from Blueschist-Facies Metapelites of the Ile de Groix, Armorican Massif, France. J. Petrol. 43, 485-510. doi:10.1093/petrology/43.3.485

Bosse, V., Féraud, G., Ballèvre, M., Peucat, J.-J., Corsini, M., 2005. Rb-Sr and ${ }^{40} \mathrm{Ar} /{ }^{39} \mathrm{Ar}$ ages in blueschists from the lle de Groix (Armorican Massif, France): Implications for closure 
mechanisms in isotopic systems. Chem. Geol. 220, 21-45.

doi:10.1016/j.chemgeo.2005.02.019

Bouchez, J.L., Guillet, P., Chevalier, F., 1981. Structures d'ecoulement liées à la mise en place du granite de Guérande (Loire-Atlantique, France). Bull. Soc. Geol. Fr. S7-XXIII, 387-399. doi:10.2113/gssgfbull.S7-XXIII.4.387

Bossière, G., 1988. Evolutions chimico-minéralogiques du grenat et de la muscovite au voisinage de l'isograde biotite-staurotide dans un métamorphisme prograde de type barrovien: un exemple en Vendée littorale (Massif Armoricain). Comptes Rendus de l'Académie des Sciences, Paris, série II 306, 135-140.

Breiter, K., 2012. Nearly contemporaneous evolution of the A- and S-type fractionated granites in the Krušné hory/Erzgebirge Mts., Central Europe. Lithos 151, 105-121. doi:10.1016/j.lithos.2011.09.022

Brown, M., Dallmeyer, R.D., 1996. Rapid Variscan exhumation and the role of magma in core complex formation: southern Brittany metamorphic belt, France. J. Metamorph. Geol. 14, 361-379. doi:10.1111/j.1525-1314.1996.00361.x

Burg, J.P., Van Den Driessche, J., Brun, J.P., 1994. Syn- to post thickening extension in the Variscan Belt of Western Europe: modes and structural consequences. Géologie de la France 3, 33-51.

Cagnard, F., Gapais, D., Brun, J.P., Gumiaux, C., Van den Driessche, J., 2004. Late pervasive crustalscale extension in the south Armorican Hercynian belt (Vendée, France). J. Struct. Geol. 26, 435-449. doi:10.1016/j.jsg.2003.08.006

Carl, C., Dill, H.G., Kreuzer, H., Wendt, I., 1983. U-Pb dating of ores in NE Bavaria. Terra Cognita 3, 195-196.

Cathelineau, M., 1981. Les Gisements Uraniferes de la Presqu'ile Guerandaise (Sud Bretagne); Approche Structurale et Metallogenique. Miner. Deposita 16, 227-240. doi:10.1007/BF00202737

Cathelineau, M., 1982. Les gisements d'uranium liés spatialement aux leucogranites sud-armoricains et à leur encaissant métamorphique : relations et interactions entre les minéralisations et divers contextes géologiques et structuraux. Université de Nancy. 375 p. (Sciences de la Terre, Mémoires, 42).

Cathelineau, M., Boiron, M.C., Holliger, P., Poty, B., 1990. Metallogenesis of the French part of the Variscan orogen. Part II: Time-space relationships between $\mathrm{U}, \mathrm{Au}$ and $\mathrm{Sn}-\mathrm{W}$ ore deposition and geodynamic events - mineralogical and U-Pb data. Tectonophysics 177, 59-79. doi:10.1016/0040-1951(90)90274-C

Caumon, M.-C., Dubessy, J., Robert, P., Tarantola, A., 2013. Fused-silica capillary capsules (FSCCs) as reference synthetic aqueous fluid inclusions to determine chlorinity by Raman spectroscopy. Eur. J. Mineral. 25, 755-763. doi:10.1127/0935-1221/2013/0025-2280

Caumon, M.-C., Tarantola, A., Mosser-Ruck, R., 2015. Raman spectra of water in fluid inclusions: I. Effect of host mineral birefringence on salinity measurement. J. Raman Spectrosc. doi:10.1002/jrs.4708

Chauris, L., 1977. Les associations paragenetiques dans la metallogenie varisque du massif armoricain. Miner. Deposita 12, 353-371. doi:10.1007/BF00206172

Chen, Y., Clark, A.H., Farrar, E., Wasteneys, H.A.H.P., Hodgson, M.J., Bromley, A.V., 1993. Diachronous and independent histories of plutonism and mineralization in the Cornubian Batholith, southwest England. J. Geol. Soc. 150, 1183-1191. doi:10.1144/gsjgs.150.6.1183

Cottaz, Y., Barthes, V., Berne, S., Crochon, P., Lericolais, G., Robach, F., 1989.Acoustic, magnetic and seismic investigation of the sea floor off the uraniferous district of Piriac, France. Mar. Geol. 86, 201-220. doi:10.1016/0025-3227(89)90049-2

Couzinié, S., Moyen, J.-F., Villaros, A., Paquette, J.-L., Scarrow, J.H., Marignac, C., 2014. Temporal relationships between $\mathrm{Mg}-\mathrm{K}$ mafic magmatism and catastrophic melting of the Variscan crust in the southern part of Velay Complex (Massif Central, France). J. Geosci. 69-86.

doi:10.3190/jgeosci.155 
Cuney, M., 2014.Felsic magmatism and uranium deposits. Bull. Soc. Geol. Fr. 185, 75-92. doi:10.2113/gssgfbull.185.2.75

Cuney, M., Friedrich, M., Blumenfeld, P., Bourguignon, A., Boiron, M.C., Vigneresse, J.L., Poty, B., 1990. Metallogenesis in the French part of the Variscan orogen. Part I: U preconcentrations in pre-Variscan and Variscan formations - a comparison with $\mathrm{Sn}, \mathrm{W}$ and $\mathrm{Au}$. Tectonophysics 177, 39-57. doi:10.1016/0040-1951(90)90273-B

Derome, D., Cathelineau, M., Cuney, M., Fabre, C., Lhomme, T., Banks, D.A., 2005. Mixing of Sodic and Calcic Brines and Uranium Deposition at McArthur River, Saskatchewan, Canada: A Raman and Laser-Induced Breakdown Spectroscopic Study of Fluid Inclusions. Econ. Geol. 100, 1529-1545. doi:10.2113/gsecongeo.100.8.1529

Dill, H.G., 1983. Vein-and metasedimentary-hosted carbonaceous matter and phosphorus from NE Bavaria (FR Germany) and their implication on syngenetic and epigenetic uranium concentration. Neues Jb Mineral Abh 148, 1-21.

Dill, H.G., 2015. The Hagendorf-Pleystein Province: The center of pegmatites in an ensialic orogen. Modern Approaches in Solid Earth Sciences, Springer, Dortrecht, Heidelberg, London, New York, $475 \mathrm{pp}$

Dolníček, Z., René, M., Hermannová, S., Prochaska, W., 2013. Origin of the Okrouhlá Radouň episyenite-hosted uranium deposit, Bohemian Massif, Czech Republic: fluid inclusion and stable isotope constraints. Miner. Deposita 49, 409-425. doi:10.1007/s00126-013-0500-5

Dubessy, J., Ramboz, C., Nguyen Trung, C., Cathelineau, M., Charoy, B., Cuney, M.; Leroy, J.; Poty, B.; Weisbrod, A., 1987.Physical and chemical control $\left(\mathrm{pO}_{2}, \mathrm{~T}, \mathrm{pH}\right)$ of the opposite behaviour of $U$ and $\mathrm{Sn}-\mathrm{W}$ as exemplified by hydrothermal deposits in France and Great Britain, and solubility data. Bull. de Minéralogie, 262-281.

Dubessy, J., Pagel, M., Beny, J.-M., Christensen, H., Hickel, B., Kosztolanyi, C., Poty, B., 1988. Radiolysis evidenced by $\mathrm{H}_{2}-\mathrm{O}_{2}$ and $\mathrm{H}_{2}$-bearing fluid inclusions in three uranium deposits. Geochim.Cosmochim. Acta 52, 1155-1167. doi:10.1016/0016-7037(88)90269-4

Dubinina, E.O., Nosova, A.A., Avdeenko, A.S., Aranovich, L.Y., 2010. Isotopic (Sr, Nd, O) systematics of the high $\mathrm{Sr}$-Ba Late Miocene granitoid intrusions from the Caucasian Mineral Waters region. Petrology 18, 211-238. doi:10.1134/S086959111003001X

Dunkl, l., 2002. Trackkey: a Windows program for calculation and graphical presentation of fission track data. Computers and Geosciences 28, 3-12.

Eglinger, A., André-Mayer, A.-S., Vanderhaeghe, O., Mercadier, J., Cuney, M., Decrée, S., Feybesse, J.L., Milesi, J.-P., 2013. Geochemical signatures of uranium oxides in the Lufilian belt: From unconformity-related to syn-metamorphic uranium deposits during the Pan-African orogenic cycle. Ore Geol. Rev. 54, 197-213. doi:10.1016/j.oregeorev.2013.04.003

Eikenberg, J., 1988. Vergleichende Datierungen von Uranmineralen mit den U-Xe, U-Kr und U-PbSystemen sowie Untersuchungen der Produktion von Ne und Ar durch Kemprozesse. Ph.D. Thesis ETH Zürich. (Comparative dating of $U$ minerals using the U-Xe, U-Kr and U-Pb systems and supplementary investigations concerning the production of $\mathrm{Ne}$ and $\mathrm{Ar}$ by nuclear processes).

Faure, M., 1995. Late orogenic carboniferous extensions in the Variscan French Massif Central. Tectonics 14, 132-153. doi:10.1029/94TC02021

Fernández-Suárez, J., Dunning, G.R., Jenner, G.A., Gutiérrez-Alonso, G., 2000. Variscan collisional magmatism and deformation in NW Iberia: constraints from $\mathrm{U}-\mathrm{Pb}$ geochronology of granitoids. J. Geol. Soc. 157, 565-576. doi:10.1144/jgs.157.3.565

Finger, F., Roberts, M.P., Haunschmid, B., Schermaier, A., Steyrer, H.P., 1997. Variscan granitoids of central Europe: their typology, potential sources and tectonothermal relations. Mineral. Petrol. 61, 67-96. doi:10.1007/BF01172478

Friedrich, M., Cuney, M., Poty, B., 1987.Uranium geochemistry in peraluminous leucogranites. Uranium, 3, 353-385.

Fryer, B.J., Taylor, R.P., 1987. Rare-earth element distributions in uraninites: Implications for ore genesis. Chem. Geol. 63, 101-108. doi:10.1016/0009-2541(87)90077-5 
Galbraith, R.F., Laslett, G.M., 1993. Statistical models for mixed fission track ages. Nucl. Tracks Radiat. Meas. 21, 459-470. doi:10.1016/1359-0189(93)90185-C

Gallagher, K., 2012. Transdimensional inverse thermal history modeling for quantitative thermochronology. J. Geophys. Res. Solid Earth 117, B02408. doi:10.1029/2011JB008825

Gallagher, K., Charvin, K., Nielsen, S., Sambridge, M., Stephenson, J., 2009. Markov chain Monte Carlo (MCMC) sampling methods to determine optimal models, model resolution and model choice for Earth Science problems. Mar. Pet. Geol., Thematic Set on Basin Modeling Perspectives 26, 525-535. doi:10.1016/j.marpetgeo.2009.01.003

Gapais, D., Lagarde, J.L., Le Corre, C., Audren, C., Jegouzo P., Casas Sainz, A., Van Den Driessche, J., 1993. La zonede cisaillement de Quiberon: témoin d'extension de la chaine varisque en Bretagne méridionale auCarbonifère. Comptes Rendus de l'Académie des Sciences, Paris, série II, 316, 1123-1129.

Gapais, D., Brun, J.-P., Gumiaux, C., Cagnard, F., Ruffet, G., Le Carlier de Veslud, C., 2015. Extensional tectonics in the Hercynian Armorican belt (France). An overview. Bull. Soc. Geol. Fr. 186, 117-129. doi:10.2113/gssgfbull.186.2-3.117

Green, P.F., 1985. Comparison of zeta calibration baselines for fission-track dating of apatite, zircon and sphene. Chem. Geol. Isot. Geosci. Sect. 58, 1-22. doi:10.1016/0168-9622(85)90023-5

Gregory, R.T., Criss, R.E., 1986. Isotopic exchange in open and closed systems. Rev. Mineral. Geochem. 16, 91-127.

Guillocheau, F., Robin, C., Allemand, P., Bourquin, S., Brault, N., Dromart, G., Friedenberg, R., Garcia, J.-P., Gaulier, J.-M., Gaumet, F., Grosdoy, B., Hanot, F., Strat, P.L., Mettraux, M., Nalpas, T., Prijac, C., Rigoltet, C., Serrano, O., Grandjean, G., 2000. Meso-Cenozoic geodynamic evolution of the Paris Basin: 3D stratigraphic constraints. Geodin. Acta 13, 189-245. doi:10.1080/09853111.2000.11105372

Gumiaux, C., Gapais, D., Brun, J.P., Chantraine, J., Ruffet, G., 2004. Tectonic history of the Hercynian Armorican Shear belt (Brittany, France). Geodin. Acta 17, 289-307. doi:10.3166/ga.17.289307

Gutiérrez-Alonso, G., Fernández-Suárez, J., Jeffries, T.E., Johnston, S.T., Pastor-Galán, D., Murphy, J.B., Franco, M.P., Gonzalo, J.C., 2011. Diachronous post-orogenic magmatism within a developing orocline in Iberia, European Variscides. Tectonics 30, TC5008. doi:10.1029/2010TC002845

Gysi, A.P., Williams-Jones, A.E., 2013. Hydrothermal mobilization of pegmatite-hosted REE and Zr at Strange Lake, Canada: A reaction path model. Geochim. Cosmochim. Acta 122, 324-352. doi:10.1016/j.gca.2013.08.031

Harrison, T.M., Célérier, J., Aikman, A.B., Hermann, J., Heizler, M.T., 2009. Diffusion of ${ }^{40} \mathrm{Ar}$ in muscovite. Geochim.Cosmochim. Acta 73, 1039-1051. doi:10.1016/j.gca.2008.09.038

Hofmann, B., Eikenberg, J., 1991. The Krunkelbach uranium deposit, Schwarzwald, Germany; correlation of radiometric ages (U-Pb, U-Xe-Kr, K-Ar, ${ }^{230} \mathrm{Th}^{234} \mathrm{U}$ ). Econ. Geol. 86, 1031-1049. doi:10.2113/gsecongeo.86.5.1031

International Atomic Energy Agency (IAEA). 2012. UDEPO - World Distribution of Uranium Deposits.

IRSN, 2004. Inventaire national des sites miniers d'uranium. Institut de Radioprotection et de Sureté Nucléaire.

Jolivet, J., Bienfait, G., Vigneresse, J.L., Cuney, M., 1989. Heat flow and heat production in Brittany (Western France). Tectonophysics 159, 61-72. doi:10.1016/0040-1951(89)90170-4

Jolivet, M., Dominguez, S., Charreau, J., Chen, Y., Li, Yongan, Wang, Qingchen, 2010. Mesozoic and Cenozoic tectonic history of the Central Chinese Tian Shan: reactivated tectonic structures and active deformation. Tectonics 29, 6. doi:10.1029/2010TC002712

Jones, K.A., Brown, M., 1990. High-temperature "clockwise"P-T paths and melting in the development of regional migmatites: an example from southern Brittany, France. J. Metamorph. Geol. 8, 551-578. doi:10.1111/j.1525-1314.1990.tb00486.x

Ketcham, R.A., Carter, A., Donelick, R.A., Barbarand, J., Hurford, A.J., 2007. Improved modeling of fission-track annealing in apatite. Am. Mineral. 92, 799-810. doi:10.2138/am.2007.2281 
Kříbek, B., Žák, K., Dobeš, P., Leichmann, J., Pudilová, M., René, M., Scharm, B., Scharmová, M., Hájek, A., Holeczy, D., Hein, U.F., Lehmann, B., 2009. The Rožná uranium deposit (Bohemian Massif, Czech Republic): shear zone-hosted, late Variscan and post-Variscan hydrothermal mineralization. Miner. Deposita 44, 99-128. doi:10.1007/s00126-008-0188-0

Lach, P., Mercadier, J., Dubessy, J., Boiron, M.-C., Cuney, M., 2013. In Situ Quantitative Measurement of Rare Earth Elements in Uranium Oxides by Laser Ablation-Inductively Coupled PlasmaMass Spectrometry. Geostand. Geoanalytical Res. 37, 277-296. doi:10.1111/j.1751908X.2012.00161.x

Laurent, O., Couzinié, S., Vanderhaeghe, O., Zeh, A., Moyen, J.F., Villaros, A., Gardien, V., 2015. U-Pb dating of Variscan igneous rocks from the eastern French Massif Central: southward migration of coeval crust- and mantle- melting witnesses late-orogenic slab retreat. Variscan conference, Rennes.

Le Hébel, F., 2002. Déformation continentale et histoire des fluides au cours d'un cycle subduction, exhumation, extension. Exemple des porphyroïdes Sud-Armoricains. Thèse Université de Rennes 1, $218 \mathrm{p}$.

Le Hébel, F., Vidal, O., Kienast, J.-R., Gapais, D., 2002. Les Porphyroïdes de Bretagne méridionale: une unité de HP-BT dans la chaîne hercynienne. Comptes Rendus Geosci. 334, 205-211.

Le Hébel, F., Fourcade, S., Boiron, M.-C., Cathelineau, M., Capdevila, R., Gapais, D., 2007. Fluid history during deep burial and exhumation of oil-bearing volcanics, Hercynian Belt of southern Brittany, France. Am. J. Sci. 307, 1096-1125. doi:10.2475/09.2007.03

Lemarchand, J., Boulvais, P., Gaboriau, M., Boiron, M.-C., Tartèse, R., Cokkinos, M., Bonnet, S., Jégouzo, P., 2012. Giant quartz vein formation and high-elevation meteoric fluid infiltration into the South Armorican Shear Zone: geological, fluid inclusion and stable isotope evidence. J. Geol. Soc. 169, 17-27. doi:10.1144/0016-76492010-186

Ludwig, K.R., 2012. Isoplot, A Geochronological Toolkit for Microsoft Excel. Berkeley Geochronology Center, Special Publication No. 5, p. 75.

Mayanovic, R.A., Anderson, A.J., Bassett, W.A., Chou, I.-M., 2015. Steric hindrance and the enhanced stability of light rare-earth elements in hydrothermal fluids. Am. Mineral. 94, 1487-1490. doi:10.2138/am.2009.3250

McDonough, W.F., Sun, S.S., 1995. The composition of the Earth. Chem. Geol., Chemical Evolution of the Mantle 120, 223-253. doi:10.1016/0009-2541(94)00140-4

McDowell, F.W., McIntosh, W.C., Farley, K.A., 2005. A precise ${ }^{40} \mathrm{Ar}-{ }^{39} \mathrm{Ar}$ reference age for the Durango apatite (U-Th)/He and fission-track dating standard. Chem. Geol. 214, 249-263. doi:10.1016/j.chemgeo.2004.10.002

Mercadier, J., Cuney, M., Cathelineau, M., Lacorde, M., 2010. U redox fronts and kaolinisation in basement-hosted unconformity-related $\mathrm{U}$ ores of the Athabasca Basin (Canada): late $U$ remobilisation by meteoric fluids. Miner. Deposita 46, 105-135. doi:10.1007/s00126-0100314-7

Mercadier, J., Cuney, M., Lach, P., Boiron, M.-C., Bonhoure, J., Richard, A., Leisen, M., Kister, P., 2011.Origin of uranium deposits revealed by their rare earth element signature. Terra Nova 23, 264-269. doi:10.1111/j.1365-3121.2011.01008.x

Ouddou, D., 1984. Le Massif de Guérande-Le Croisic (Loire-Atlantique): Caractérisation géochimique et minéralogique de l'évolution magmatique. Comportement de l'uranium. Thèse, INPLCREGU Nancy, 309p.

Peiffert, C., Nguyen-Trung, C., Cuney, M., 1996. Uranium in granitic magmas: Part 2. Experimental determination of uranium solubility and fluid-melt partition coefficients in the uranium oxide-haplogranite- $\mathrm{H}_{2} \mathrm{O}-\mathrm{NaX}(\mathrm{X}=\mathrm{Cl}, \mathrm{F})$ system at $770^{\circ} \mathrm{C}, 2$ kbar. Geochim.Cosmochim. Acta 60, 1515-1529. doi:10.1016/0016-7037(96)00039-7

Pérez Del Villar, L., Moro, C., 1991. Las mineralizaciones intragraníticas de Uranio en el batolito de Cabeza de Ar aya (provincia de Cáceres): El Saguazal, Brechas NNE y La Zafrilla. Studia Geologica Salmanticensia 27. 
Roger, F., Teyssier, C., Respaut, J.-P., Rey, P.F., Jolivet, M., Whitney, D.L., Paquette, J.-L., Brunel, M., 2015. Timing of formation and exhumation of the Montagne Noire double dome, French Massif Central. Tectonophysics 640-641, 53-69. doi:10.1016/j.tecto.2014.12.002

Schaltegger, U., 2000. U-Pb geochronology of the Southern Black Forest Batholith (Central Variscan Belt): timing of exhumation and granite emplacement. Int. J. Earth Sci. 88, 814-828. doi:10.1007/s005310050308

Stacey, J.S., Kramers, J.D., 1975. Approximation of terrestrial lead isotope evolution by a two-stage model.Earth Planet. Sci. Lett. 26, 207-221. doi:10.1016/0012-821X(75)90088-6

Sobel, E. R., and Seward, D., 2010. Influence of etching conditions on apatite fission track etch pit diameter, Chem. Geol. 271, 59-69, doi:10.1016/j. chemgeo.2009.12.012.

Tagami, T., 1987. Determination of zeta calibration constant for fission track dating. Int. J. Radiat. Appl. Instrum. Part Nucl. Tracks Radiat. Meas. 13, 127-130. doi:10.1016/13590189(87)90023-9

Tartèse, R., Boulvais, P., 2010. Differentiation of peraluminous leucogranites "en route" to the surface. Lithos 114, 353-368. doi:10.1016/j.lithos.2009.09.011

Tartèse, R., Poujol, M., Ruffet, G., Boulvais, P., Yamato, P., Košler, J., 2011a.New U-Pb zircon and ${ }^{40} \mathrm{Ar} /{ }^{39} \mathrm{Ar}$ muscovite age constraints on the emplacement of the Lizio syn-tectonic granite (Armorican Massif, France). Comptes Rendus Geosci. 343, 443-453. doi:10.1016/j.crte.2011.07.005

Tartèse, R., Ruffet, G., Poujol, M., Boulvais, P., Ireland, T.R., 2011b. Simultaneous resetting of the muscovite K-Ar and monazite U-Pb geochronometers: a story of fluids. Terra Nova 23, 390398. doi:10.1111/j.1365-3121.2011.01024.x

Tartèse, R., Boulvais, P., Poujol, M., Chevalier, T., Paquette, J.-L., Ireland, T.R., Deloule, E., 2012. Mylonites of the South Armorican Shear Zone: Insights for crustal-scale fluid flow and waterrock interaction processes. J. Geodyn. 56-57, 86-107. doi:10.1016/j.jog.2011.05.003

Tartèse, R., Boulvais, P., Poujol, M., Gloaguen, E., Cuney, M., 2013. Uranium Mobilization from the Variscan Questembert Syntectonic Granite During Fluid-Rock Interaction at Depth. Econ. Geol. 108, 379-386. doi:10.2113/econgeo.108.2.379

Triboulet, C., Audren, C., 1988. Controls on P-T-t deformation path from amphibole zonation during progressive metamorphism of basic rocks (estuary of the River Vilaine, South Brittany, France). J. Metamorph. Geol. 6, 117-133. doi:10.1111/j.1525-1314.1988.tb00412.x

Turpin, L., Leroy, J.L., Sheppard, S.M.F., 1990. Isotopic systematics (O, H, C, Sr, Nd) of superimposed barren and U-bearing hydrothermal systems in a Hercynian granite, Massif Central, France. Chem. Geol. 88, 85-98. doi:10.1016/0009-2541(90)90105-G

Turrillot, P., Augier, R., Faure, M., 2009.The top-to-the-southeast Sarzeau shear zone and its place in the late-orogenic extensional tectonics of southern Armorica. Bull. Soc. Geol. Fr. 180, 247261. doi:10.2113/gssgfbull.180.3.247

Valley, J.W., 2003.Oxygen isotopes in zircon, in Hanchar, J.M. \& Hoskin, P.W.O. (eds.), Zircon. Reviews in Mineralogy and Geochemistry 53, 343-385.

Valois, J., 1975. Les formations métamorphiques de Pénaran (presqu'île de Guérande, Loire Atlantique) et leur minéralisation uranifère (Thèse 3e cycle, Nancy, 136 pp.).

Van Den Driessche, J., Brun, J.P., 1989. Un modèle cinématique de l'extension paléozoïque dans le Sud du Massif central. C. R. Acad. Sci. Paris, Ser II 309, 1607-1613.

Van Den Driessche, J., Brun, J.-P., 1992. Tectonic evolution of the Montagne Noire (french Massif Central): a model of extensional gneiss dome. Geodin. Acta 5, 85-97. doi:10.1080/09853111.1992.11105221

Velichkin, V.I., Vlasov, B.P., 2011. Domal structures and hydrothermal uranium deposits of the Erzgebirge, Saxony, Germany. Geol. Ore Depos. 53, 74-83. doi:10.1134/S1075701511010053

Vigneresse, J., 1983. Enracinement des granites armoricains estimé d'après la gravimétrie. Bulletin de la societé Géologique et minéralogique de Bretagne C (15 (1)), 1-15. 
Vigneresse, J.L., Cuney, M., Jolivet, J., Bienfait, G., 1989. Selective heat-producing element enrichment in a crustal segment of the mid-European Variscan chain. Tectonophysics 159, 47-60. doi:10.1016/0040-1951(89)90169-8

Vigneresse, J.L., 1995. Crustal regime of deformation and ascent of granitic magma. Tectonophysics 249, 187-202. doi:10.1016/0040-1951(95)00005-8

Wendt, L, Lenz, H., Höhndorf, A., Bültemann, H., Bültemann, W.D., 1979. Das Alter der Pechblende der Lagerstätte Menzenschwand, Schwarzwald. Zeitschrift der deutschen Geologischen Gesellschaft 130, 619-626. (with an abstract in English).

Zheng, Y.F., 1993. Calculation of oxygen isotope fractionation in anhydrous silicate minerals.Geochim. Cosmochim. Acta 57, 1079-1091. 


\section{Table captions}

Table 1: Average spectral gamma ray radiometric data

Table 2: Chemical composition of the studied uranium oxides, measured by EPMA and LA-ICP-MS

bdl $=$ below detection limit, Alt Ur1 = product of alteration of Ur1. PAR = Pen Ar Ran. MN-granitic C.R. = Métairie-Neuve granitic country rock. MN-metased. C.R. = Métairie-Neuve metasedimentary country rock

Table 3: Microthermometric data and chemical composition of some representative fluid inclusions from a quartz comb associated with a uranium oxide vein of the Pen Ar Ran deposit.

Table 4: Oxygen isotope data

* Temperature calculation $\left({ }^{\circ} \mathrm{C}\right)$ following the calibration of Zheng (1993)

Table 5: Apatite fission track data

$\mathrm{Pd}$ is the denisty of the induced fission tracks $\left(\right.$ per $\mathrm{cm}^{2}$ ) that would be obtained in each sample if its $\mathrm{U}$ concentration was equal to the concentration of the CN5 glass dosimeter. Ps and Pi are the spontaneous and induced track densities per $\mathrm{cm}^{2}$ measured in the samples, respectively. The numbers in parentheses are the total number of tracks counted. $U$ is the calculated average $U$ concentration of apatite for each sample. $P\left(\chi^{2}\right)$ is is the probability in $\%$ of $\chi 2$ for $v$ degrees of freedom (where $v=$ number of crystals1). The age is the central age. Dpar is the measured mean diameter (in $\mu \mathrm{m}$ ) of the etched trace of the intersection of a fission track with the surface of the analyzed apatite crystal, measured parallelly to the $\mathrm{c}$ axis. 


\section{Figure Captions}

Figure 1: Structural map of the southern part of the Armorican Massif showing the localization of the uranium deposits and carboniferous peraluminous granites. Modified from Ballouard et al. (2015). SBSASZ: southern branch of the South Armorican Shear Zone. NBSASZ: northern branch of the South Armorican Shear Zone.

Figure 2: Geological and structural map of the Guérande granite modified after Ballouard et al. (2015). The localization of the studied samples and $U$ deposits and Sn showings, together with the alteration types, are also reported.

Figure 3: Simplified cross-section of the extensional graben ("Piriac graben") affecting the apical zone of the Guérande granite, with a projection of the Pen Ar Ran U deposit and Sn showing. The crosssection is localized on the map.

Figure 4: $U$ mineralization of the Pen Ar Ran deposit. (a) $U$ oxide-quartz bearing veins (Ur) intruding the metavolcanics. (b) The uranium oxide-quartz bearing veins (Ur) are blocked at the contact between the reducing black shales and crosscut the foliation (S) of the metavolcanics. (c) The mineralization filled $N 70^{\circ}$ tension gashes associated with the development of a $\mathrm{N} 110^{\circ}$ sub-vertical sinistral fault inside the metavolcanics. Yellow minerals $(b-c)$ correspond to hexavalent $U$ minerals formed quickly after the mine gallery opening, and revealing the distribution of the $U$ ores.

Figure 5: Back-scattered electron (BSE; a-c-d-e-f) and reflected light (b) images of the uranium oxide samples analyzed in this study. The dates associated with SIMS analyses correspond to the common $\mathrm{Pb}$-corrected punctual ${ }^{206} \mathrm{~Pb} /{ }^{238} \mathrm{U}$ ages (Ma). The numbers associated with LA-ICP-MS analyses (a) refer to the REE patterns presented in Fig. 6b. (a) Spherulitic uranium oxide from the Pen Ar Ran deposit (PAR-spherulitic). The spherulites (Ur1) are characterized by concentric zonation and the borders display a darker color than the cores. Alteration products of Ur1 (Alt Ur1) occur along microfractures (b-c) Pseudo-spherulitic uranium oxide from the Pen Ar Ran deposit (PAR-pseudospherulitic). In (b), the filling of the vein sample intruding the metavolcanics (Volc.) begins with a 500 $\mu \mathrm{m}$ thick quartz comb (Qtz) on which uranium oxides (Ur1) have grown. The central part of the vein and fractures are commonly filled with sulfide such as pyrite (Py), chalcopyrite (CPy) and are associated with a product of alteration of Ur1 (Alt Ur1). (d) Prismatic uranium oxide from the Pen Ar Ran deposit (PAR-prismatic). (e-f) Uranium oxide from the Métairie-Neuve deposit. In (e), the uranium oxides occur within a granitic country rock (MN-granitic C.R.) and the first generation of uranium oxide (Ur1) is crosscut by fractures associated with the alteration of Ur1 (Alt Ur1), and the crystallization of galena and U-Ca-K phosphate (U-Ca-K- $\left.\mathrm{PO}_{4}\right)$. In (f), Uranium oxides occur within the metasedimentary country rock in enclaves in the Guérande granite ( $\mathrm{MN}$-metased.C.R.). 
Figure 6: (a) PbO vs. $\mathrm{CaO}$ diagram displaying the chemical composition of the uranium oxide samples analyzed in this study. (b-c-d) Chondrite-normalized REE patterns for uranium oxides from the Pen $\mathrm{Ar}$ Ran (PAR) and Métairie-Neuve (MN) deposits. The chondrite REE abundances used for normalization are from McDonough and Sun (1995).

Figure 7: Photomicrographs of some fluid inclusions observed in the quartz comb associated to a uranium oxide vein from the Pen Ar Ran deposit showing a variable degree of volatile filling. Notably, some fluid inclusions are oriented in the direction of growth of the host quartz crystal (a), and some are associated with mineral inclusions such as muscovite (d). The reference numbers of the fluid inclusions are the same as in Table 3.

Figure 8: (a-b) Histograms reporting the (a) salinity and (b) homogenization temperature $\left(T_{h}\right)$ of the fluid inclusions of the quartz comb associated with a uranium oxide vein from the Pen Ar Ran deposit. (c-d) Diagram reporting the homogenization temperature $\left(T_{h}\right)$ of fluid inclusions as a function of the (c) salinity and (d) degree of volatile filling. (b-c-d) Fluid inclusions homogenizing in the liquid phase (Liquid) are differentiated from those homogenizing in the vapor phase (Vapor).

Figure 9: (a-c-e) Wetherill concordia diagrams and (b-d-f) Tera Wasserburg diagrams displaying the analyses performed on the uranium oxides from the Pen $\mathrm{Ar}$ Ran and Métairie-Neuve deposits. The analyses reported in the Wetherill concordia diagrams are corrected from common $\mathrm{Pb}$ whereas the analyses reported on the Tera Wasserburg diagrams are not. Dashed ellipses correspond to analyses not used for date calculations. In all the diagrams, error ellipses are plotted at $1 \sigma$.

Figure 10: (a) Airborne radiometric map of $U$ in the Guérande granite area. The contour of the granite is shown in white. Radiometric data were obtained during an airborne survey of the Armorican Massif (Bonijoly et al., 1999). (b) U vs. Th diagram displaying the ICP-MS analyses of the Guérande granite (Ballouard et al., 2015) and of the metavolcanics of the Vendée porphyroid formation (Piriac graben and other areas of the South Armorican Massif: Belle-Ile en Mer and Vendée; Le Hébel, 2002) and spectral gamma ray radiometric data obtained on the Guérande granite and the metamorphic formations of the Piriac graben (metavolcanics and black shales of the Vendée porphyroid formation).

Figure 11: (a) Minerals (quartz and feldspar) vs. whole-rock $\delta^{18} O$ values for the Guérande granite samples. $\Delta^{18} \mathrm{O}_{(\mathrm{Qtz}-\mathrm{Fds})}$ of two representative samples are indicated. (b) Evolution of the $\delta^{18} \mathrm{O}$ values of whole-rock, quartz and feldspar of the samples as a function of the latitude. 
Figure 12: Apatite fission track (AFT) thermal modeling of the Guérande granite samples using the QTQt software (Gallagher et al., 2009) (a) Time-temperature history of the Guérande granite using fission track data of the GUE-3, GUE-4 and GUE-5 samples. The horizontal lines represent the apatite partial annealing zone. The model is well constrained only in this temperature interval. The gray area represents the $95 \%$ credible interval for the thermal history. The dashed line represents the expected weighted mean thermal history. (b-c-d) Apatite fission track lengths histogram of the Guérande granite samples. The histograms represent the measured data while the dashed lines represent the calculated data. N: number of track lengths measured.

Figure 13: Evolution of the $U$ whole-rock content of the Guérande granite samples as a function of geochemical tracers sensitive to magmatic differentiation and interaction with orthomagmatic fluids. Data from Ballouard et al. (2015).

Figure 14: Chronological sequence of the different events that occurred in the Guérande district between 310 and $270 \mathrm{Ma}$.

Figure 15: Drawing representing the uranium behavior evolution in the Guérande granite from ca. 310 to ca. $300 \mathrm{Ma}$. (a) At ca. 310Ma, the Guérande leucogranite emplaces and differentiates in an extensional deformation zone. The most evolved U-rich magmas migrate toward the apical zone of the intrusion. $U$ enrichment at the apical zone is enhanced by the interaction with orthomagmatic fluids that trigger the crystallization of "magmatic" uranium oxides. (b) At ca. $300 \mathrm{Ma}$, the regional deformation is still active. Oxidizing fluids derived from the surface circulate in the deformed facies of the apical zone of the Guérande leucogranite and become enriched in $U$ due to leaching of magmatic uranium oxides. The heat provided by a late magmatic event, as expressed by the emplacement of late leucogranite dykes, likely contributes to maintain the convective fluid circulations. U-rich fluids migrate toward the faults and precipitate $U$ at the contact with reducing environments, such as the black shales. Such a hydrothermal system was likely active until ca. 275 Ma.

Figure 16: Chronological sequence comparing the ages of $U$ mineralization with the period of peraluminous leucogranitic magmatism in the west European Hercynian belt. The period of leucogranites emplacement is from Fernández-Suárez et al. (2000), Gutiérrez-Alonso et al. (2011) for the Iberian Peninsula, Ballouard et al. (2015) and reference therein for the Armorican Massif, Couzinié et al. (2014), Laurent et al. (2015), Roger et al. (2015) for the French Massif Central, Schaltegger (2000) for the Black Forest, Finger et al. (1997), Breiter et al. (2012) for the Bohemian Massif. The ages of U mineralization are from (a) this study, (b) Cathelineau et al. (1990), (c) Hofmann and Eikenberg (1991), (d) Eikenberg (1988) (e) Wendt et al. (1979), (f) Dill (2015) and reference 
therein (g), Kríbek et al. (2008), (h) Velichkin and Vlasov (2011) and reference therein, (i) Pérez Del Villar and Moro (1991). 


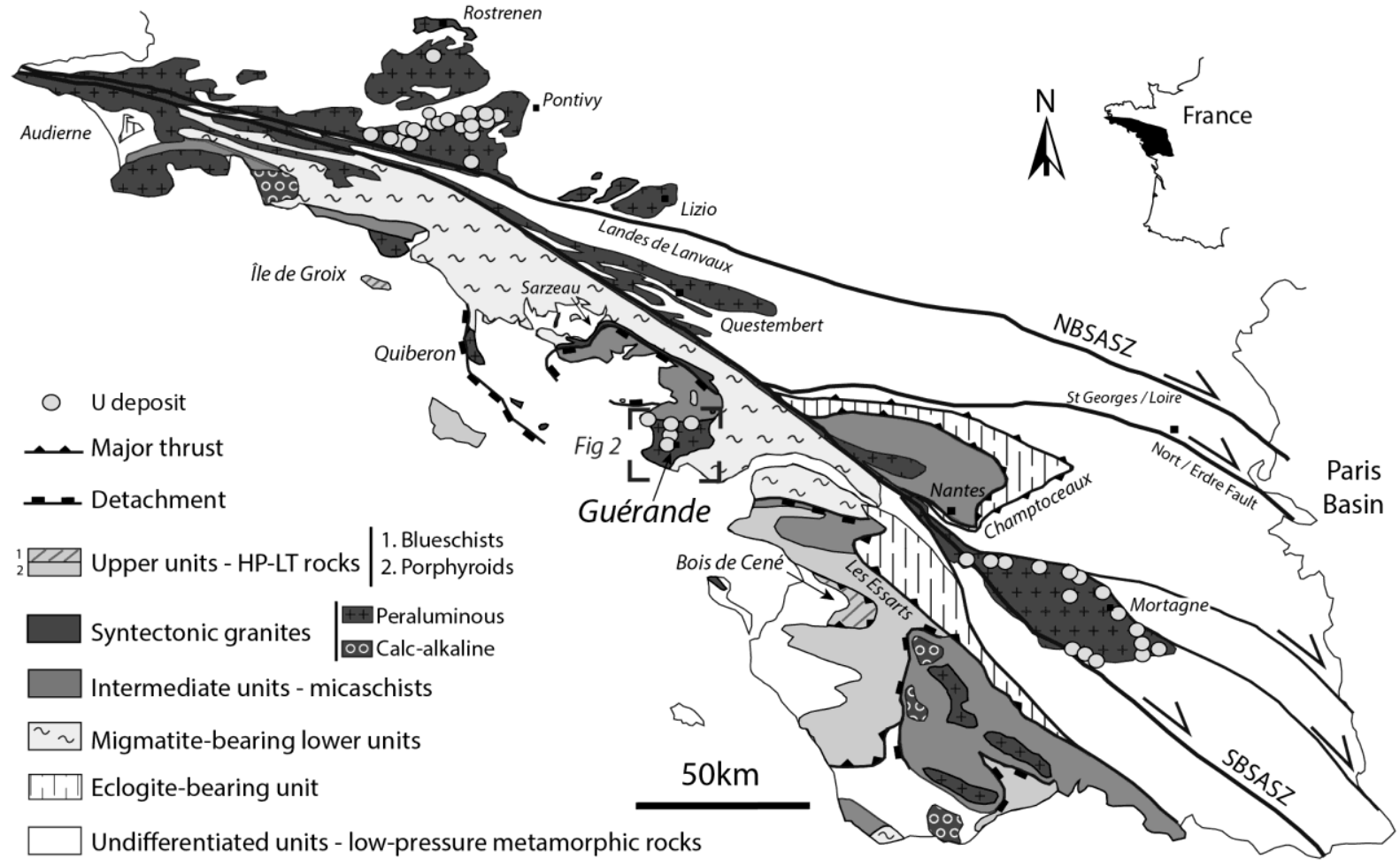

Fig. 1 


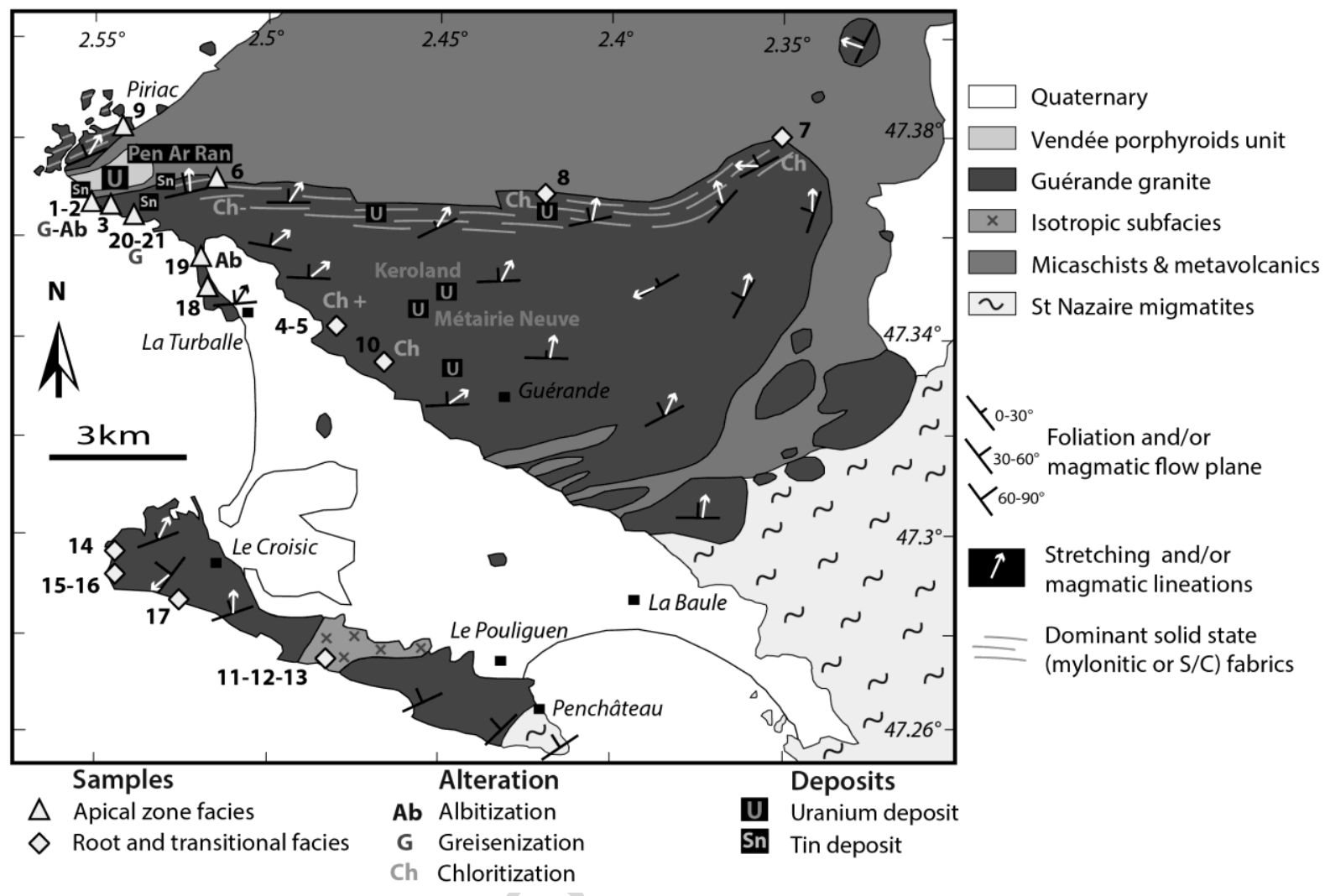

Fig. 2 


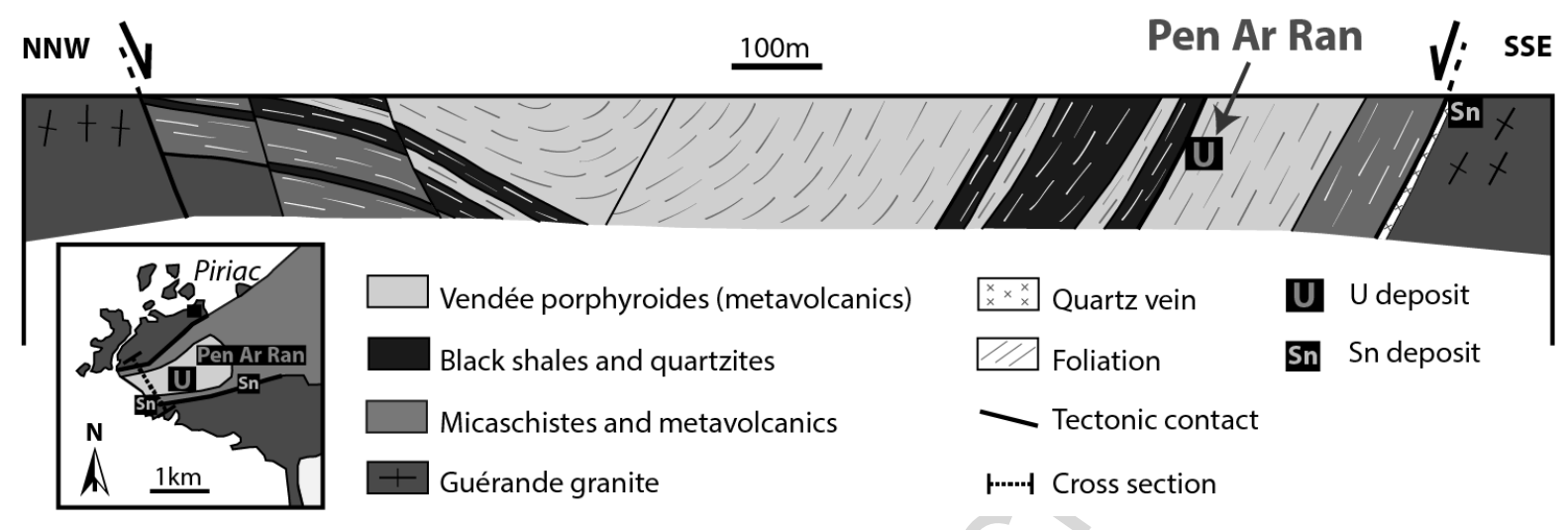

Fig. 3 

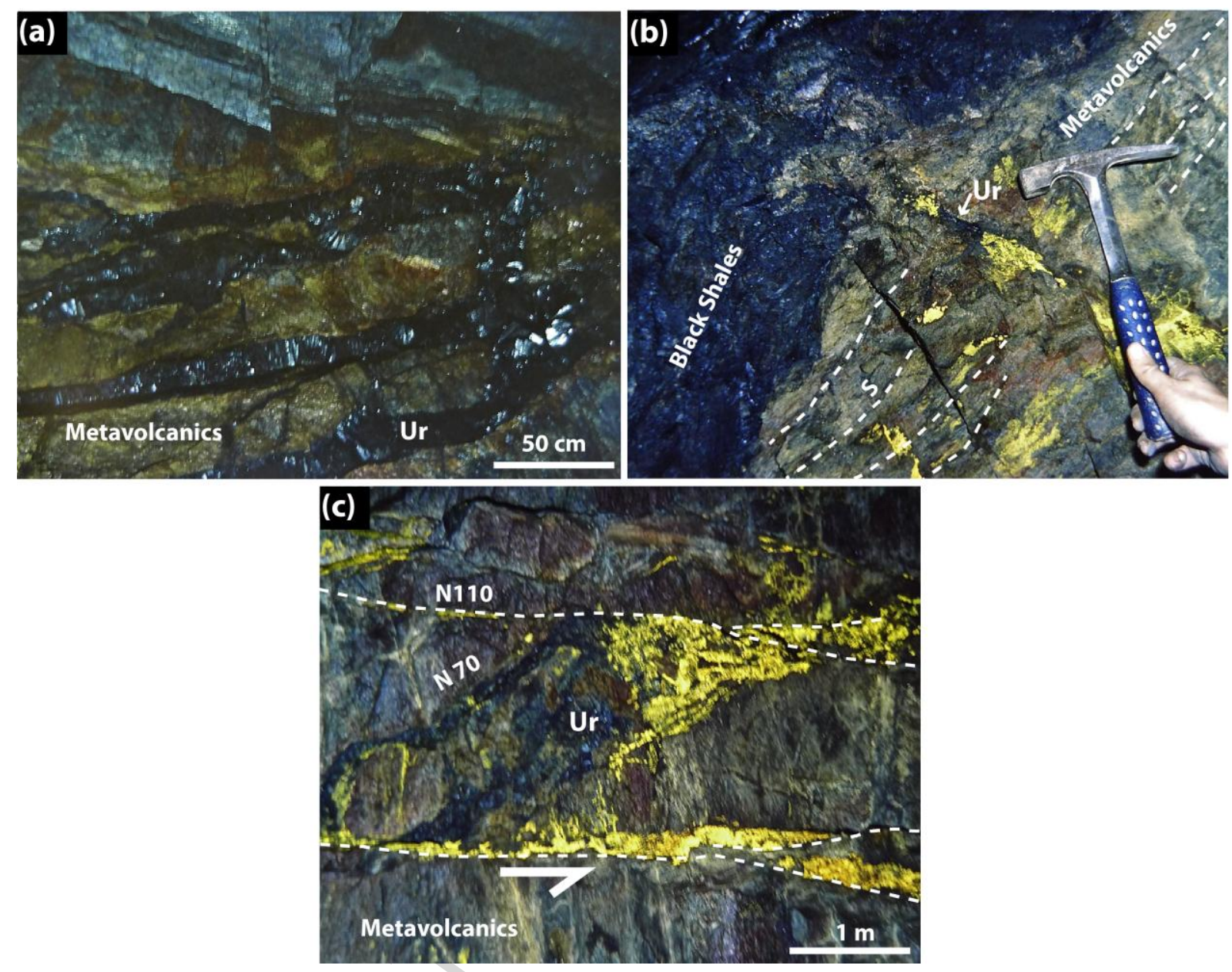

Fig. 4 

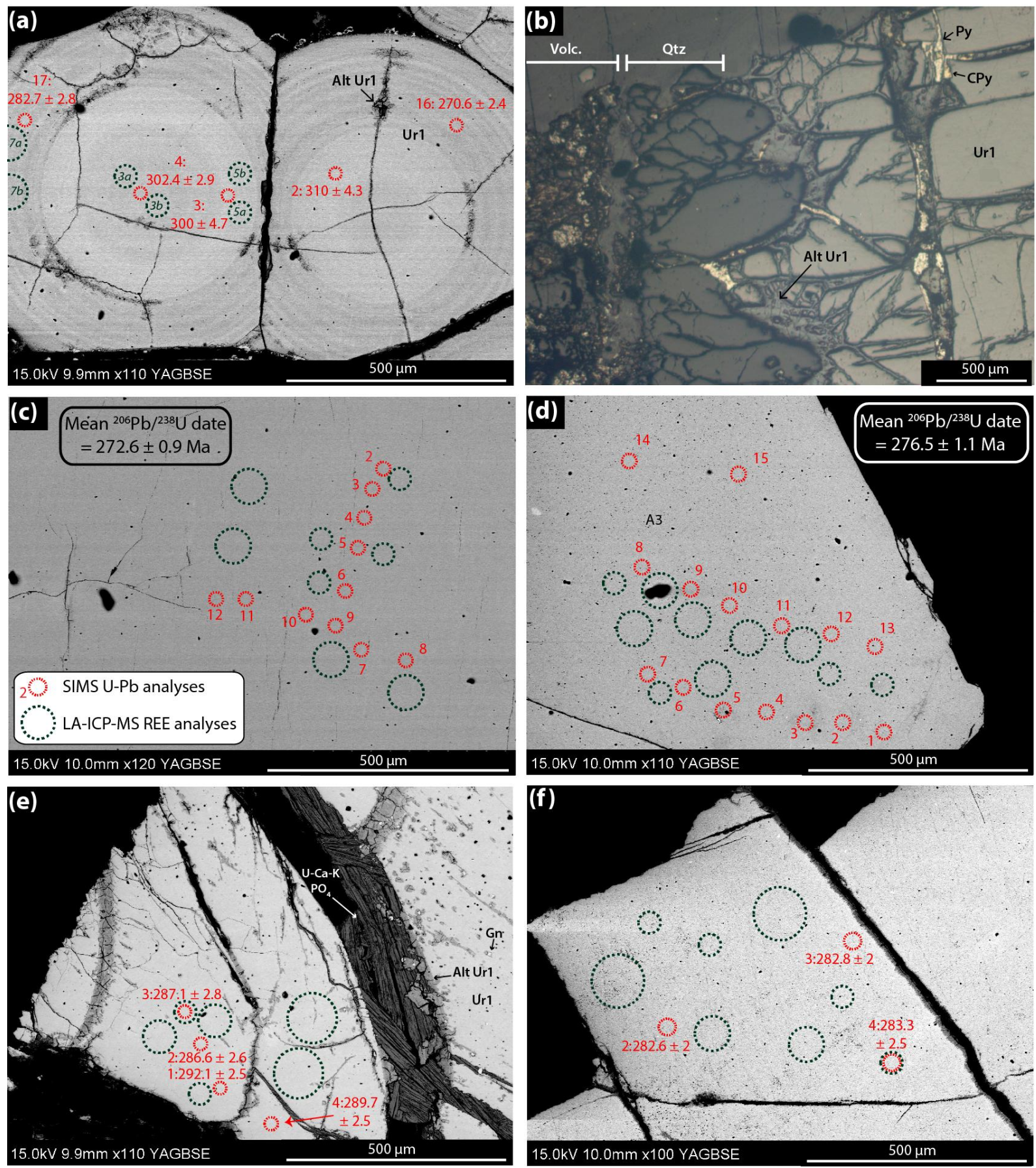

Fig. 5 
(a)
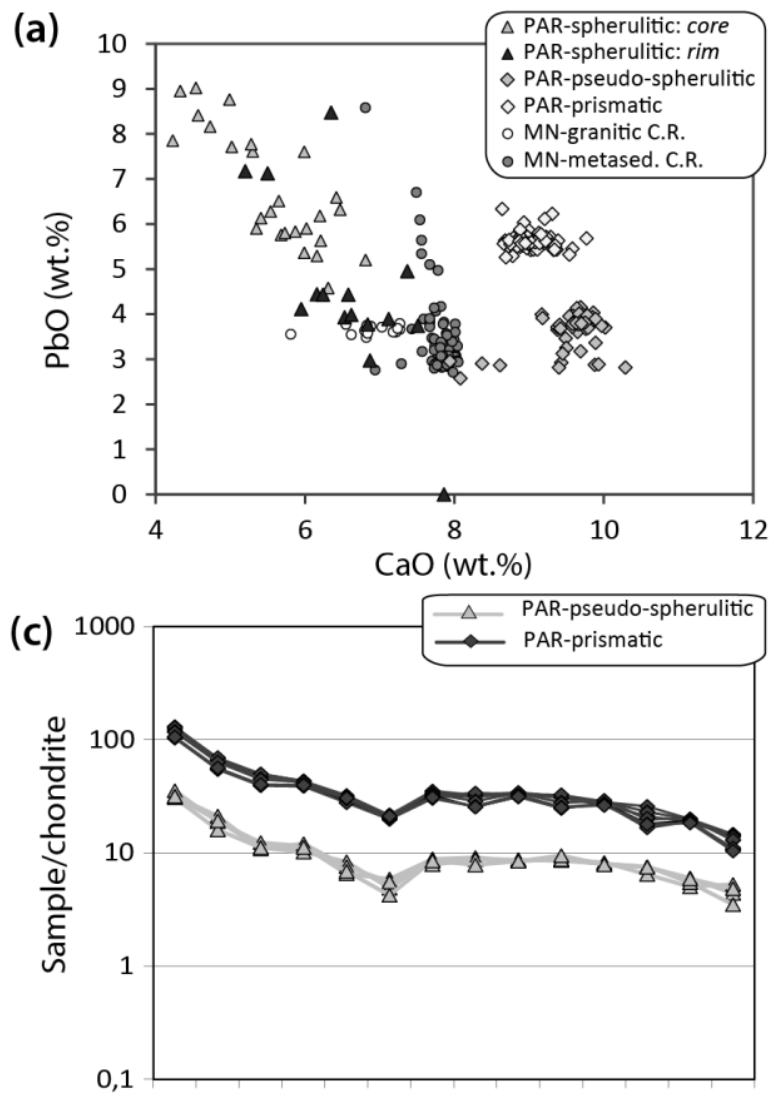

La Ce Pr NdSm Eu Gd Tb Dy Ho Er Tm Yb Lu

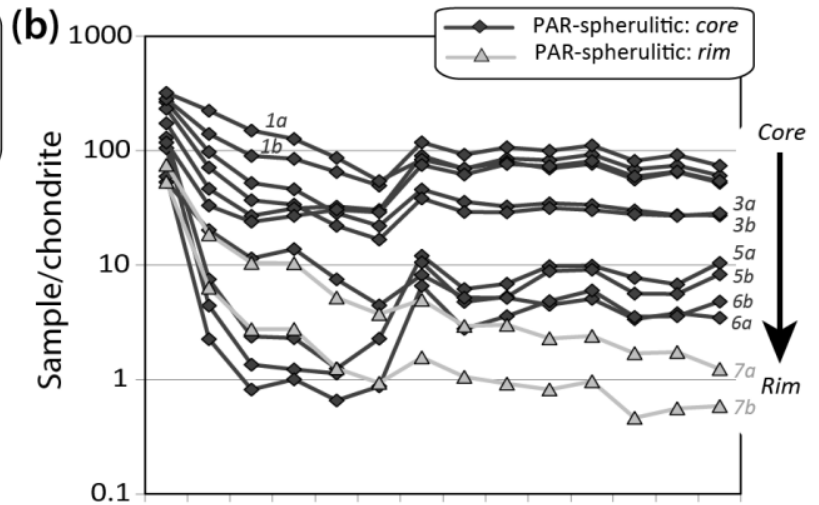

La Ce Pr Nd Sm Eu Gd Tb Dy Ho Er Tm Yb Lu

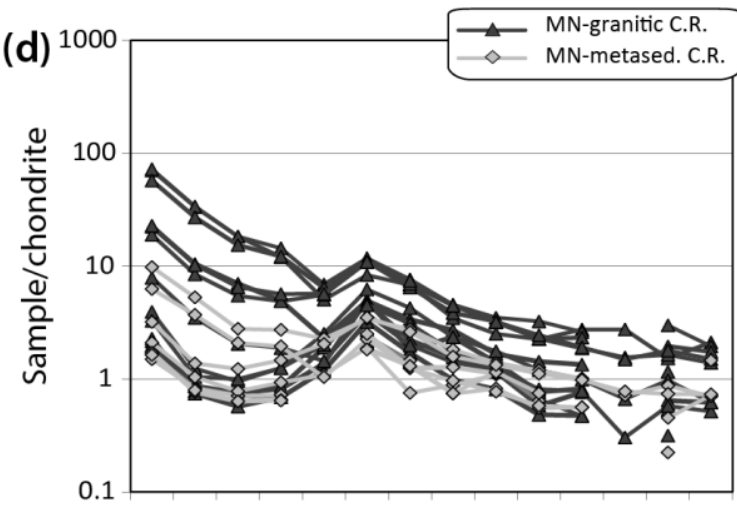

La Ce Pr Nd Sm Eu Gd Tb Dy Ho Er Tm Yb Lu

Fig. 6 

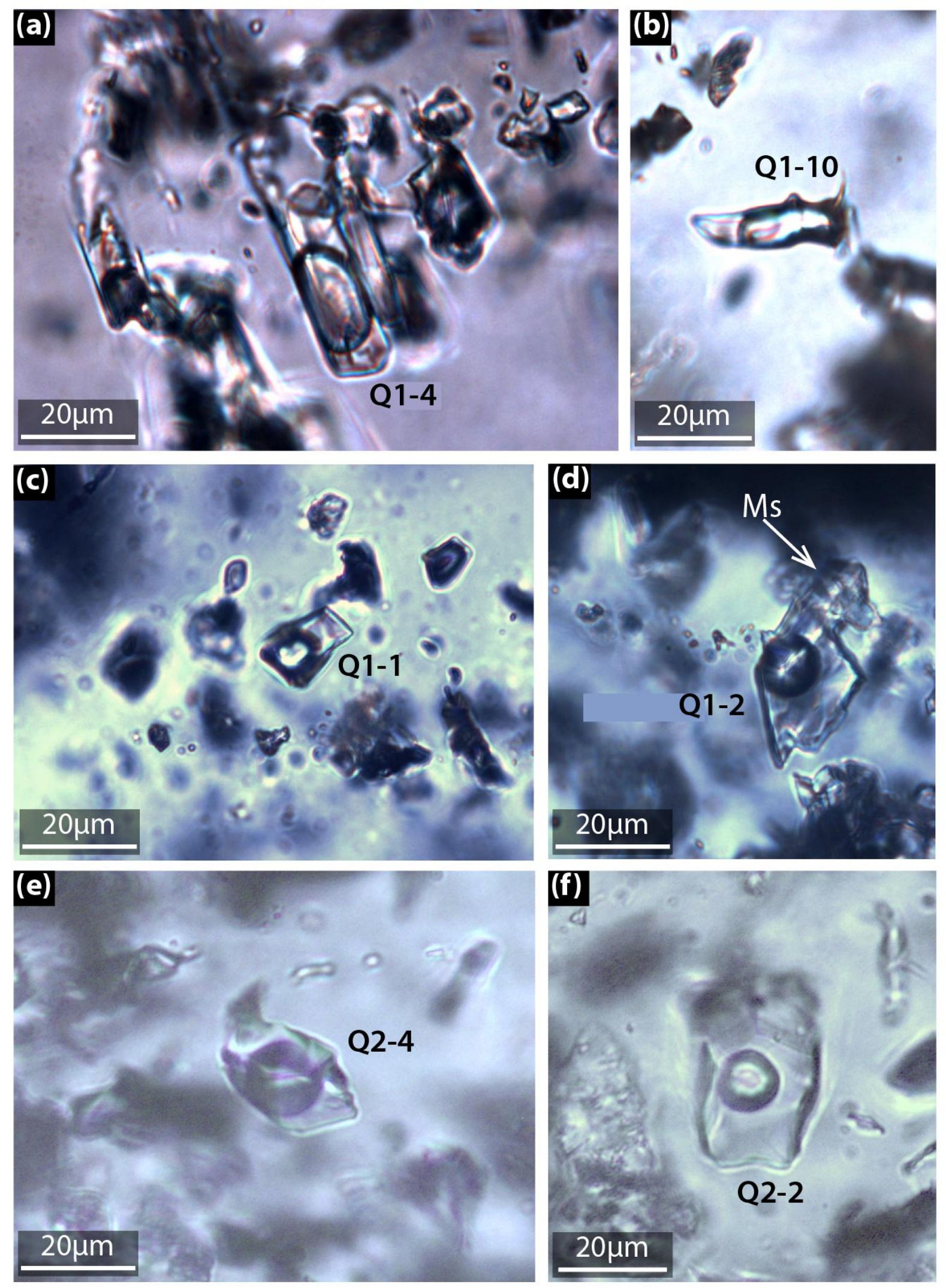

Fig. 7 
(a)

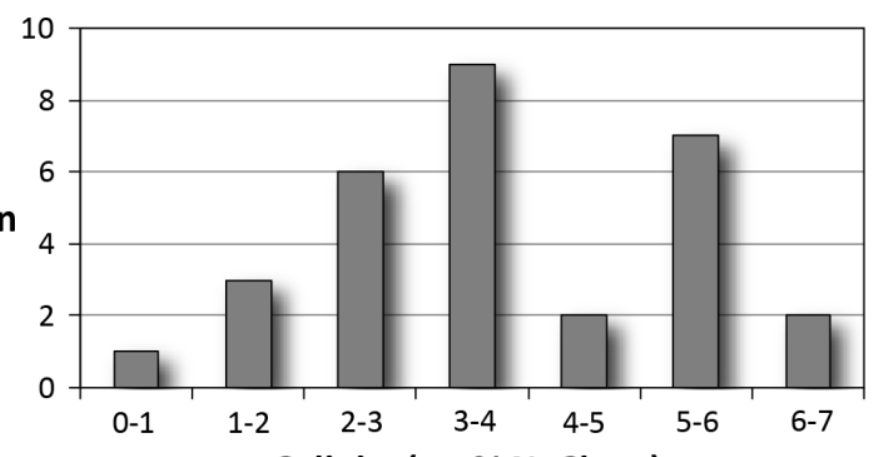

Salinity (wt.\% $\mathrm{NaCl}$ eq.)

(b)

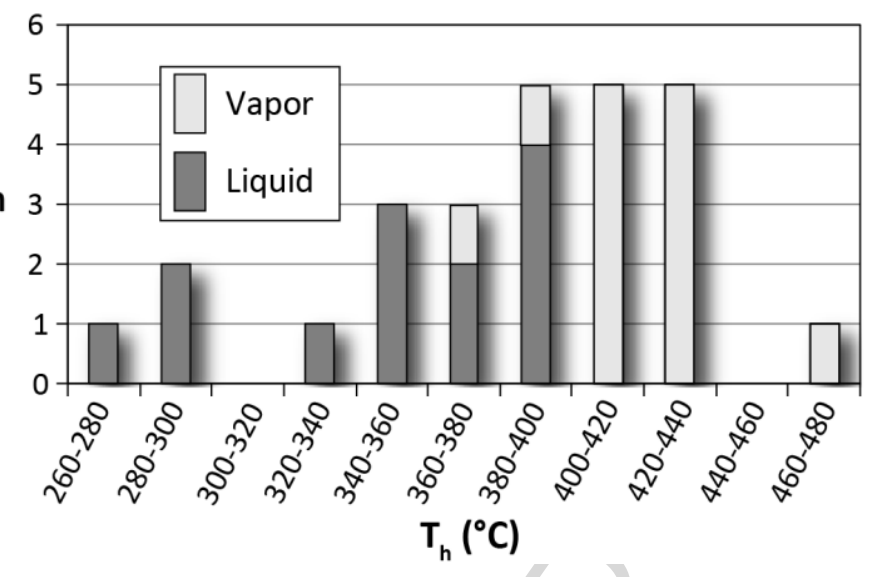

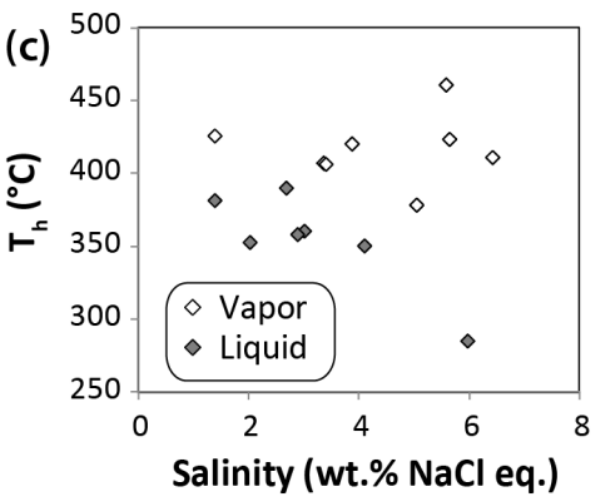

(d)

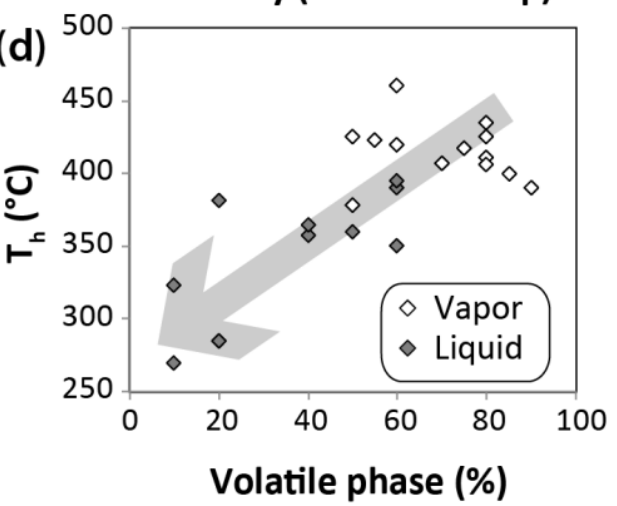

Fig. 8 

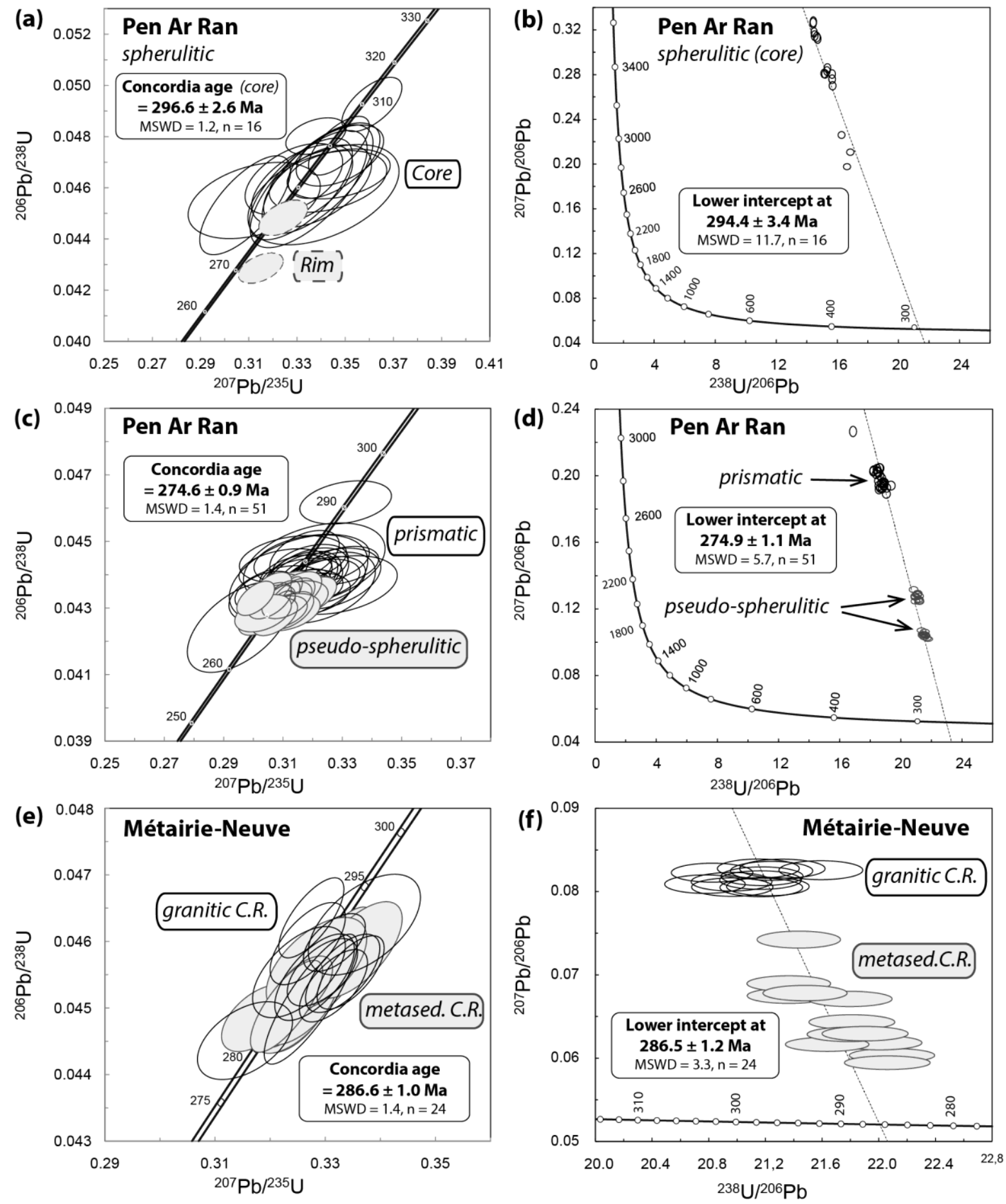

Fig. 9 


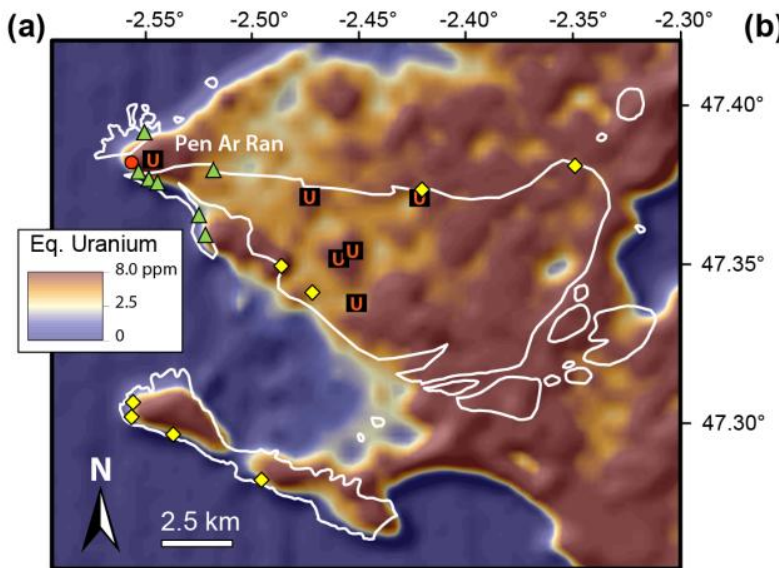

$\triangle$ Guérande granite samples (Apical zone facies)

$\diamond$ Guérande granite samples (Root and transitional facies)

- Vendée porphyroids samples

U Uranium deposit

(b) ICP-MS Spectral Gamma Ray

$\Delta$ Guérande granite (Apical zone facies) $\diamond$ Guérande granite

$\diamond$ Guérande granite (Root and trans. facies) - Vendée porphyroids (Piriac graben)

- Vendée porphyroids (Piriac graben)

- Black shales (Piriac graben)

* Vendée porphyroids (Vendée and Belle-lle)

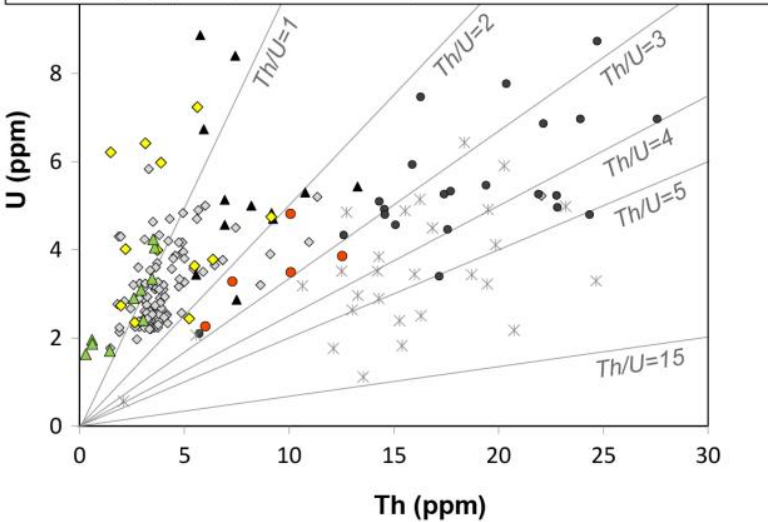

Fig. 10 

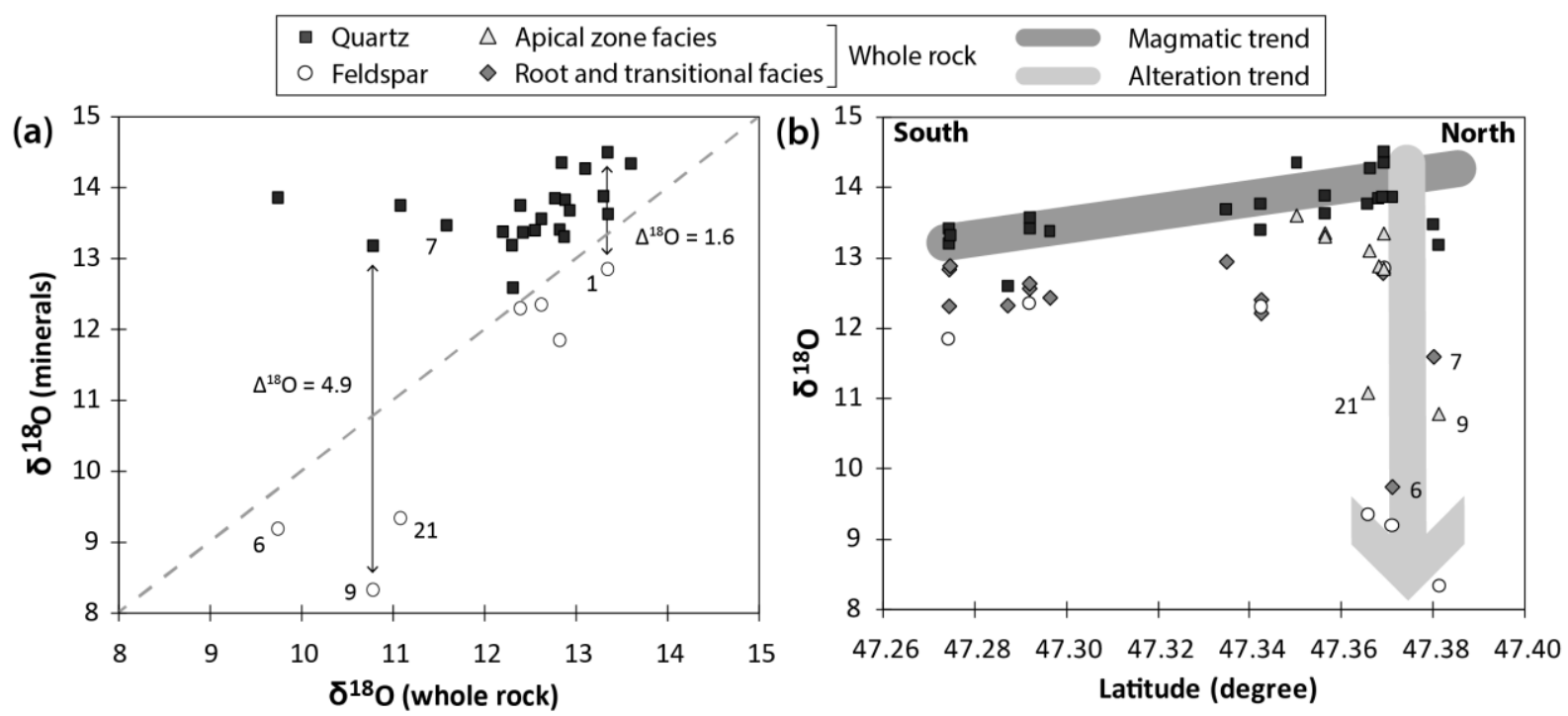

Fig. 11 

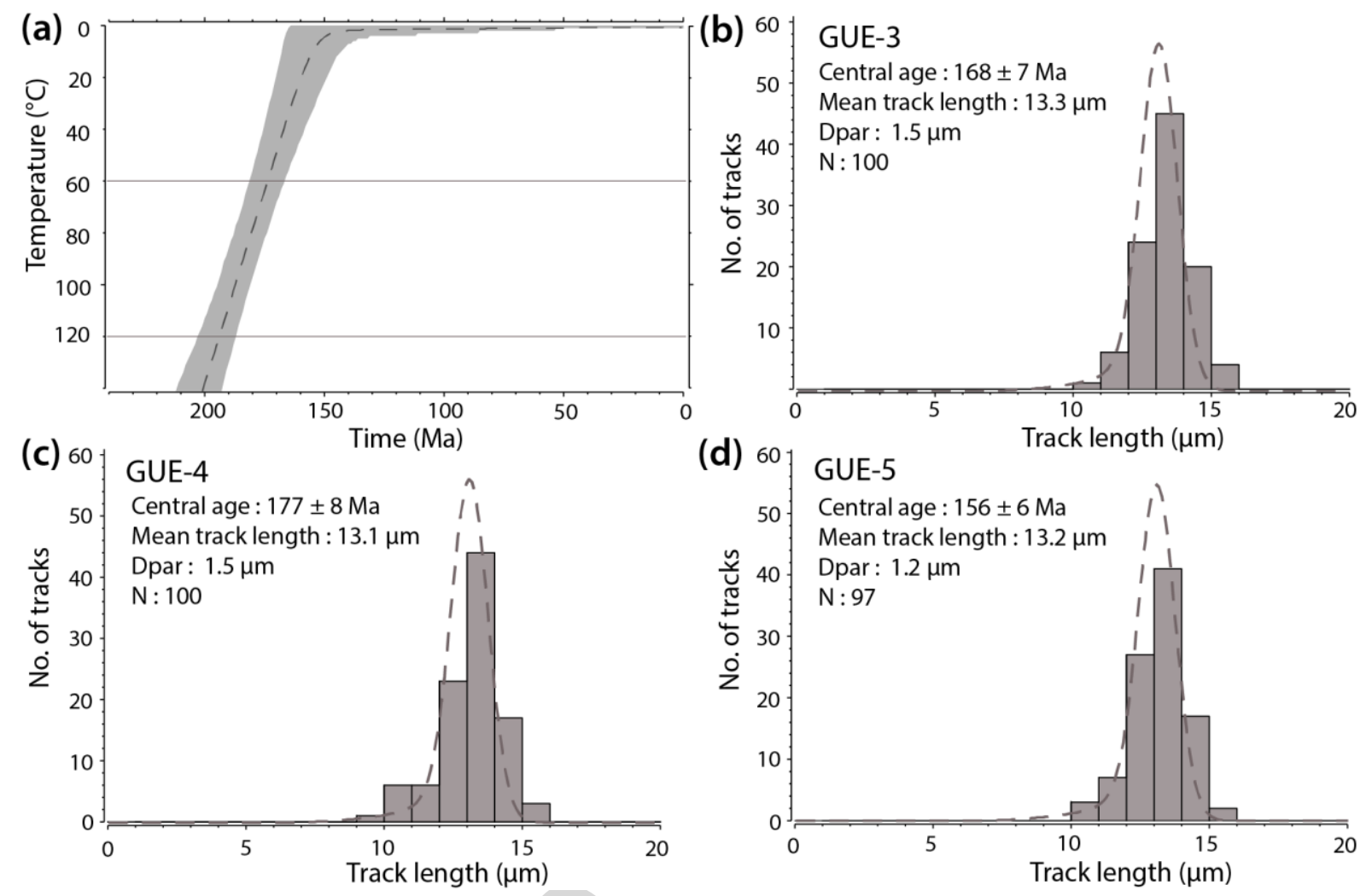

Fig. 12 

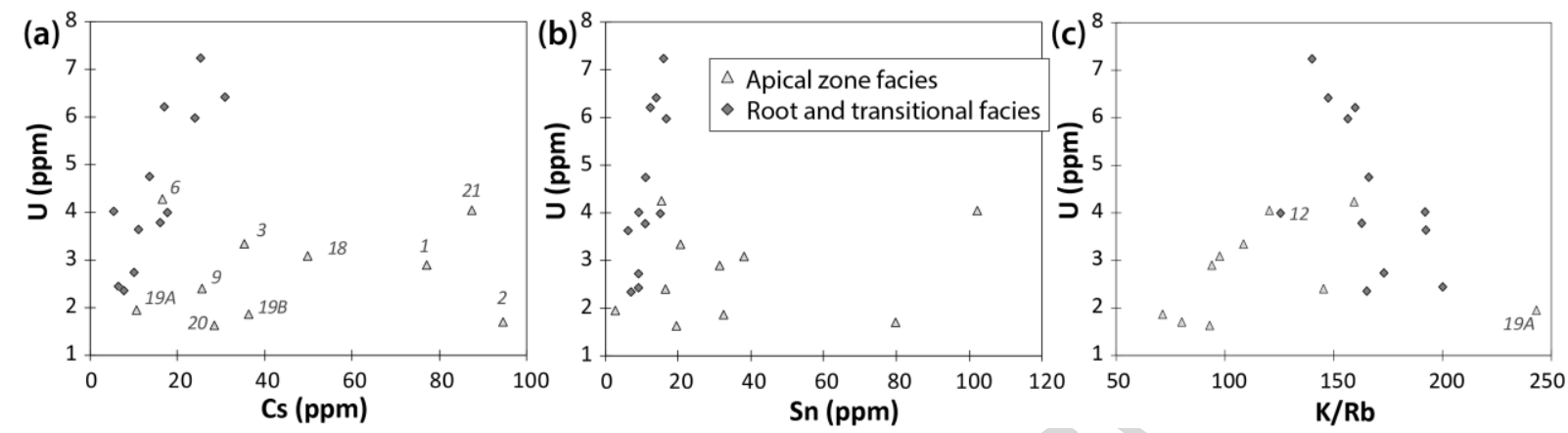

Fig. 13 
Guérande granite

undeformed Granite
$307 \pm 0.3 \mathrm{Ma} \longrightarrow$

Near surface exhumation at ca. $170 \mathrm{Ma}$ (AFT) $286.6 \pm 1 \mathrm{Ma}$

$$
\text { 它 }
$$

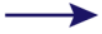

Pen Ar Ran $274.6 \pm 0.9 \mathrm{Ma}$

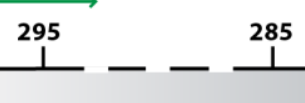
$\stackrel{285}{\perp}$

Fig. 14 

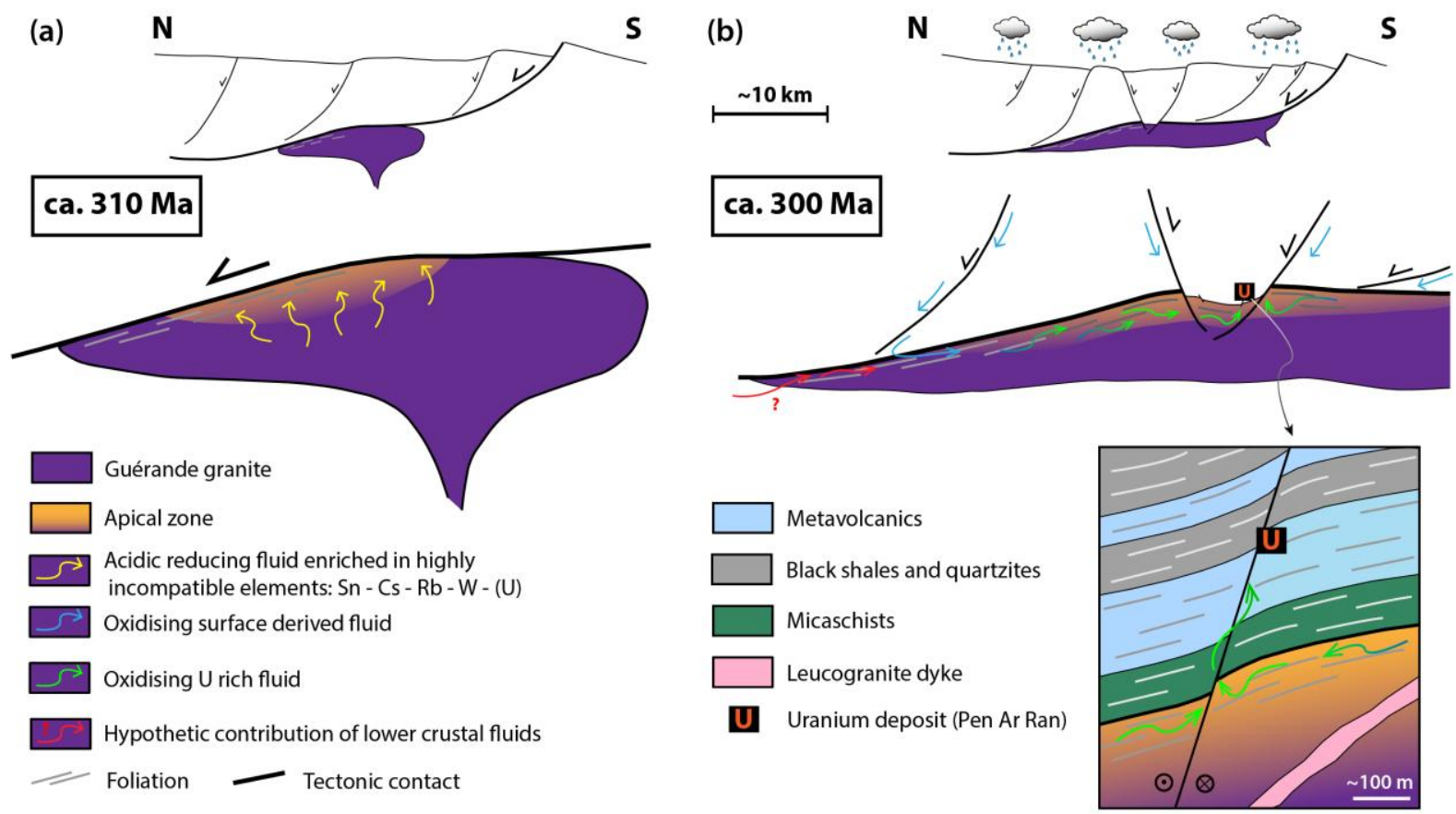

Fig. 15 


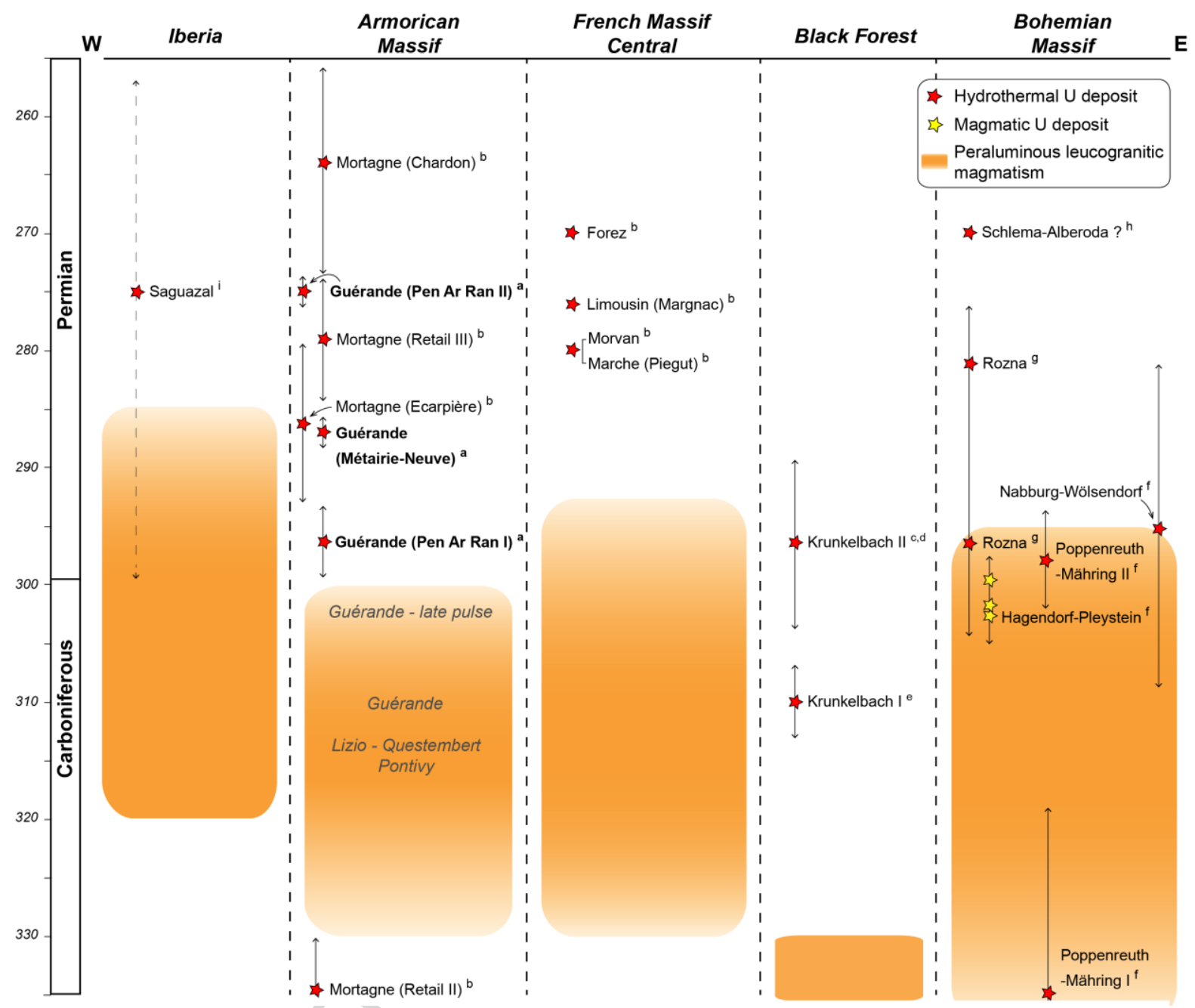

Fig. 16 
Table 1

\begin{tabular}{cccccccccc}
\hline & \multicolumn{2}{c}{$\mathbf{K}(\%)$} & \multicolumn{2}{c}{$\mathbf{U}(\mathbf{p p m})$} & \multicolumn{2}{c}{ Th $(\mathbf{p p m})$} & \multicolumn{2}{c}{ Th/U } \\
\hline \hline & $\mathrm{n}$ & Mean & $\sigma$ & Mean & $\sigma$ & Mean & $\sigma$ & Mean & $\sigma$ \\
\hline Granite & 102 & 4.3 & 0.6 & 3.3 & 1.1 & 4.6 & 5.0 & 1.3 & 0.6 \\
Metavolcanics & 22 & 6.0 & 2.0 & 5.5 & 1.5 & 18.6 & 1.5 & 3.5 & 0.8 \\
Black shales & 12 & 2.5 & 0.8 & 5.4 & 1.8 & 8.1 & 2.3 & 1.6 & 0.6 \\
\hline
\end{tabular}


Table 2

\begin{tabular}{|c|c|c|c|c|c|c|c|c|c|c|c|c|c|c|}
\hline \multirow[b]{2}{*}{ Analyses } & \multicolumn{2}{|c|}{$\begin{array}{c}\text { PAR-spherulitic: } \\
\text { Ur1 (rim) }\end{array}$} & \multicolumn{2}{|c|}{$\begin{array}{c}\text { PAR-spherulitic: } \\
\text { Ur1 (core) }\end{array}$} & \multicolumn{2}{|c|}{$\begin{array}{c}\text { PAR-spherulitic: } \\
\text { Alt Ur1 }\end{array}$} & \multicolumn{2}{|c|}{$\begin{array}{l}\text { PAR-pseudo- } \\
\text { spherulitic }\end{array}$} & \multicolumn{2}{|c|}{ PAR-prismatic } & \multicolumn{2}{|c|}{ MN-granitic C.R. } & \multicolumn{2}{|c|}{$\begin{array}{c}\text { MN-metased. } \\
\text { C.R. }\end{array}$} \\
\hline & 15 & $\sigma$ & 26 & $\sigma$ & 2 & $\sigma$ & 48 & $\sigma$ & 70 & $\sigma$ & 15 & $\sigma$ & 65 & $\sigma$ \\
\hline $\mathrm{UO}_{2}$ (wt.\%) & 82.83 & 1.60 & 82.13 & 1.39 & 71.77 & 17.56 & 82.70 & 0.79 & 80.17 & 1.90 & 84.38 & 0.83 & 84.86 & 0.99 \\
\hline $\mathrm{PbO}$ & 4.49 & 1.98 & 6.73 & 1.28 & 1.24 & 0.45 & 3.59 & 0.42 & 5.60 & 0.23 & 3.65 & 0.10 & 3.57 & 1.02 \\
\hline $\mathrm{CaO}$ & 6.58 & 0.73 & 5.57 & 0.71 & 1.67 & 0.40 & 9.55 & 0.46 & 9.17 & 1.18 & 6.88 & 0.39 & 7.77 & 0.22 \\
\hline $\mathrm{SiO}_{2}$ & 1.35 & 0.37 & 1.31 & 0.39 & 0.33 & 0.00 & 0.98 & 0.07 & 1.19 & 0.08 & 1.43 & 0.22 & 0.54 & 0.06 \\
\hline $\mathrm{FeO}$ & 0.16 & 0.10 & bdl & & 0.70 & 0.16 & bdl & & bdl & & bdl & & bdl & \\
\hline $\mathrm{P}_{2} \mathrm{O}_{5}$ & 0.14 & 0.09 & 0.13 & 0.03 & 3.06 & 0.21 & 0.23 & 0.17 & 0.21 & 0.15 & 0.13 & 0.15 & 0.17 & 0.01 \\
\hline Total & 95.55 & 1.53 & 95.87 & 0.66 & 78.76 & 18.46 & 97.06 & 0.57 & 96.34 & 1.00 & 96.47 & 0.51 & 96.90 & 0.69 \\
\hline Analyses & 4 & $\overline{\sigma \sigma}$ & 10 & $\bar{\sigma} \sigma$ & & 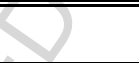 & 4 & $\bar{\sigma} \sigma$ & 10 & $\bar{\sigma} \sigma$ & 12 & $\bar{\sigma} \sigma$ & 8 & $\bar{\sigma} \sigma$ \\
\hline$\Sigma$ REE & 24.35 & 9.62 & 145.39 & 118.99 & & & 33.89 & 1.77 & 119.82 & 8.65 & 18.26 & 18.66 & 3.66 & 2.56 \\
\hline $\mathrm{Eu} / \mathrm{Eu}^{*}$ & 0.4 & 0.4 & 0.5 & 0.2 & & & 0.7 & 0.1 & 0.7 & 0.0 & 1.6 & 0.3 & 2.0 & 0.5 \\
\hline $\mathrm{LaN} / \mathrm{SmN}$ & 782.0 & 1456.6 & 33.3 & 43.6 & & & 4.5 & 0.7 & 3.9 & 0.3 & 3.5 & 2.1 & 5.3 & 4.4 \\
\hline La & 15.13 & 2.21 & 41.23 & 22.70 & & & 7.69 & 0.49 & 27.66 & 2.60 & 5.65 & 6.45 & 0.83 & 0.71 \\
\hline $\mathrm{Ce}$ & 5.67 & 3.85 & 39.60 & 43.87 & & & 11.55 & 1.31 & 38.03 & 3.75 & 6.72 & 7.95 & 1.12 & 1.05 \\
\hline $\operatorname{Pr}$ & 0.40 & 0.38 & 3.67 & 4.42 & & & 1.06 & 0.06 & 4.12 & 0.39 & 0.60 & 0.65 & 0.11 & 0.08 \\
\hline $\mathrm{Nd}$ & 1.79 & 2.00 & 16.80 & 18.56 & & & 5.14 & 0.36 & 18.85 & 0.78 & 2.32 & 2.31 & 0.56 & 0.35 \\
\hline Sm & 0.26 & 0.35 & 4.08 & 4.26 & & & 1.09 & 0.12 & 4.47 & 0.19 & 0.52 & 0.32 & 0.24 & 0.09 \\
\hline Eu & 0.13 & 0.11 & 1.31 & 1.10 & & & 0.29 & 0.04 & 1.18 & 0.04 & 0.40 & 0.18 & 0.14 & 0.04 \\
\hline Gd & 0.38 & 0.42 & 9.71 & 8.06 & & & 1.70 & 0.09 & 6.46 & 0.32 & 0.89 & 0.48 & 0.32 & 0.14 \\
\hline Tb & 0.06 & 0.04 & 1.36 & 1.20 & & & 0.31 & 0.02 & 1.05 & 0.12 & 0.10 & 0.05 & 0.04 & 0.02 \\
\hline Dy & 0.30 & 0.30 & 10.60 & 9.83 & & & 2.11 & 0.03 & 8.10 & 0.29 & 0.51 & 0.24 & 0.27 & 0.05 \\
\hline Ho & 0.06 & 0.06 & 2.29 & 1.98 & & & 0.49 & 0.02 & 1.54 & 0.17 & 0.08 & 0.05 & 0.04 & 0.02 \\
\hline $\mathrm{Er}$ & 0.27 & 0.16 & 7.28 & 6.52 & & & 1.29 & 0.03 & 4.44 & 0.17 & 0.23 & 0.13 & 0.12 & 0.04 \\
\hline $\mathrm{Tm}$ & 0.02 & 0.02 & 0.85 & 0.74 & & & 0.18 & 0.01 & 0.50 & 0.07 & 0.03 & 0.02 & 0.02 & 0.00 \\
\hline $\mathrm{Yb}$ & 0.10 & 0.12 & 5.96 & 5.44 & & & 0.90 & 0.07 & 3.11 & 0.10 & 0.20 & 0.13 & 0.09 & 0.05 \\
\hline
\end{tabular}


Table 3

\begin{tabular}{|c|c|c|c|c|c|c|c|c|c|}
\hline \multirow[b]{2}{*}{ Inclusion } & \multirow{2}{*}{$\begin{array}{c}\text { Homogenization } \\
\text { Type }\end{array}$} & \multirow{2}{*}{$\begin{array}{c}\text { Degree } \\
\text { of } \\
\text { volatile } \\
\text { filling } \\
\text { (\%) } \\
\end{array}$} & \multicolumn{2}{|c|}{ Microthermometry $\left({ }^{\circ} \mathrm{C}\right)$} & \multicolumn{2}{|c|}{ Salinity (wt.\% $\mathrm{NaCl}$ eq.) } & \multicolumn{3}{|c|}{ Volatile phase (mol.\%) } \\
\hline & & & Tm Ice & Th & Microthermometry & Raman & $\mathrm{O}_{2}$ & $\mathbf{N}_{\mathbf{2}}$ & $\mathrm{H}_{2}$ \\
\hline Q1-1 & Vapor & 60 & -2.4 & 420 & 4.0 & 3.8 & 74.9 & 3.0 & 22.1 \\
\hline Q1-6 & Liquid & 20 & -3.5 & 285 & 5.6 & 6.3 & 78.3 & 2.0 & 19.7 \\
\hline Q1-9 & Liquid & 60 & -1.4 & 390 & 2.4 & 3.0 & 39.0 & 14.0 & 47.0 \\
\hline Q1-13 & Vapor & 60 & -3.7 & 461 & 5.9 & 5.2 & 79.8 & 1.1 & 19.1 \\
\hline Q1-16 & Vapor & 70 & & 407 & & 3.4 & 71.7 & 2.6 & 25.7 \\
\hline Q2-2 & Liquid & 20 & -1.2 & 353 & 2.0 & 2.0 & 60.8 & 6.2 & 33.0 \\
\hline Q2-3 & Vapor & 80 & & 406 & & 3.4 & 67.0 & 9.0 & 24.0 \\
\hline Q2-4 & Liquid & 50 & -1.7 & 360 & 2.9 & 3.1 & 65.5 & 3.3 & 31.2 \\
\hline Q2-5 & Liquid & 60 & & 350 & & 4.1 & 45.0 & 9.0 & 46.0 \\
\hline
\end{tabular}


Table 4

\begin{tabular}{|c|c|c|c|c|c|c|}
\hline Sample & location & $\delta{ }^{18} 0$ & $\delta{ }^{18} \mathrm{O}$ & $\delta{ }^{18} 0$ & $\underset{\text { Fds) }}{\Delta_{(\mathrm{Qtz}-}}$ & $\begin{array}{l}\mathbf{T}_{\text {(Qtz- }} \\
\text { Fds) }\end{array}$ \\
\hline & & WR & Qtz & Fds & & \\
\hline GUE-1 & Apex & 13.3 & 14.5 & 12.9 & 1.6 & 408 \\
\hline GUE-2 & Apex & 12.8 & 14.4 & & & \\
\hline GUE-3 & Apex & 12.9 & 13.8 & & & \\
\hline GUE-4 & Root & 12.4 & 13.8 & 12.3 & 1.5 & 509 \\
\hline GUE-5 & Root & 12.2 & 13.4 & & & \\
\hline GUE-6 & Apex & 9.7 & 13.9 & 9.2 & 4.7 & 74 \\
\hline GUE-7 & Root & 11.6 & 13.5 & & & \\
\hline GUE-8 & Root & 12.8 & 13.9 & & & \\
\hline GUE-9 & Apex & 10.8 & 13.2 & 8.3 & 4.9 & 65 \\
\hline GUE-10 & Root & 12.9 & 13.7 & & & \\
\hline GUE-11 & Root & 12.8 & 13.4 & 11.9 & & \\
\hline GUE-12 & Root & 12.3 & 13.2 & & & \\
\hline GUE-13 & Root & 12.9 & 13.3 & & & \\
\hline GUE-14 & Root & 12.4 & 13.4 & & & \\
\hline GUE-15 & Root & 12.6 & 13.6 & 12.4 & & 599 \\
\hline GUE-16 & Root & 12.6 & 13.4 & & & \\
\hline GUE-17 & Root & 12.3 & 12.6 & & & \\
\hline GUE-18 & Apex & 13.6 & 14.3 & & & \\
\hline GUE-19.A & Apex & 13.4 & 13.6 & & & \\
\hline GUE-19.B & Apex & 13.3 & 13.9 & & & \\
\hline GUE-20 & Apex & 13.1 & 14.3 & & & \\
\hline GUE-21 & Apex & 11.1 & 13.8 & 9.3 & 4.4 & 89 \\
\hline
\end{tabular}

* Temperature calulation $\left({ }^{\circ} \mathrm{C}\right)$ following the calibration of Zheng (1993) 
Table 5

\begin{tabular}{|c|c|c|c|c|c|c|c|c|c|c|c|}
\hline Sample & $\begin{array}{c}\text { Number } \\
\text { of } \\
\text { grains } \\
\end{array}$ & $\rho d \times 10^{5}\left(\mathrm{~cm}^{2}\right)$ & $\begin{array}{c}\rho s \times 10^{5} \\
\left(\mathrm{~cm}^{2}\right)\end{array}$ & $\begin{array}{c}\rho \mathrm{i} \times 10^{5} \\
\left(\mathrm{~cm}^{2}\right)\end{array}$ & $\begin{array}{c}U \\
(\mathrm{ppm})\end{array}$ & $P\left(x^{2}\right)$ & $\begin{array}{c}\text { Age } \\
\text { (Ma) }\end{array}$ & $\pm 2 \sigma$ & MTL & SD & $D_{\text {par }}$ \\
\hline GUE-3 & 20 & 3.409 (6127) & $\begin{array}{l}35.998 \\
(4579)\end{array}$ & $\begin{array}{c}12.17 \\
(1548)\end{array}$ & 44 & 33.4 & 168 & 7 & 13.39 & 0.96 & 1.5 \\
\hline & & & 56.923 & 18.411 & & & & & & & \\
\hline GUE-4 & 20 & $3.457(4485)$ & (3404) & $(1081)$ & 61 & 97.4 & 177 & 8 & 13.16 & 1.11 & 1.46 \\
\hline GUE-5 & 20 & 3.361 (5510) & $\begin{array}{l}55.589 \\
(4058)\end{array}$ & $\begin{array}{c}19.89 \\
(1452)\end{array}$ & 69 & 35.2 & 156 & 6 & 13.22 & 0.99 & 1.19 \\
\hline
\end{tabular}



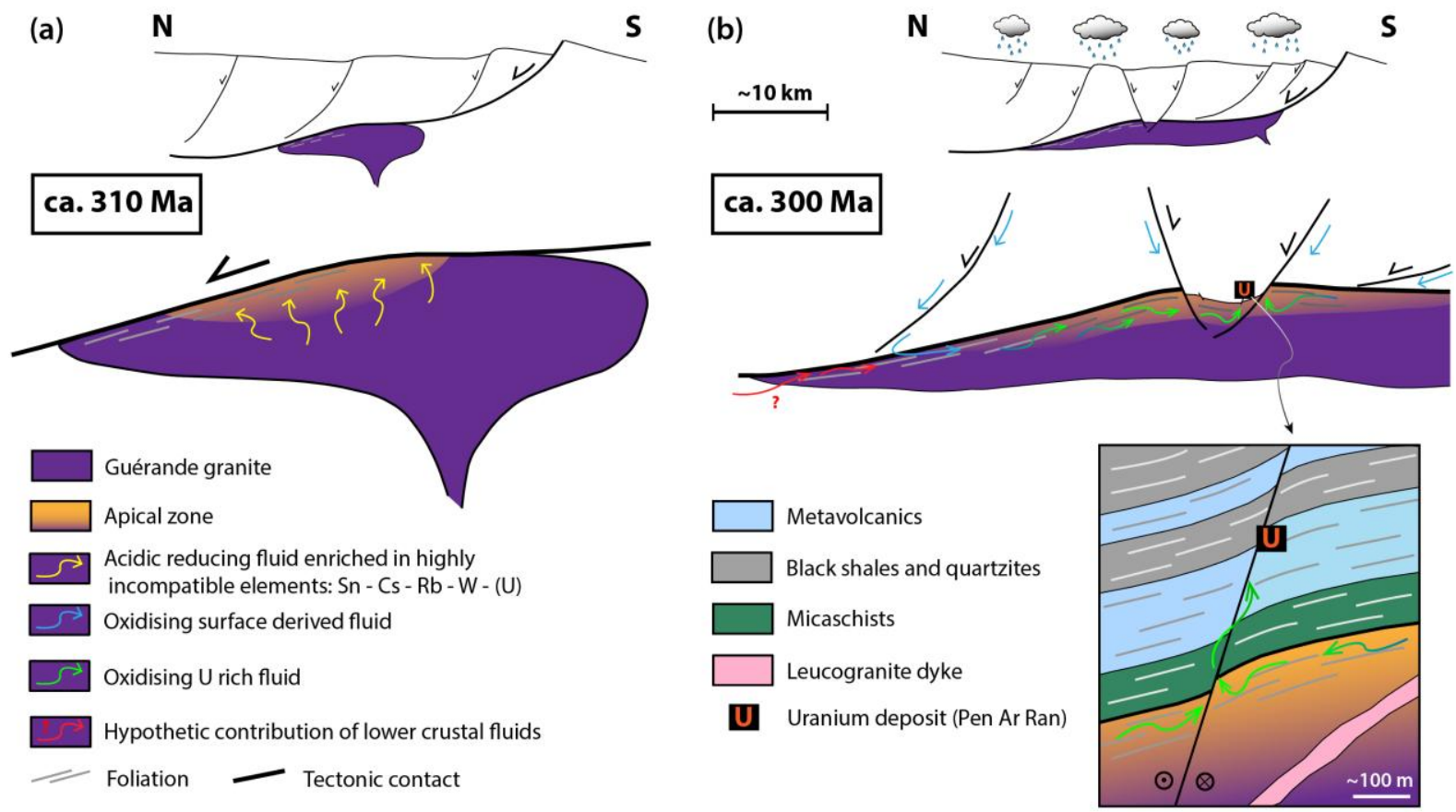

Graphical abstract 


\section{Highlights:}

- The apex of the Guérande leucogranite is structurally located below an U deposit.

- Leaching of U likely occurred at the apical zone of the intrusion.

- Sub-solidus alteration with meteoric fluids affected the deformed facies at the apex.

- Hydrothermal circulation in the granite is sub-synchronous with $U$ mineralization.

- The Guérande leucogranite is proposed as the main source for the $U$ of the deposit. 